\title{
Protective Clothing Based on Permselective Membrane and Carbon Adsorption
}

\author{
Final Topical Report \\ June 25, 1993 - June 24, 1996 \\ By \\ D. L. Gottschlich; R. W. Baker \\ C. G. Casillas; J. F. Davidson; I. Pinnau
}

Work Performed Under Contract No.: DE-AC21-93MC30179

For

U.S. Department of Energy

Office of Fossil Energy

Federal Energy Technology Center

P.O. Box 880

Morgantown, West Virginia 26507-0880

RECENEO

MAR O 21999

OSTI

By

Membrane Technology and Research, Inc.

1360 Willow Road

Suite 103

Menlo Park, California 94025 


\section{Disclaimer}

This report was prepared as an account of work sponsored by an agency of the United States Government. Neither the United States Government nor any agency thereof, nor any of their employees, makes any warranty, express or implied, or assumes any legal liability or responsibility for the accuracy, completeness, or usefulness of any information, apparatus, product, or process disclosed, or represents that its use would not infringe privately owed rights. Reference herein to any specific commercial product, process, or service by trade name, trademark, manufacturer, or otherwise does not necessarily constitute or imply its endorsement, recommendation, or favoring by the United States Government or any agency thereof. The views and opinions of authors expressed herein do not necessarily state or reflect those of the United States Government or any agency thereof. 


\section{DISCLAIMER}

Portions of this document may be illegible in electronic image products. Images are produced from the best available original document. 


\begin{abstract}
The goal of this project is to develop chemical protective clothing for use by DOE decontamination and decommissioning workers that will increase worker productivity-because it is cooler and more comfortable than conventional protective clothing - while maintaining protection against chemical liquids and vapors.

This report describes the results from Phase I of a two-phase project to complete development of a new protective material and to demonstrate its utility in field trials at DOE sites. The fabric is based on a permselective membrane that is freely permeable to water but essentially impermeable to toxic organic vapors. In the first phase, the fabric properties were improved by modifying both the materials and the preparation procedure used to form the membrane. Production of the fabric was then scaled up to use commercial-scale production machinery. A small number of prototype suits were made, and a preliminary suit evaluation was conducted. In Phase II, current plans are to produce 300-400 suits for a complete laboratory and field demonstration program.
\end{abstract}

The fabrics produced during this project were a significant advancement in state-of-the-art protective fabrics. No currently available fabrics combine protection against vapor and liquid chemical hazards while minimizing the potential for heat stress by allowing water vapor to permeate the fabric. The fabrics developed in this project meet the water transmission rate goals (greater than $800 \mathrm{~g} / \mathrm{m}^{2}$.day) and provide chemical protection equivalent to currently used non-water-vaporpermeable (occlusive) chemical protective suits. These results were achieved in a practical fabric that is strong, durable, flexible, lightweight, and easy to manufacture into a suit. A cost-benefit calculation, based on the improvement in worker productivity achieved with MTR water-vaporpermeable suits over a conventional occlusive suit, shows that the MTR suits are cost effective only if used for two days or more. However, small and achievable improvement in the fabric properties and reductions in production cost as the process is scaled up would make MTR's water-permeable suits cost effective even when exchanged daily. 


\section{TABLE OF CONTENTS}

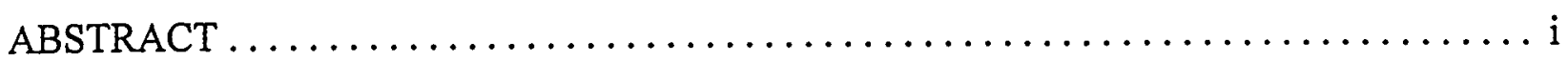

1. EXECUTIVE SUMMARY $\ldots \ldots \ldots \ldots \ldots \ldots \ldots \ldots \ldots \ldots \ldots \ldots \ldots \ldots \ldots \ldots \ldots$

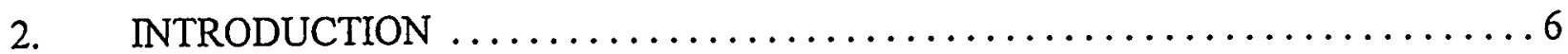

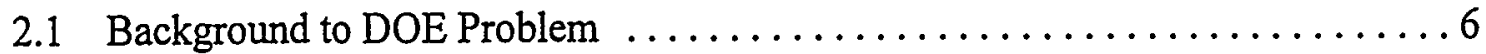

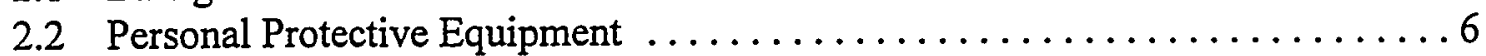

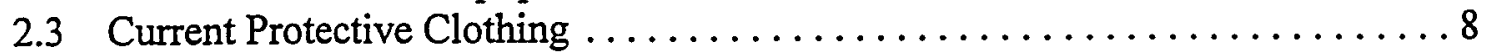

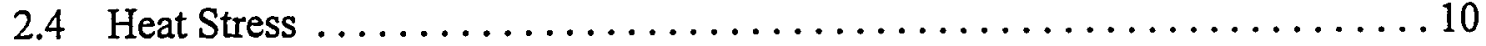

2.5 Background to MTR's Protective Clothing Technology $\ldots \ldots \ldots \ldots \ldots \ldots 13$

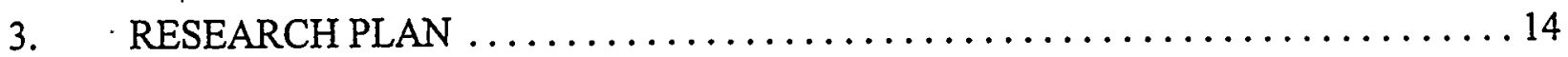

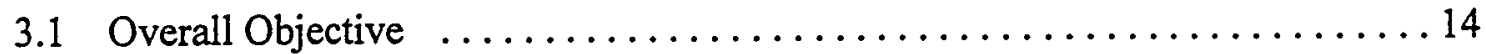

3.2 Performance Goals . . . . . . . . . . . . . . . . . . . . . . . . . 15

3.3 Outline of Phase I Research Plan .......................

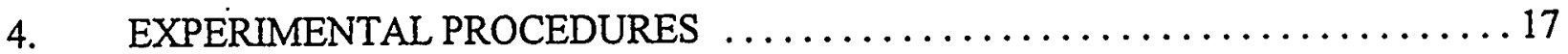

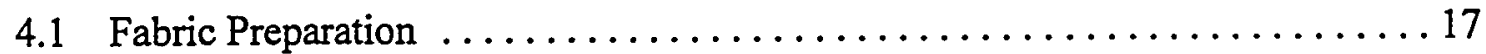

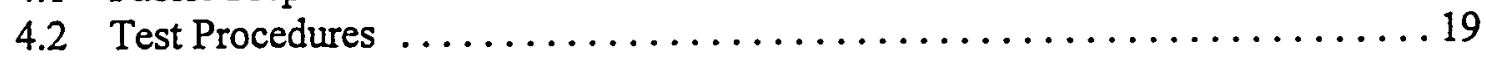

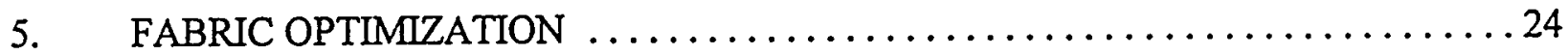

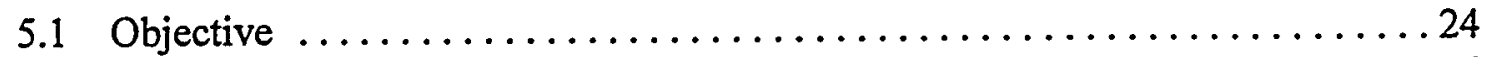

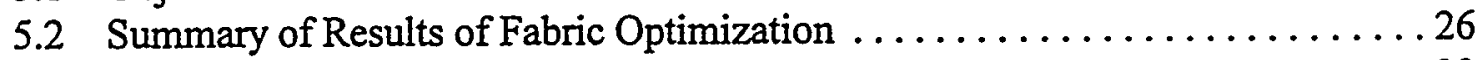

5.3 Details of Fabric Optimization Process . . . . . . . . . . . . . . . . . 29

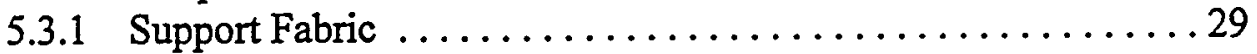

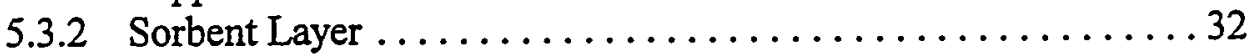

5.3.3 Permselective Layer $\ldots \ldots \ldots \ldots \ldots \ldots \ldots \ldots \ldots \ldots \ldots \ldots$

5.3.4 Protective Layer .......................... 49

6. COMMERCIAL-SCALE FABRIC PRODUCTION $\ldots \ldots \ldots \ldots \ldots \ldots \ldots \ldots \ldots$

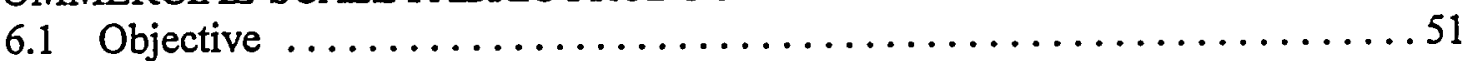

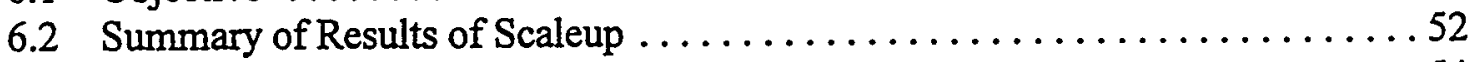

6.3 Details of Scaleup Process . . . . . . . . . . . . . . . . . . . . . 54

7. PROTOTYPE SUIT PRODUCTION AND EVALUATION $\ldots \ldots \ldots \ldots \ldots \ldots \ldots 7$

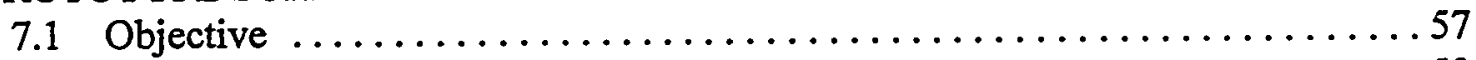

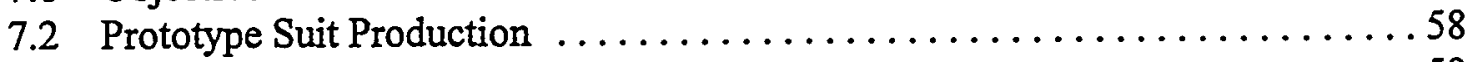

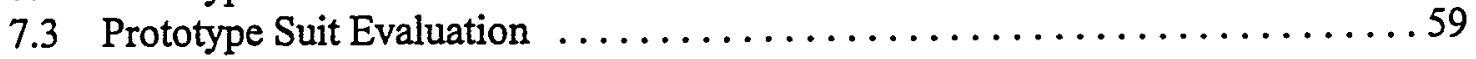

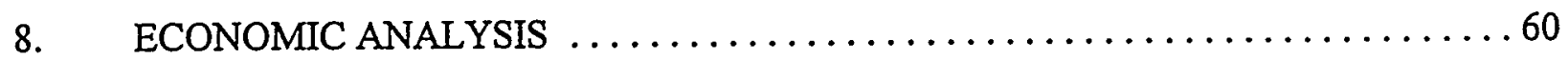


TABLE OF CONTENTS - CONTINUED

9. CONCLUSIONS AND RECOMMENDATIONS $\ldots \ldots \ldots \ldots \ldots \ldots \ldots \ldots$

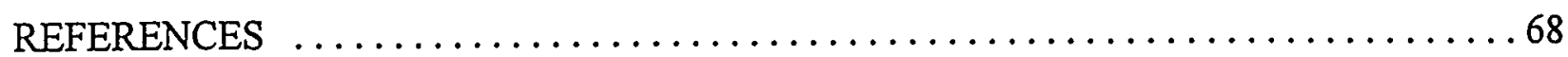

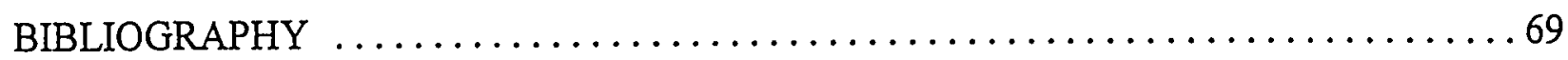

APPENDIX A: $\quad$ FABRIC EVALUATION TEST PROCEDURES . ............ A-1

APPENDIX B: CHEMICAL RESISTANCE OF PROTECTIVE CLOTHNG

MATERIALS ...........................

APPENDIX C: $\quad$ PROPERTIES OF AIRVOL POLYVINYL ALCOHOL (PVA) ..... C-1

APPENDIX D: $\quad$ SEMS FOR FABRICS PREPARED WITH VARIOUS POLYVINYL ALCOHOL (PVA) SELECTIVE LAYERS ............. D-1

APPENDIX E: $\quad$ FABRIC TEST REPORTS $\ldots \ldots \ldots \ldots \ldots \ldots \ldots \ldots \ldots \ldots . \ldots \ldots \ldots$

APPENDIX F: $\quad$ SUIT EVALUATION REPORTS $\ldots \ldots \ldots \ldots \ldots \ldots \ldots \ldots \ldots$ F-1 


\section{LIST OF FIGURES}

Figure 1. Structure of MTR-2 protective clothing fabric $\ldots \ldots \ldots \ldots \ldots \ldots \ldots \ldots$

Figure 2. Water vapor permeability and protective characteristics of commercially

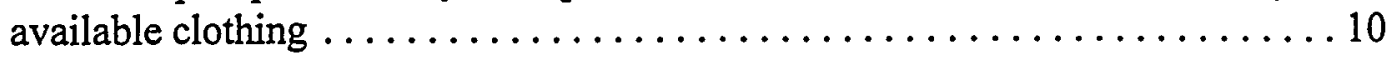

Figure 3. Heat stress exposure limits recommended by the American Conference of Government Industrial Hygienists (ACGIH) $\ldots \ldots \ldots \ldots \ldots \ldots \ldots \ldots \ldots \ldots \ldots \ldots \ldots$

Figure 4. Effect of clothing type on heat stress exposure limits (under moderate work

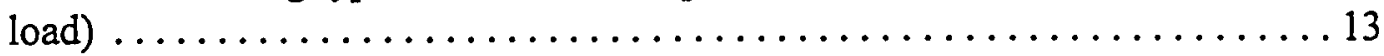

Figure 5. MTR's protective clothing concept $\ldots \ldots \ldots \ldots \ldots \ldots \ldots \ldots \ldots \ldots \ldots \ldots \ldots \ldots \ldots$

Figure 6. Schematic of the membrane casting machine used to prepare the carbon-loaded microporous membrane on support fabric $\ldots \ldots \ldots \ldots \ldots \ldots \ldots \ldots \ldots \ldots$

Figure 7. Schematic of a thin-film coating machine $\ldots \ldots \ldots \ldots \ldots \ldots \ldots \ldots \ldots$

Figure 8. Diagram of apparatus for testing permeation resistance $\ldots \ldots \ldots \ldots \ldots \ldots 21$

Figure 9. Diagram of gas permeation apparatus for testing composite fabrics $\ldots \ldots \ldots 22$

Figure 10. Structure of MTR-2 protective clothing fabric $\ldots \ldots \ldots \ldots \ldots \ldots \ldots \ldots \ldots$

Figure 11. Schematic of manufacturing steps for protective fabric $\ldots \ldots \ldots \ldots \ldots 28$

Figure 12. Effect of sorbent content on moisture vapor transmission rate (MVTR) . . . . 37

Figure 13. Moisture vapor transmission rate (MVTR) through the four short-listed fabric

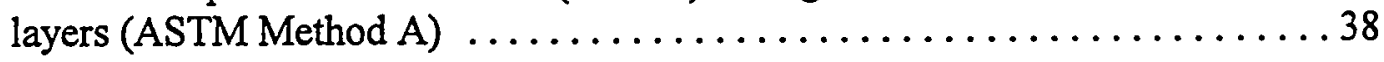

Figure 14. SEM of $8 \%$ polyvinyl alcohol (PVA) on Kynar 761: carbon sorbent layer with

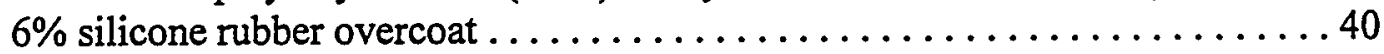

Figure 15. Effect of molecular weight and degree of hydrolysis on physical and chemical

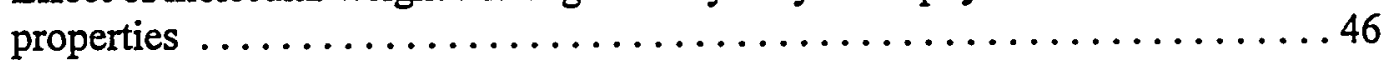

Figure 16. Schematic showing crosslinking of polyvinyl alcohol (PVA) by chemical and

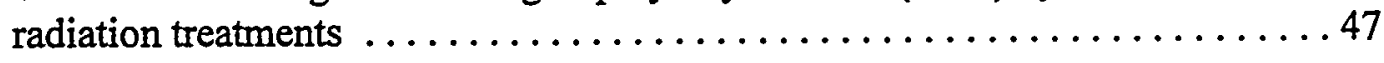

Figure 17. Schematic of laminating procedure used by Uretek $\ldots \ldots \ldots \ldots \ldots \ldots \ldots$

Figure 18. Full-body coverall style used for prototype suits ................. 59 


\section{LIST OF TABLES}

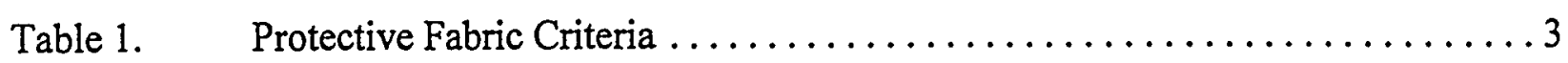

Table 2. Properties of MTR and Commercially Available Protective Fabrics ........5

Table 3. EPA Levels of Chemical Protective Clothing $\ldots \ldots \ldots \ldots \ldots \ldots$

Table 4. Issues to be Resolved During Technology Development $\ldots \ldots \ldots \ldots \ldots$

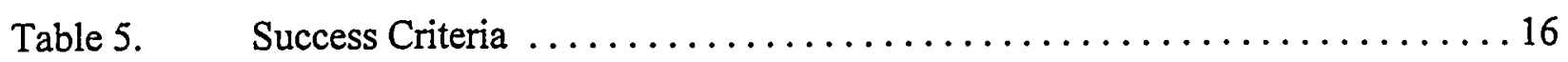

Table 6. Tests Used to Evaluate Fabric and Clothing $\ldots \ldots \ldots \ldots \ldots \ldots \ldots$

Table 7. Reasons for Using Dichloromethane as Challenge Chemical ........... 20

Table 8. Grading System Used to Rate Mechanical Properties of Coated Fabrics . . . . 23

Table 9. Fabric Components Studied During the Fabric Optimization Process. . . . . . 25

Table 10. Summary of Finalized Protective Fabric Materials $\ldots \ldots \ldots \ldots \ldots \ldots 27$

Table 11. Properties of MTR and Commercially Available Protective Fabrics ....... 29

Table 12. Mechanical Properties of Coated Woven Fabrics .................. 31

Table 13. Mechanical Properties of Coated Fabrics Using Non-Woven Support

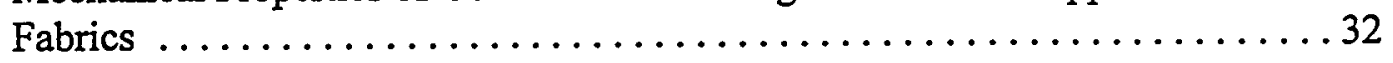

Table 14. Adsorption Capacities of Sorbent Layers and Pure Sorbents ............ 34

Table 15. Mechanical Properties of PVDF and Polyurethane Sorbent-Containing Fabrics

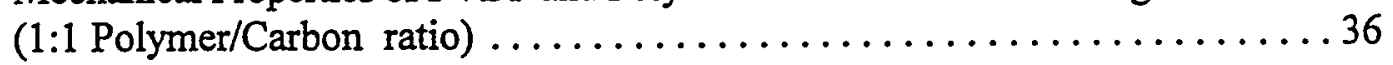

Table 16. Relationship Between Carbon Loading in Sorbent Matrix and Mechanical Properties .................................... 37

Table 17. Effect of Permselective Layer Type and Thickness on Dichloromethane Permeation .................................. 42

Table 18. Effect of Water Vapor on Dichloromethane Permeation .............. 43

Table 19. Airvol Polyvinyl Alcohol (PVA) Grades ................... 45

Table 20. Characteristics of Polyvinyl Alcohol (PVA) Layers Crosslinked by Various Methods ....................................... 48

Table 21. Properties of Membranes Made with Different Crosslinking Agents Compared with Safety and Ease of Use of Agent $\ldots \ldots \ldots \ldots \ldots \ldots \ldots \ldots \ldots . \ldots \ldots$ 


\section{LIST OF TABLES - CONTINUED}

Table 22. Specification and Properties of Fabrics Laminated by Direct Bonding ....... 51

Table 23. Summary of Protective Fabric Materials and Production Process .......... 52

Table 24. Summary of Results of Laboratory Protective Fabric Tests $\ldots \ldots \ldots \ldots . \ldots 53$

Table 25. Effect of Casting Solution Concentrations and Viscosities on Nitrogen Permeation Flux of Sorbent Layer and MVTR of Complete Fabric ........ 55

Table 26. Conditions for Production-Scale Casting Runs ................. 56

Table 27. Summary of Heat Stress Modeling Results for MTR's Protective Clothing and

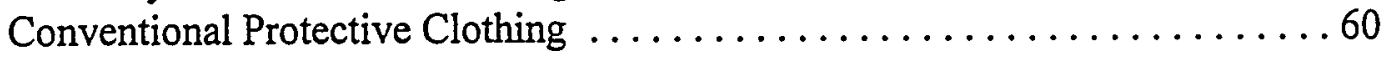

Table 28. Material Quantities Needed for MTR Fabrics ..................6 62

Table 29. Capital Costs for Commercial-Scale Fabric Manufacturing Equipment . . . . . 63

Table 30. Total Fabric Manufacturing Cost $\ldots \ldots \ldots \ldots \ldots \ldots \ldots \ldots \ldots \ldots \ldots \ldots \ldots \ldots \ldots \ldots$

Table 31. Cost/Benefit Calculations for the MTR-1 and MTR-2 Suits Compared to Saranex-Coated Tyvek Suits, Assuming Suits are Exchanged Daily and

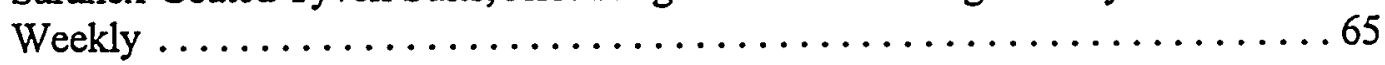

Table 32. Total Fabric Manufacturing Cost $\ldots \ldots \ldots \ldots \ldots \ldots \ldots \ldots \ldots \ldots \ldots \ldots \ldots \ldots \ldots \ldots \ldots$

Table 33. Cost-Benefit Calculations for the MTR-1, MTR-2, and MTR-Imp Suits Compared to Saranex-Coated Tyvek Suits .....................67 67 


\section{EXECUTIVE SUMMARY}

Over the next three decades, the Department of Energy (DOE) faces an enormous decontamination and decommissioning task as facilities associated with research, development, and production of atomic weapons are closed. This task is complex and expensive because many sites are contaminated with a variety of hazardous compounds ranging from asbestos, mercury and other heavy metals, to toxic organic compounds, such as polychlorinated biphenyls (PCBs) and chlorinated solvents, and radioactive metals and salts. Because of the hazards of exposure to these materials, workers must frequently wear completely encapsulating protective garments. These garments are impermeable to particulates, aerosols, and organic vapors and provide good protection from toxic contaminants. However, the garments are heavy, time consuming to don and remove, and most importantly, are impermeable to water vapor. Since the garments are water vapor impermeable, it is very difficult for body heat to escape. As a result, workers easily become heat stressed and must rest frequently.

The goal of this project is to develop chemical protective clothing for use by DOE decontamination and decommissioning workers that will increase worker productivity-because it is cooler and more comfortable than conventional protective clothing-while maintaining protection against chemical liquids and vapors. This report describes the results from Phase I of the two-phase project to complete development of the fabric and to demonstrate its utility in field trials at DOE sites. In the first phase, the fabric properties were improved by modifying both the materials and the preparation procedure used to form the membrane. Production of the fabric was then scaled up to use commercial-scale production machinery. A small number of prototype suits were made, and a preliminary suit evaluation was conducted. In Phase II, current plans are to produce 300-400 suits will be produced for a complete laboratory and field demonstration program.

Heat stress, which refers to a number of illnesses resulting from overheating, is one of the primary drawbacks of wearing protective clothing. As the body's core temperature rises above $98.6^{\circ} \mathrm{F}$, motor and mental skills become sluggish. Cramps, heat fatigue and exhaustion, dizziness, collapse, or even stroke may follow. These problems are known under a variety of names including heat rash, heat fatigue, heat cramp, heat exhaustion, heat collapse, and heat stroke. The potential for heat stress depends on two factors: the rate at which the body generates heat and the rate at which the body can dissipate heat to the environment. The body naturally generates heat through metabolism; as metabolism increases (for example, through strenuous activity), the amount of heat generated also increases.

To maintain a constant temperature, the body must get rid of this metabolic heat by dissipating it to the environment. If the body cannot dissipate enough heat, the body temperature begins to rise, resulting in heat stress. Heat dissipation occurs by a number of mechanisms including conduction, convection, radiation, and evaporation. The environmental conditions (temperature, humidity, air movement) determine how much heat can be dissipated by each mechanism. For example, on cold, windy days, heat is easily lost through convection; on high humidity days, very little heat can be lost through evaporation. The human body has two mechanisms to actively control heat dissipation. The first is regulation of blood flow near the skin: as body temperature increases, 
the blood flow is increased to the skin from which heat is dissipated to the air by conduction. The closer the surrounding air temperature is to the body temperature, the less effective is this mechanism at dissipating heat and cooling the body. As the temperature rises, more and more heat is dissipated by the second mechanism-evaporation. At temperatures above $95^{\circ} \mathrm{F}$, almost all heat is lost through evaporation. The body exploits the evaporation mechanism through sweating-as sweat evaporates it carries heat with it, cooling the body. If the surrounding air is saturated with water, sweat will not evaporate, and this mechanism is not effective in cooling the body.

Protective clothing has become lighter weight and more flexible during the past 10 years, with the introduction of multilayer polymer fabrics such as Saranex-coated Tyvek. The light weight reduces the heat insulative characteristics of the fabrics, and the flexibility reduces the effort required to move around in them. However, these fabrics are still impermeable to water vapor, so workers are still exposed to heat stress. A second advance is the development of protective clothing that allows permeation of water vapor, but still protects against chemical hazards. Some waterpermeable fabrics provide limited protection against liquid chemicals, but not against chemical vapors. The goal of this project is to develop water-permeable fabrics that also provide chemical protection against both liquid and vapor hazards.

Prior to this project, Membrane Technology and Research, Inc. (MTR) had developed improved protective clothing fabric that provides protection equivalent to that in current suits, but is water-vapor-permeable to minimize heat stress, and lighter weight for improved wearer comfort. The innovative feature of this improved fabric is an ultrathin, permselective membrane that is extremely permeable to water but impermeable to toxic organic compounds. The membrane layer protects the body from all particulate and liquid hazards and gives extended protection against organic vapors. To add further protection, the fabric has a sorptive layer, consisting of a porous membrane containing dispersed carbon adsorbent. This layer increases the protective capacity against organic liquids and vapors and acts as a backup barrier in case the outer membrane is breached by abrasion or wear. The membrane layers are coated onto a conventional nylon fabric that provides mechanical strength. Improvements needed for this fabric included increased durability and flexibility, and reduced weight and thickness. Also, this fabric had been produced only on a small scale, and needed to be scaled up to quantities large enough to make prototype suits. The criteria defining a successful fabric are summarized in Table 1. 
Table 1. Protective Fabric Criteria

\section{Water vapor transmission rate}

Heat stress measurements indicate that a worker wearing the MTR suit will be measurably cooler than if wearing a conventional Saranex-coated Tyvek suit.

\section{Chemical permeation rate}

Dichloromethane breakthrough time $(\sim 5 \mathrm{~min})$ and permeation rate should be comparable to Saranex-coated Tyvek fabric $\left(\sim 100 \mu \mathrm{g} / \mathrm{cm}^{2} \cdot \mathrm{min}\right)$.

\section{Fabric durability}

Suits have flexibility and durability comparable to current chemical protective clothing.

\section{Fabric manufacturability}

Enough full-scale rolls of fabric ( $1 \mathrm{~m}$ wide $\times 100 \mathrm{~m}$ long) have been produced to make 10 to 20 prototype suits

\section{Suit manufacturability}

A cooperating manufacturing company has been identified and 10-15 suits for laboratory tests have been produced.

\section{Cost effectiveness of suit}

An economic analysis shows that the savings due to higher worker productivity are greater than the price difference between MTR and lower-cost conventional suits.

The goal of Phase I of this project was to produce optimized fabric meeting the criteria shown in Table 1 in commercial-scale rolls, and to make and test prototype suits. The specific objectives of Phase I were to:

- Produce high-quality protective fabric in rolls $1 \mathrm{~m}(40 \mathrm{in})$ wide and 100-200 m (100-200 yd) long.

- Incorporate this material into prototype suits.

- Evaluate the suits in the laboratory.

- Conclude an agreement with a collaborating suit manufacturer to produce demonstration suits for Phase II of the project.

To accomplish these objectives, the Phase I project had three major components: fabric optimization, commercial-scale fabric production, and prototype suit production and evaluation. An outline of each component and a summary of the results of the work are given below.

a) Fabric Optimization: Fabric optimization involved optimization of the individual layers included in the final protective fabric, and optimization of the way these layers are combined. The fabric components studied during the fabric optimization process were the support fabric, the sorbent 
layer (including the sorbent used, the polymer used, and the ratio of the two), and the permselective layer (including the polymer and post-treatment methods). We also studied the geometry used to combine the individual layers into the final protective fabric. The resulting fabric combined four attributes: resistance to chemical permeation, high water vapor transmission rates, durability, flexibility and light weight.

During the project, we developed two fabrics-MTR-1 and MTR-2 - that combine the four attributes. Figure 1 shows a diagram of MTR-2, which is a laminate of two identical, composite fabrics that we refer to as permselective fabric. The permselective fabric is manufactured by casting a sorptive layer of zeolite-loaded poly(vinylidene fluoride) on a woven support fabric. A thin permselective polymer layer of polyvinyl alcohol is solution-coated onto the sorbent layer. The two permselective fabrics are laminated by joining the permselective layers, leaving the woven support fabric on both outer surfaces of the protective fabric (or laminated fabric). MTR-1 consists of one permselective fabric layer laminated to a nonwoven fabric, which forms the inside layer of the resulting fabric. Thus, MTR-1 is more comfortable but less protective than MTR-2. Both fabrics combine moderate chemical permeation resistance, moderate water transmission, and good physical properties and durability.

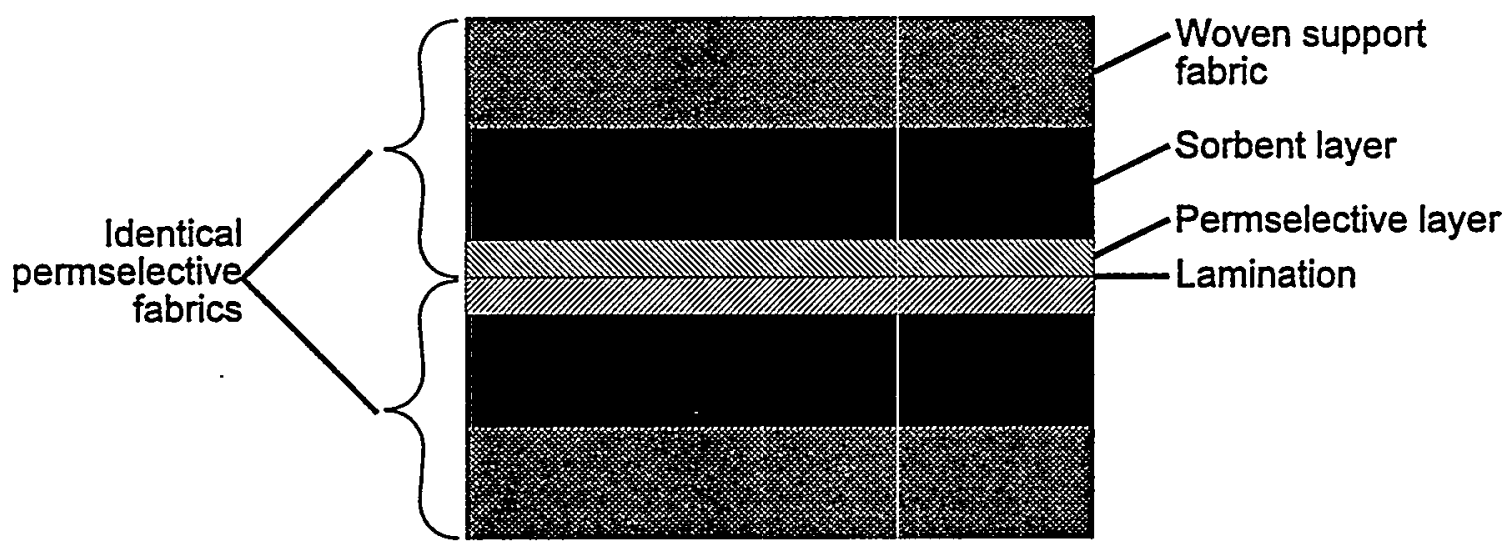

Figure 1. Structure of MTR-2 protective clothing fabric.

b) Commercial-Scale Fabric Production: Commercial-scale fabric production involved scaling up from the 12-inch-wide machines used during fabric optimization to 40-inch-wide machines. Outside suppliers of techniques and methods not available within MTR were identified as necessary. Rolls of 40-inch-wide $(1 \mathrm{~m})$ fabric at least $100 \mathrm{~m}$ long were required for use in prototype suit fabrication; a reliable fabrication method was developed for use in future commercial production.

Problems encountered and solved during scale-up resulted mainly from difficulties in handling the wider fabric, for example, wrinkling and curling of the edges. One roll of MTR-2 was prepared plus one roll using the nonwoven material for the inner layer (MTR-1). Evaluations of the fabric performed by outside laboratories included: chemical permeation, moisture vapor transmission rate (MVTR), and physical properties. The results showed that the water vapor 
transmission goal was met, and that the chemical permeation resistance was adequate, but not as high as hoped. Table 2 shows a comparison of the new fabrics with currently available protective clothing.

Table 2. Properties of MTR and Commercially Available Protective Fabrics

\begin{tabular}{|l|c|c|c|c|c||}
\hline \multicolumn{1}{|c|}{ Property } & MTR-1 & MTR-2 & Tyvek & $\begin{array}{c}\text { Saranex- } \\
\text { Coated } \\
\text { Tyvek }\end{array}$ & Barricade \\
\hline $\begin{array}{l}\text { Chemical Permeation } \\
\left(\text { dichloromethane) }\left(\mu \mathrm{g} / \mathrm{cm}^{2} \cdot \mathrm{min}\right)\right.\end{array}$ & 440 & 165 & high & 120 & $<0.1$ \\
\hline $\begin{array}{l}\text { Water Vapor Transmission } \\
\left(\text { MVTR) }\left(\mathrm{g} / \mathrm{m}^{2} \cdot \mathrm{day}\right)\right.\end{array}$ & $800-1,200$ & $800-1,300$ & $1,000-2,000$ & 0 & 0 \\
\hline Thickness (mils) & 10 & 8 & 8 & 10 & 21 \\
\hline Weight (oz/sq yd) & 6 & 6 & 1 & 4 & 5 \\
\hline
\end{tabular}

c) Prototype Suit Production and Evaluation: Several manufacturers of protective clothing were contacted; Kappler Safety Group, Gantesville, AL was eventually selected to make prototype suits. Twelve prototype suits were made: 7 from MTR-2 fabric, and 5 from MTR-1 fabric. The suits were evaluated for chemical protection, physical characteristics, and effect on worker productivity. Finally an economic evaluation was performed to compare the value of increased worker productivity versus the cost of the suit. An estimate of the commercial potential of the fabric was made from the economic analysis and market estimates.

Heat stress modeling indicated the MTR fabrics increase worker productivity over conventional Saranex-coated Tyvek suits, but the increase was not as large as expected based on the water vapor transmission results (Table 2). Using production cost estimates, we quantified the potential benefits of protective clothing made from our fabric. The estimated price for suits made from MTR's fabrics are $\$ 60$ and $\$ 66$ for fabrics MTR-1 and MTR-2, respectively; the cost of a conventional occlusive suit is $\$ 31$. Based on these costs and a $10 \%$ improvement in worker productivity, the cost benefit of using water-vapor-permeable suits compared to occlusive suits can be calculated. The analysis shows that the water-vapor-permeable suit is cost effective if worn for two days or more.

A moderate cost reduction and a slight improvement in water vapor transmission rate would make the MTR fabric competitive if exchanged daily. The cost reduction can be achieved by using a less expensive material for the support fabric and reducing the costs for capital equipment; the water transmission rate can be increased by optimizing the lamination process. If these improvements were made, the drop in fabric price would result in a suit price of $\$ 56$. All of these improvements could be achieved by teaming with a company that has expertise with conventional fabric production. 
We conclude that the fabrics produced during this project are a significant advancement in state-of-the-art protective fabrics. No available fabrics combine protection against vapor as well as liquid chemical hazards while reducing the potential for heat stress by allowing water vapor to permeate the fabric. MTR's fabrics achieved the water vapor transmission rate goals (greater than $800 \mathrm{~g} / \mathrm{m}^{2} \cdot$ day) and provided chemical protection similar to currently used non-water-vaporpermeable chemical protective suits. These results were achieved in a practical fabric that is strong, durable, flexible, lightweight, and easy to manufacture into a suit. We also believe that the fabric cost can be reduced further, to make MTR's fabric an attractive alternative for users of chemical protective clothing.

\section{INTRODUCTION}

The goal of this project is to develop chemical protective clothing for use by DOE decontamination and decommissioning workers that will increase worker productivity-because it is cooler and more comfortable than conventional protective clothing-while maintaining protection against chemical liquids and vapors.

This report describes the results from Phase I of a two-phase project to complete development of the fabric and to demonstrate its utility in field trials at DOE sites. In the first phase, the fabric properties were improved by modifying both the materials and the preparation procedure used to form the membrane. Production of the fabric was then scaled up to use commercial-scale production machinery. A small number of prototype suits were made, and a preliminary suit evaluation was conducted. In Phase II, current plans are to produce 300-400 suits for a complete laboratory and field demonstration program.

\subsection{Background to DOE Problem}

Over the next three decades, the Department of Energy faces an enormous decontamination and decommissioning task as facilities associated with research, development, and production of atomic weapons are closed. This task is complex and expensive because many sites are contaminated with a variety of hazardous compounds ranging from asbestos, mercury and other heavy metals, to toxic organic compounds, such as PCB and chlorinated solvents, and radioactive metals and salts. Because of the hazards of exposure to these materials, workers must frequently wear completely encapsulating protective garments. These garments are impermeable to particulates, aerosols, and organic vapors and provide good protection from toxic contaminants. However, the garments are heavy, time consuming to clon and remove, and most importantly, are impermeable to water vapor. Since the garments are water vapor impermeable, it is very difficult for body heat to escape. As a result, workers easily become heat stressed and must rest frequently.

\subsection{Personal Protective Equipment}

When performing decontamination and decommissioning tasks at hazardous or radioactive facilities, the equipment and procedures used to protect the workers also lower worker efficiency and productivity. Depending on the hazards present, workers may be required to wear respiratory 
protection; particle, liquid, or vapor resistant clothing; layered boots and gloves; and even selfcontained breathing apparatus (SCBA). These items of personal protective equipment (PPE) reduce worker efficiency and productivity because they

- restrict mobility, vision, and communication;

- increase fatigue due to the weight and restrictiveness of the equipment;

- reduce working time because of the non-working time required for donning and doffing PPE, decontamination, equipment changes (for example, air tanks), and special training and inspection; and

- increase heat stress due to impermeability to water vapor (sweating cannot effectively cool the body if water vapor cannot escape from the suit), requiring more frequent breaks and reducing efficiency while working.

The degree to which these factors affect worker productivity depends on the seriousness of the hazard present at the site.

The EPA has categorized four levels of chemical protective clothing; the level required for a given situation depends on the amount and toxicity of the chemicals present, the duration of exposure, and the physical environment. In extreme (or unknown) conditions, the highest level of skin and respiratory protection (Level A) is required. Level A protection requires a gas-tight, fully encapsulating suit with gas-tight closures to boots and gloves. Breathing air must be supplied by SCBA or an airline respirator. To protect against many chemical agents found at hazardous sites, not only must the suit be gas-tight, but the fabric must not allow significant permeation of the chemical through the fabric itself. To achieve this high degree of protection, the worker must contend with heavy/bulky equipment, thick/stiff fabrics, and hot/impermeable suits.

Less hazardous situations require less protective equipment. Level B protection is used when the skin-absorption hazard of the chemical is not as severe as at Level A. Level B protection includes the same respiratory protection as Level A (SCBA), but non-gas-tight suits are acceptable. Level $C$ requires the same protective clothing as Level $B$, but a respirator is used instead of SCBA. The lowest level of protection defined by the EPA, Level D, consists of essentially standard work clothing. Depending on the site, all levels may require use of a hard hat, protective gloves, hearing protection, and foot protection.

These EPA standards are not the only guidelines available to users of PPE.(1) The National Fire Protection Association has a set of very specific standards for protective guidelines; OSHA also has standards that, although not very specific, are enforceable by law. Manufacturers of protective equipment also provide advice on the suitability of their equipment for use under various conditions. In the end, the user must determine what PPE is appropriate for the specific conditions of the particular site being worked on; these decisions require individuals with expertise in health and safety issues, understanding of the types of PPE available, and knowledge of the hazards to be encountered at the site. 


\subsection{Current Protective Clothing}

As with PPE in general, different levels of personal protective clothing (PPC) are worn under different hazardous conditions. The types of PPC that correspond approximately to the EPA's levels of protection are shown in Table 3. ${ }^{1}$ Typically the protective clothing used at DOE sites is of the Level B or C variety. Although these suits are light and relatively inexpensive, they are impermeable to water and therefore hot, increasing the potential for heat stress and reduced productivity.

Another way to look at the current state of chemical protective clothing is to compare the protection characteristics and the comfort characteristics of commercially available clothing. Figure 2 shows a qualitative comparison of these characteristics for several commercial suits. Clothing worn against particulate hazards ranges from permeable to impermeable; typically clothing worn to protect against volatile organic compounds (VOCs) is completely impermeable to water vapor.

1 The EPA does not describe specific standards for clothing to meet their guidelines for protective levels, so these types of clothing are only MTR's interpretation of the PPC that would be appropriate for a particular level of protection. 
Table 3. EPA Levels of Chemical Protective Clothing

\begin{tabular}{|c|c|c|c|c|c|}
\hline $\begin{array}{l}\text { EPA : } \\
\text { Protection } \\
\text { Level }\end{array}$ & Hazards & Fabric , & Construction & Commercial Examples & Disadvantages \\
\hline Level A & $\begin{array}{l}\text { Extreme } \\
\text { Respiratory } \\
\text { Skin (vapor } \\
\text { and liquid) }\end{array}$ & $\begin{array}{l}\text { Extremely resistant to } \\
\text { chemical permeation } \\
\text { and degradation }\end{array}$ & $\begin{array}{l}\text { One-piece, } \\
\text { gas-tight, } \\
\text { sealed seams }\end{array}$ & $\begin{array}{l}\text { Challenge } 6400(R, M, v E) \\
\text { Responder }(D, M, E) \\
\text { Chemrel Max }(D, M, E) \\
\text { Trellchem Extra }(R, S, v E)\end{array}$ & $\begin{array}{l}\text { Expensive, impermeable } \\
\text { to water vapor (very } \\
\text { hot), thick and stiff, } \\
\text { cumbersome }\end{array}$ \\
\hline Level B & $\begin{array}{l}\text { Moderate } \\
\text { Respiratory } \\
\text { Skin (vapor } \\
\text { and liquid) }\end{array}$ & $\begin{array}{l}\text { Moderately resistant to } \\
\text { chemical permeation } \\
\text { and degradation }\end{array}$ & $\begin{array}{l}\text { Sealed } \\
\text { seams }\end{array}$ & $\begin{array}{l}\text { Tyvek/Saranex-coated Tyvek Haz-Mat Response } \\
\text { Suit (D, M, I) } \\
\text { Tychem } 9400 \text { Splash Suit (D, M, E) } \\
\text { Kappler CPF IV Splash Suit (D, M, E) }\end{array}$ & $\begin{array}{l}\text { Moderate cost, } \\
\text { impermeable to water } \\
\text { vapor (very hot), } \\
\text { cumbersome, only } \\
\text { moderate chemical } \\
\text { protection }\end{array}$ \\
\hline Level C & $\begin{array}{l}\text { Low } \\
\text { Respiratory } \\
\text { Skin } \\
\text { (liquid) }\end{array}$ & $\begin{array}{l}\text { Resistant to chemical } \\
\text { degradation and } \\
\text { penetration by liquids; } \\
\text { no permeation } \\
\text { resistance }\end{array}$ & $\begin{array}{l}\text { Sewn } \\
\text { seams }\end{array}$ & $\begin{array}{l}\text { Coveralls made from variety of fabrics including Tyvek, } \\
\text { Tyvek/Saranex-coated Tyvek, Tychem, Kappler CPF, } \\
\text { Chemrel, PVC, Neoprene, Comfort-Gard } \\
\text { (D or R, S or M, I or C) }\end{array}$ & $\begin{array}{l}\text { Cheap, low water vapor } \\
\text { permeation (hot), light } \\
\text { and flexible, little } \\
\text { chemical protection }\end{array}$ \\
\hline Level D & Very low & No chemical protection & $\begin{array}{l}\text { Sewn } \\
\text { seams }\end{array}$ & $\begin{array}{l}\text { Clothing made from variety of fabrics including Tyvek, } \\
\text { Cotton, Polyester, etc. } \\
\text { (D or R, S or M, I or C) }\end{array}$ & $\begin{array}{l}\text { Cheap, breathable } \\
\text { (cool), light and } \\
\text { flexible, no chemical } \\
\text { protection }\end{array}$ \\
\hline $\begin{array}{l}\text { D, R } \\
\text { S, M } \\
\text { vE, E, I, C }\end{array}$ & disposabl & eusable & site fabric & moderate price $(>\$ 20-100)$, inexpensive $<\$ 20)$ & \\
\hline
\end{tabular}




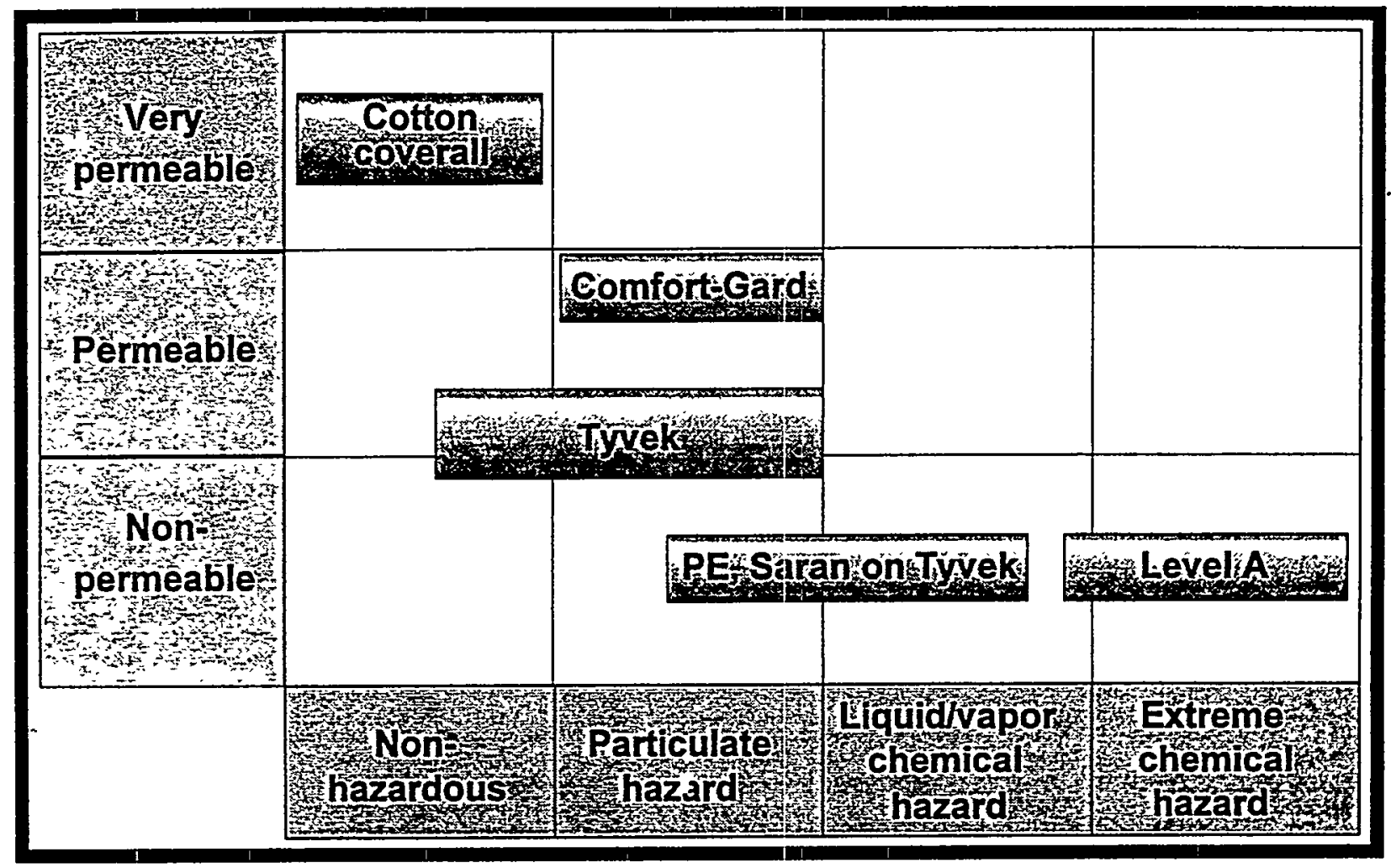

Figure 2. Water vapor permeability and protective characteristics of commercially available clothing [ $\mathrm{PE}=$-polyethylene].

\subsection{Heat Stress}

Heat stress, which refers to a number of illnesses resulting from overheating, is one of the primary drawbacks of wearing protective clothing.(2-5) As the body's core temperature rises above $98.6^{\circ} \mathrm{F}$, motor and mental skills become sluggish. Cramps, heat fatigue and exhaustion, dizziness, collapse, or even stroke may follow. These problems are known under a variety of names including heat rash, heat fatigue, heat cramp, heat exhaustion, heat collapse, and heat stroke.

The potential for heat stress depends on two factors: the rate at which the body generates heat and the rate at which the body can dissipate heat to the environment. The body naturally generates heat through metabolism; as metabolism increases (for example, through strenuous activity), the amount of heat generated also increases.

To maintain a constant temperature, the body must get rid of this metabolic heat by dissipating it to the environment. If the body cannot dissipate enough heat, the body temperature begins to rise, resulting in heat stress. Heat dissipation occurs by a number of mechanisms including conduction, convection, radiation, and evaporation. The environmental conditions (temperature, humidity, air movement) determine how much heat can be dissipated by each mechanism. For example, on cold, windy days, heat is easily lost through convection; on high humidity days, very little heat can be lost through evaporation. The human body has two mechanisms to actively control 
heat dissipation. The first is regulation of blood flow near the skin; as body temperature increases, the blood flow is increased to the skin from which heat is dissipated to the air by conduction. The closer the surrounding air temperature is to the body temperature, the less effective is this mechanism at dissipating heat and cooling the body. As the temperature rises, more and more heat is dissipated by the second mechanism - evaporation. At temperatures above $95^{\circ} \mathrm{F}$, almost all heat is lost through evaporation. The body exploits the evaporation mechanism through sweating; as sweat evaporates, it carries heat with it and cools the body. If the surrounding air is saturated with water, sweat will not evaporate, and this mechanism is not effective in cooling the body.

From the proceeding discussion, it is apparent that the potential for heat stress rises when:

- The rate of metabolic heat generation is high (from strenuous activity).

- The rate of convective heat dissipation is low (due to either high ambient temperature or to clothing that insulates the body or prevents air flow to the body).

- The rate of evaporative heat transfer is low (because ambient humidity is high or because impermeable clothing prevents the escape of water vapor, resulting in saturated air immediately adjacent to the skin).

The American Conference of Government Industrial Hygienists (ACGIH) has issued "Permissible Heat Exposure Threshold Limit Values."(6) These limits, summarized in Figure 3, depend on the wet bulb globe temperature (WBGT: a combination of ambient temperature, humidity, and radiation), the work load, and the type of clothing being worn. For example, if the WBGT at the worksite is $85^{\circ} \mathrm{F}\left(29^{\circ} \mathrm{C}\right)$ and the level of work is moderate, the worker can work for only $50 \%$ of each hour. The remaining portion of each hour must be used for resting in a cooler environment. 


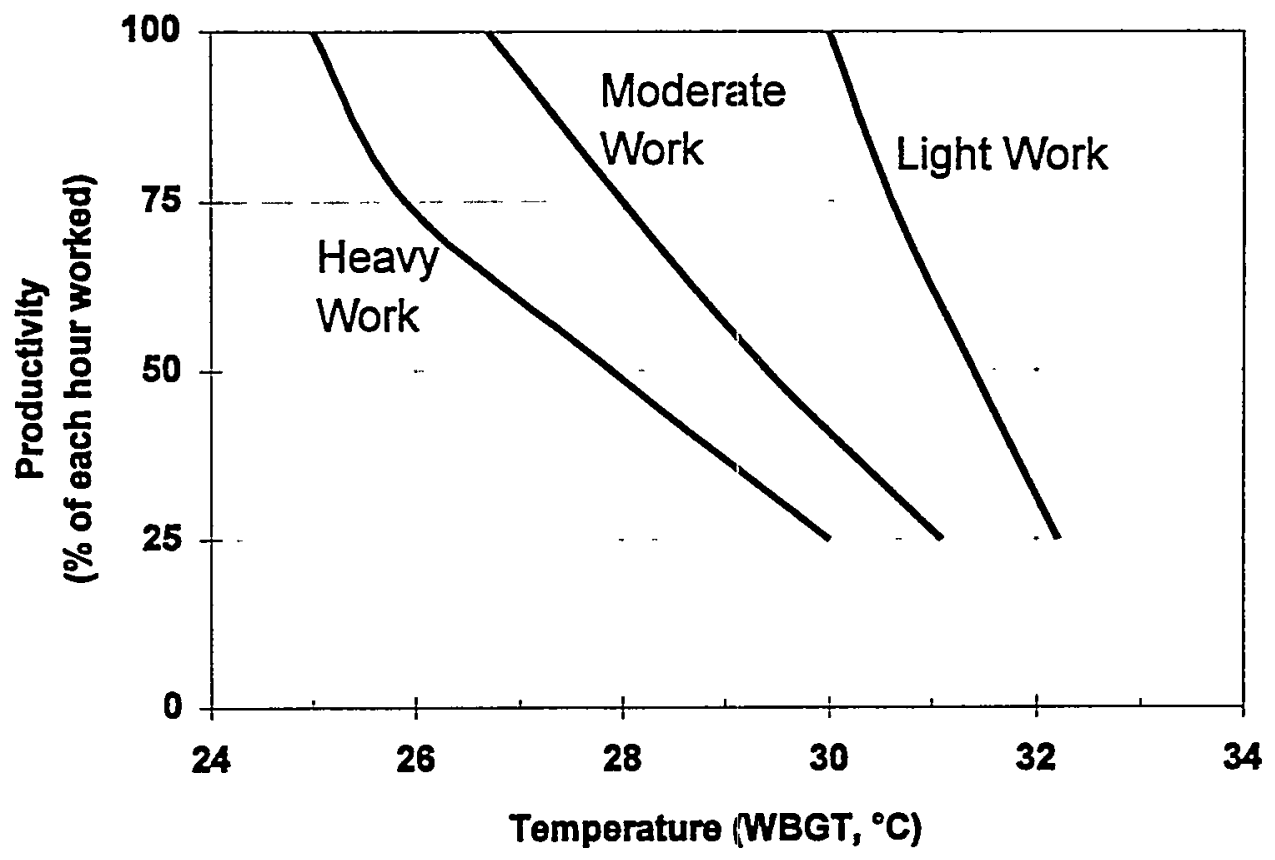

Figure 3. Heat stress exposure limits recommended by the American Conference of Government Industrial Hygienists (ACGIH). (Worker is assumed to be wearing summer-weight work clothes.)

The type of clothing plays an important role in determining susceptibility to heat stress, and the length of time a worker can work before the ACGIH heat stress limits are reached. Figure 4 shows the ACGIH limits for a worker performing moderate work with different types of clothing. Using the example of a slightly cooler worksite than above $\left(80^{\circ} \mathrm{F}, 27^{\circ} \mathrm{C}\right)$, the worker can spend $100 \%$ of each hour working in summer-weight clothing, but only $25 \%$ in a winter work uniform. Wearing a suit that is impermeable to water vapor limits working time even further. 


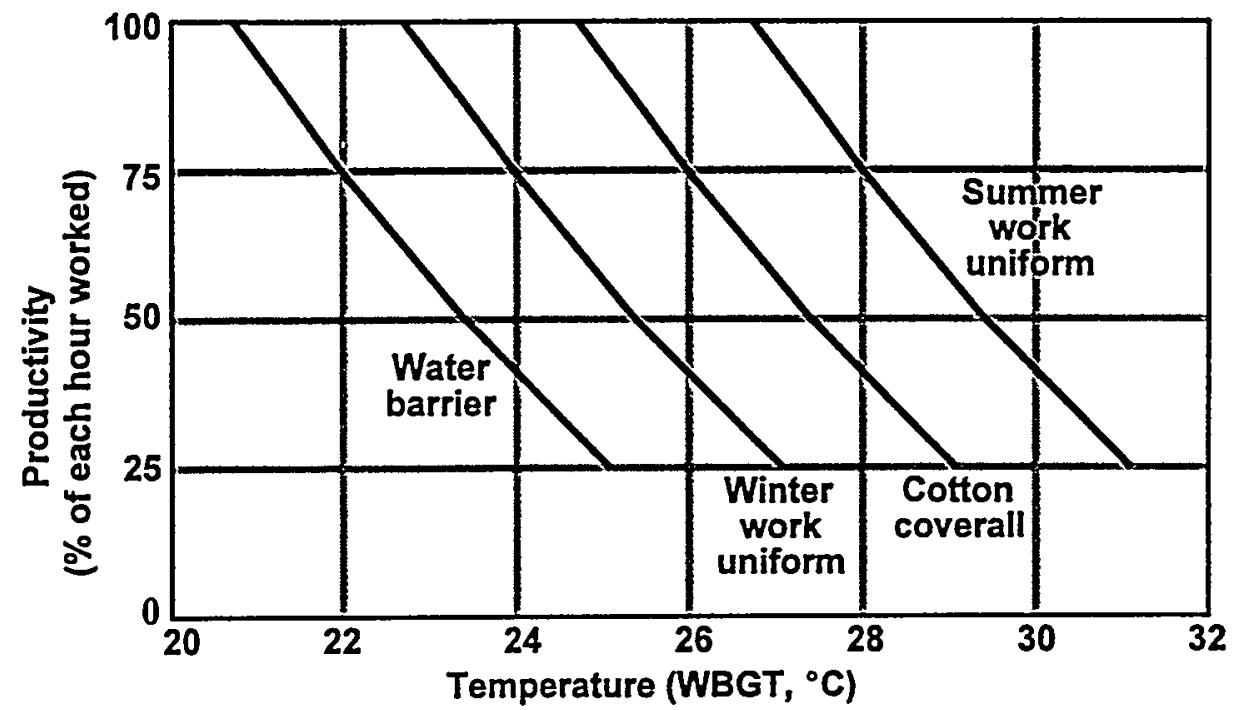

Figure 4. Effect of clothing type on heat stress exposure limits (under moderate work load).

The ACGIH heat exposure limits demonstrate the restrictions that heat stress and protective clothing place on worker productivity, and indicate the need for ways to keep workers cool while still protecting them from chemical hazards. To keep workers cool, one of two approaches (other than frequent rests and working during cool parts of the day) is used: cooling vests or lightweight, water-vapor-permeable clothing.

The simplest form of cooling vest contains ice packs; the more sophisticated form contains tubes through which cool water can be pumped. Cooling vests are commercially available; however, they have several drawbacks. The vests are heavy and cumbersome, they have a limited life before they need to be regenerated, and health problems have been reported due to uneven cooling supplied by some models.

Protective clothing has become lighter weight and more flexible during the past 10 years, with the introduction of multilayer, polymer fabrics such as Saranex-coated Tyvek. The light weight reduces the heat insulative characteristics of the fabrics, and the flexibility reduces the effort required to move around in them. However, these fabrics are still impermeable to water vapor, so workers are still exposed to heat stress. A second advance is the development of protective clothing that allows permeation of water vapor, but still protects against chemical hazards. Some watervapor-permeable fabrics provide limited protection against liquid chemicals, but not against chemical vapors. The goal of this project is to develop water-vapor-permeable fabrics that also provide chemical protection against both liquid and vapor hazards.

\subsection{Background to MTR's Protective Clothing Technology}

Prior to this project, Membrane Technology and Research, Inc. (MTR) had developed improved protective clothing fabric that provides protection equivalent to that in current suits, but 
is water-vapor-permeable to minimize heat stress, and lighter weight for improved wearer comfort. The innovative feature of this improved fabric is an ultrathin, permselective membrane layer that is extremely permeable to water but impermeable to toxic organic compounds (Figure 5). The membrane layer protects the body from all particulate and liquid hazards and gives extended protection against organic vapors. To add further protection, the fabric has a sorptive layer, consisting of a porous membrane containing dispersed carbon adsorbent. This layer increases the protective capacity against organic liquids and vapors and acts as a backup barrier in case the outer membrane is breached by abrasion or wear. The membrane layers are coated onto a conventional nylon fabric that provides mechanical strength. The moisture vapor transmission rate (MVTR) through this fabric is $600-950 \mathrm{~g} / \mathrm{m}^{2}$ day, compared to protective impermeable butyl rubber suits with a transmission rate of $0-10 \mathrm{~g} / \mathrm{m}^{2} \cdot$ day, and non-protective porous Tyvek suits with a transmission rate of $1,000-2,000 \mathrm{~g} / \mathrm{m}^{2} \cdot$ day.

Rolls of the fabric $30 \mathrm{~cm}$ (12 in) wide and $100 \mathrm{~m}$ (100 yd) long are produced routinely. A few rolls had been made on commercial-scale machinery to produce fabric $1 \mathrm{~m}$ ( $40 \mathrm{in}$ ) wide. The fabric had been extensively tested in the laboratory and had been shown to give protection against organic compounds. However, the fabric needed improvement for it to be commercially acceptable, particularly in the areas of chemical protection, flexibility, and durability. These issues were the focus of this project.

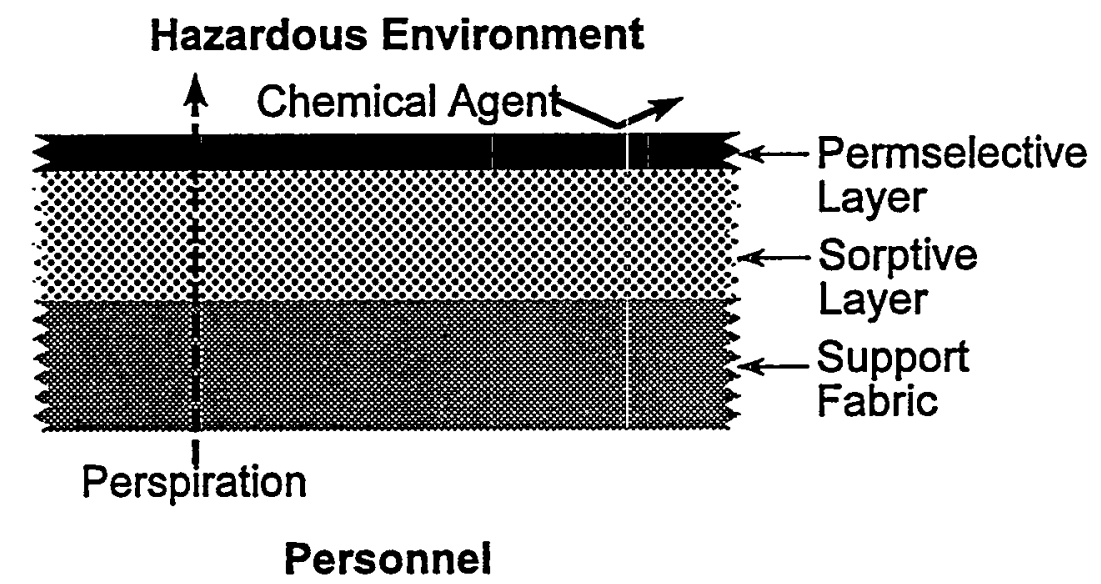

Figure 5. MTR's protective clothing concept.

\section{RESEARCH PLAN}

\subsection{Overall Objective}

The goal of the Phase I project was to produce optimized fabric in commercial-scale rolls and to make and test prototype suits. The specific objectives of Phase I were to: 
- Produce high-quality protective fabric in rolls $1 \mathrm{~m}(40 \mathrm{in})$ wide and 100-200 m (100-200 yd) long.

- Incorporate this material into prototype suits.

- Evaluate the suits in the laboratory.

- Conclude an agreement with a collaborating suit manufacturer to produce demonstration suits for Phase II of the project.

A number of specific issues (technical, production, regulatory, and economic) had to be resolved for this project to have a successful outcome. Some of these issues are listed in Table 4.

Table 4. Issues to be Resolved During Technology Development

\begin{tabular}{|c|c|}
\hline Issue & Phase \\
\hline $\begin{array}{l}\text { Technical Issues } \\
\text { 1. Current fabric flexibility and durability is marginal. } \\
\text { 2. A final determination of the proper balance between } \\
\text { comfort and protection has not been made. } \\
\text { 3. Lifetime of suit not established. }\end{array}$ & $\begin{array}{l}\text { I } \\
\text { I }\end{array}$ \\
\hline $\begin{array}{l}\text { Production Issues } \\
\text { 1. Only limited experience has been generated with industrial- } \\
\text { scale fabric production equipment. } \\
\text { 2. Suit production issues have not been addressed to date. } \\
\text { MTR has limited experience in this area. } \\
\text { 3. Suit design not established }\end{array}$ & $\begin{array}{l}\text { I } \\
\text { I }\end{array}$ \\
\hline $\begin{array}{l}\text { Regulatory Issues } \\
\text { 1. Suits not yet tested under field conditions to convince } \\
\text { potential users of safety and efficiency. }\end{array}$ & II \\
\hline $\begin{array}{l}\text { Economic Issues } \\
\text { 1. True cost of fabric and suits made from this fabric are not } \\
\text { known. } \\
\text { 2. Production and market strategy not defined }\end{array}$ & I \\
\hline
\end{tabular}

\subsection{Performance Goals}

Our proposal included specific criteria for the Phase I fabric scale-up and production and the preliminary suit studies to be considered successful. However, comparison with current commercially available suits has lead us to believe that these criteria were unnecessarily strict. Certainly, a suit meeting our criteria would be very successful in that it would be far better than any suit now available; however, suits not meeting these strict requirements may still be an improvement over currently available suits and should not be ruled out. We believe a successful outcome of this 
project is a suit with chemical protective properties and durability similar to current suits, but with water vapor transmission properties that will allow longer working hours due to reduced heat stress. Table 5 compares our original success criteria with those we now believe are more realistic.

Table 5. Success Criteria

\begin{tabular}{|c|c|}
\hline Original Criteria & Realistic Criteria \\
\hline \multicolumn{2}{|l|}{ 1. Water vapor transmission } \\
\hline $\begin{array}{l}\text { The test fabric to achieve a moisture vapor } \\
\text { transmission rate (MVTR) of } 800-1,000 \\
\mathrm{~g} / \mathrm{m}^{2} \text {.day. Suits are significantly more } \\
\text { comfortable than Saranex-coated Tyvek or } \\
\text { butyl rubber suits. }\end{array}$ & $\begin{array}{l}\text { Heat stress measurements indicate that a } \\
\text { worker wearing the MTR suit will be able to } \\
\text { work measurably longer without a break than if } \\
\text { wearing a conventional Saranex-coated Tyvek } \\
\text { suit. }\end{array}$ \\
\hline \multicolumn{2}{|l|}{ 2. Chemical permeation } \\
\hline $\begin{array}{l}\text { Dichloromethane breakthrough time of greater } \\
\text { than } 300 \text { minutes, with a dichloromethane } \\
\text { permeation rate thereafter of less than } \\
5 \mathrm{mg} / \mathrm{m}^{2} \cdot \mathrm{s} \text {. }\end{array}$ & $\begin{array}{l}\text { Dichloromethane breakthrough time of } \sim 5 \mathrm{~min} \\
\text { and dichloromethane permeation rate of } \sim 200 \\
\mu \mathrm{g} / \mathrm{cm}^{2} \cdot \mathrm{min}, \text { comparable to Saranex-coated } \\
\text { Tyvek fabric. }\end{array}$ \\
\hline \multicolumn{2}{|l|}{ 3. Fabric durability } \\
\hline $\begin{array}{l}\text { Suits have adequate flexibility, abrasion and } \\
\text { wear resistance to allow use for } 5-15 \text { days } \\
\text { before discarding. }\end{array}$ & $\begin{array}{l}\text { Suits have flexibility and durability comparable } \\
\text { to current chemical protective clothing. }\end{array}$ \\
\hline \multicolumn{2}{|l|}{ 4. Fabric manufacturability } \\
\hline $\begin{array}{l}\text { At least } 3-5 \text { sample rolls of this fabric, } 1 \mathrm{~m}(40 \\
\text { in) wide, } 100 \mathrm{~m} \text { (yd) long have been produced. }\end{array}$ & $\begin{array}{l}\text { Enough rolls of this fabric ( } 1 \mathrm{~m} \text { wide } \times 100 \mathrm{~m} \\
\text { long) have been produced to make } 10-20 \\
\text { prototype suits. }\end{array}$ \\
\hline \multicolumn{2}{|l|}{ 5. Suit manufacturability } \\
\hline $\begin{array}{l}\text { A cooperating manufacturing company has } \\
\text { been identified and } 10-15 \text { suits for laboratory } \\
\text { tests have been produced. }\end{array}$ & $\begin{array}{l}\text { A cooperating manufacturing company has } \\
\text { been identified and } 10-15 \text { suits for laboratory } \\
\text { tests have been produced. }\end{array}$ \\
\hline \multicolumn{2}{|l|}{ 6. Cost effectiveness of suit } \\
\hline $\begin{array}{l}\text { A technical and economic analysis of the fabric } \\
\text { and suit production process shows that suits } \\
\text { can be provided to the end users at a cost of } \\
\$ 10-30 \text { /suit. }\end{array}$ & $\begin{array}{l}\text { An economic analysis shows that the savings } \\
\text { due to higher worker productivity are greater } \\
\text { than the price difference between MTR and } \\
\text { lower-cost conventional suits. }\end{array}$ \\
\hline
\end{tabular}




\subsection{Outline of Phase I Research Plan}

The Phase I project had three major components: fabric optimization, commercial-scale fabric production, and prototype suit production and evaluation. An outline of each step is given below; details of the work are given in the following sections.

a) Fabric Optimization: Fabric optimization involved optimization of the individual layers included in the final protective fabric, and optimization of the way these layers are combined. The fabric components studied during the fabric optimization process were the support fabric, the sorbent layer (including the sorbent used, the polymer used, and the ratio of the two), and the permselective layer (including the polymer and post-treatment methods). We also studied the geometry used to combine the individual layers into the final protective fabric.

b) Commercial-Scale Fabric Production: Commercial-scale fabric production involved scaling up from the 12-inch-wide machines used during fabric optimization to 40-inch-wide machines. Outside suppliers of techniques and methods not available within MTR were identified as necessary. Rolls of 40 -inch-wide fabric at least $100 \mathrm{~m}$ long were required for use in prototype suit fabrication. A reliable method was developed for use in future commercial production.

c) Prototype Suit Production and Evaluation: A commercial protective clothing manufacturer (Kappler Safety Group, Gantesville, AL) was found to fabricate 10 to 15 prototype suits, to demonstrate the manufacturability of protective clothing made from our fabric. These prototype suits were evaluated under laboratory conditions for their comfort, durability, and protective characteristics. Finally an economic evaluation was performed to compare the value of increased worker productivity versus the cost of the suit. An estimate of the commercial potential of the fabric was made from the economic analysis and market estimates.

\section{EXPERIMENTAL PROCEDURES}

\subsection{Fabric Preparation}

Most of the fabric optimization program was performed at the laboratory scale, using 30$\mathrm{cm}$-wide fabric coating and casting machines. Details of the processes and equipment are given below.

The procedure for putting the sorbent layer onto the support fabric is called "casting"; a casting machine is illustrated in Figure 6. A film of casting slurry, consisting of sorbent suspended in a polymer solution in a water-miscible solvent, is doctored onto a moving belt of fabric. The fabric belt then passes into a water bath which precipitates the polymer and sorbent as a microporous film. The film produced has an asymmetric porous structure, with one side having pore diameters on the order of $0.5-5.0 \mu \mathrm{m}$ and the other consisting of a skin with very fine pores, on the order of 
0.01-0.02 $\mu \mathrm{m}$. The fabric is collected on a take-up roll, after which the support is washed, to remove any remaining solvent, and dried. Continuous rolls of fabric, up to 100 meters long, can be prepared. This process can be used with both woven and nonwoven fabrics, and with a variety of polymers. The viscosity of the polymer and speed of the fabric belt must be controlled to ensure the polymer is completely precipitated before being wound onto the take-up roll, and to ensure polymer does not bleed through the support fabric.

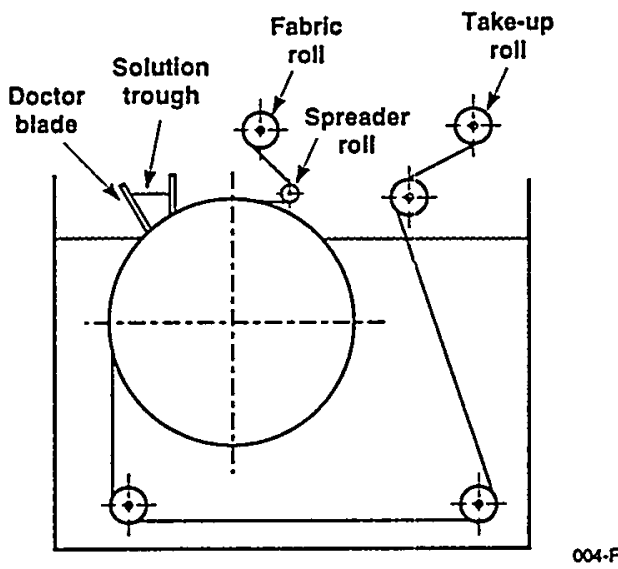

Figure 6. Schematic of the membrane casting machine used to prepare the sorbent-loaded microporous membrane on support fabric. Continuous rolls of fabric can be made by both the 30-cm (12-in) and the 1-m (40-in) machines.

After preparation of the sorbent-loaded sorptive layer, the permselective layer is applied by a coating technique using the coating machine illustrated in Figure 7. Support membrane from a feed roll passes through the coating tank, which contains a dilute solution of the polymer. The moving support membrane is coated with a liquid layer. After evaporation of the solvent in a drying oven, a thin polymer layer remains. The resulting composite material is wound onto a take-up roll. The thickness and number of defects in the permselective layer depend on the concentration and viscosity of the coating solution used and the nature of the microporous support film.

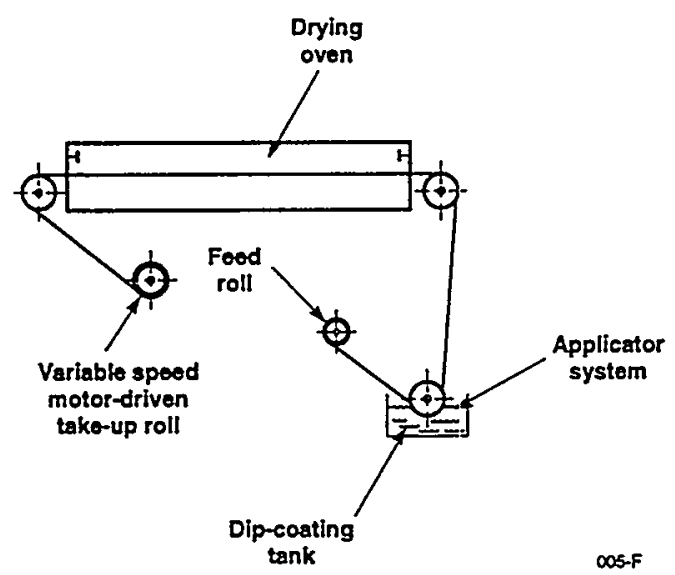

Figure 7. Schematic of a thin-film coating machine. 


\subsection{Test Procedures}

Quantitative and qualitative tests measuring key fabric properties were used to guide the fabric optimization program. The principal tests are listed in Table 6 . The most important tests are for water vapor transmission measured by moisture vapor transmission rate [MVTR] and organic vapor permeation. Other properties of the fabric, including sorbent capacity, gas permeation, weight, thickness, flexibility, and durability, were also determined. The tests used at MTR to evaluate trial fabric samples are described briefly below. The detailed procedures for measuring sorbent capacity, chemical vapor permeation, and MVTR are included in Appendix A.

Table 6. Tests Used to Evaluate Fabric and Clothing

\begin{tabular}{|c|c|}
\hline Criterion & Test Method Standard \\
\hline \multicolumn{2}{|l|}{ 1. Water vapor transmission } \\
\hline $\begin{array}{l}\text { Moisture water vapor transmission rate (MVTR) } \\
\text { Upward } \\
\text { Downward } \\
\text { Thermal manikin }\end{array}$ & $\begin{array}{l}\text { ASTM E96-94 } \\
\text { ASTM E96-94 } \\
\text { (inverted) }\end{array}$ \\
\hline \multicolumn{2}{|l|}{ 2. Chemical permeation } \\
\hline $\begin{array}{l}\text { Dichloromethane breakthrough time } \\
\text { Dichloromethane permeation rate }\end{array}$ & $\begin{array}{l}\text { ASTM F739-91 } \\
\text { ASTM F739-91 }\end{array}$ \\
\hline \multicolumn{2}{|l|}{ 3. Durability and physical properties } \\
\hline $\begin{array}{l}\text { Hydrostatic resistance } \\
\text { (before and after abrasion) } \\
\text { Grab breaking strength } \\
\text { - Elmendorf tear strength } \\
\text { - Flex durability } \\
\text { Weight } \\
\text { Thickness }\end{array}$ & $\begin{array}{l}\text { FTMS } 5512 \\
\text { FTMS } 5100 \\
\text { ASTM D1424 } \\
\text { ASTM F392 }\end{array}$ \\
\hline
\end{tabular}

ASTM: American Society for Testing of Materials

FSTM: Federal Test Method Standard

\section{Moisutre Vapor Transmission Rate (MVTR) Test}

The procedure used to measure the MVTR of the fabrics is based on ASTM E96-94. We modified the procedure slightly to use less expensive test containers and environmental control equipment; since we always used this test to compare different trial fabrics, strict adherence to the standard was not necessary. Aluminum cups 2.4 inches in diameter (essentially miniature "pie plates") are filled with $30 \mathrm{ml}$ of distilled water and sealed by gluing (with silicone rubber glue) a sample of fabric over the opening. The sealed containers are placed in a constant humidity chamber, 
maintained at $26^{\circ} \mathrm{C}$ and $50 \%$ relative humidity. The temperature and humidity are monitored regularly to ensure that they are constant. A fan is used to circulate air over the containers. The sealed containers are periodically weighed to assess the evaporative loss of water. Since the rate at which weight is lost from these containers represents the rate at which water vapor is permeating the fabric samples, the water vapor transmission rates can be calculated. The water vapor. transmission rate of the permselective layer and the sorbent layer can be determined independently by testing the fabric with and without the permselective layer added.

\section{Organic Vapor Permeation Test}

The ability of the fabric to limit permeation of harmful organic compounds was simulated in permeation tests with dichloromethane. We chose to use dichloromethane $\left(\mathrm{CH}_{2} \mathrm{Cl}_{2}\right)$ as our challenge chemical instead of using carbon tetrachloride $\left(\mathrm{CCl}_{4}\right)$ because it has advantages in comparing with other fabrics, for ease of measurement, and for safety reasons (see Table 7). Our test procedure is based on the ASTM-F739-91 test specification.

\section{Table 7. Reasons for Using Dichloromethane as Challenge Chemical}

Comparison to standard protective fabrics: Dichloromethane is included in the recommended list of chemicals in ASTM F1001-89 "Standard Guide for Selection of Chemicals to Evaluate Protective Clothing Materials", whereas $\mathrm{CCl}_{4}$ is not. For this reason, much more permeation data for protective fabrics exist for $\mathrm{CH}_{2} \mathrm{Cl}_{2}$ than for $\mathrm{CCl}_{4}$. By using $\mathrm{CH}_{2} \mathrm{Cl}_{2}$ as our routine test chemical, the performance of our fabrics can be readily compared with that of commercially available materials. In addition, because of its smaller molecular size, $\mathrm{CH}_{2} \mathrm{Cl}_{2}$ is a better challenge chemical than $\mathrm{CCl}_{4}$ in fabric optimization work.

Analytical detection system sensitivity: Our analytical detection system is based on the flameionization technique, in which the organics being analyzed are burned in a flame of hydrogen and air. This technique is not affected by the presence of water vapor in the sample, an important advantage for use in our fabric development program. The sensitivity of this detection system is proportional to the flammability of the organic, which, in turn, is proportional to the number of carbon-hydrogen bonds in the molecule. Since $\mathrm{CCl}_{4}$ has no $\mathrm{C}-\mathrm{H}$ bonds, its detection sensitivity by flame-ionization is rather poor. On the other hand, $\mathrm{CH}_{2} \mathrm{Cl}_{2}$ can be detected at concentrations in air as low as $0.5 \mathrm{ppmv}$. This level is over 20 times smaller than that required to measure the normalized breakthrough time required by ASTM F739-91.

Safety: Both $\mathrm{CCl}_{4}$ and $\mathrm{CH}_{2} \mathrm{Cl}_{2}$ are classified by NIOSH (National Institute for Occupational Safety and Health) as carcinogens. However, the 8-hour permissible exposure limit (PEL) and the immediately dangerous to life and health (IDLH) limit established by OSHA (Occupational Safety and Health Administration) for $\mathrm{CCl}_{4}$ are significantly lower than those for $\mathrm{CH}_{2} \mathrm{Cl}_{2}$, indicating that $\mathrm{CCl}_{4}$ poses a significantly higher health hazard than does $\mathrm{CH}_{2} \mathrm{Cl}_{2}$. The PEL and IDLH limits are 2 and 300 ppmv for $\mathrm{CCl}_{4}$ and 500 and 5000 ppmv for $\mathrm{CH}_{2} \mathrm{Cl}_{2}$, respectively. These values are reported in the 1990 edition of NIOSH Pocket Guide To Chemical Hazards. 
In the test procedure, a $20-\mathrm{cm}^{2}$ sample of fabric is mounted between two halves of a 2-inch Pesce permeation test cell (Pesce Lab Sales; Kennet Square, PA 19348) as shown in Figure 8. One side of the cell is filled with liquid dichloromethane. Any dichloromethane permeating the fabric to the other side of the cell is carried by a nitrogen sweep to the detector. Knowing the fabric area, the nitrogen sweep flow rate and the dichloromethane concentration, the chemical permeation rate can be calculated.

Some polymers evaluated for the selective layer are affected by water (their permeation properties change depending on the amount of water vapor present). Therefore, in some tests, the nitrogen sweep was bubbled through water to humidify it before it entered the test cell, to more realistically simulate the environment inside a worker's suit. Although not measured, we estimate that the relative humidity of the nitrogen sweep was greater than $90 \%$.

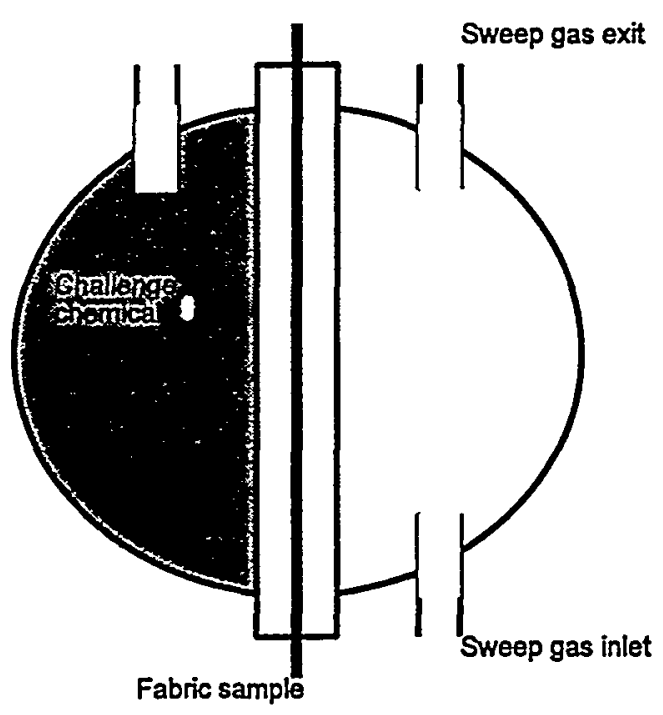

Figure 8. Diagram of apparatus for testing permeation resistance.

\section{Sorbent Capacity Test}

The sorbent capacity for organic vapor is also a useful measure of fabric performance. Static sorption tests, to determine the effect of the processing steps on the sorbent, were carried out from time to time. It is known that the sorbent particles typically lose some of their activity during processing, due to encapsulation by the polymer or deactivation by process conditions and solvents. Since this could decrease the protection afforded by the fabric, it is desirable to avoid or minimize any loss in sorbent activity.

The static sorption test consists of measuring the intrinsic sorption capacity of virgin sorbent and comparing it with the sorption capacity of the sorbent-loaded membrane at the end of each processing step. A known weight of sorbent or sorbent-loaded fabric is placed in a sample vessel, which is introduced into an atmosphere saturated with carbon tetrachloride vapor. (Carbon 
tetrachloride was used because it is the industry standard used for evaluating sorbent capacities.) After a predetermined exposure, the sample vessel is removed and weighed. Because the increase in weight is due to carbon tetrachloride uptake by the sorbent, the sorption capacity can be determined.

\section{Gas Permeation Measurement}

The apparatus shown in Figure 9 was used to determine permeation of gases through the fabric. We used oxygen and nitrogen as the test gases for this study, primarily to test for permselective layer integrity (absence of defects) and thickness. The test sample is mounted in a permeation cell and all of the lines are purged with the test gas. One side of the sample is then pressurized to $50 \mathrm{psig}$ with the test gas and the other is kept at atmospheric pressure. The flow rate of the permeating gas is measured with a flowmeter and the pressure-normalized flux is calculated. The gas is then purged from the cell, the lines are purged with a second test gas, and the procedure is repeated.

Integrity of the permselective layer is determined by comparing the oxygen/nitrogen flux ratio with the known value for the oxygen (nitrogen flux ratio with the known value for the permselective polymer. Thickness of the permselective layer (rather than the fabric thickness) is determined by comparing the flow rate of oxygen (or nitrogen) through the membrane with that of a standard film of known thickness of the same polymer.

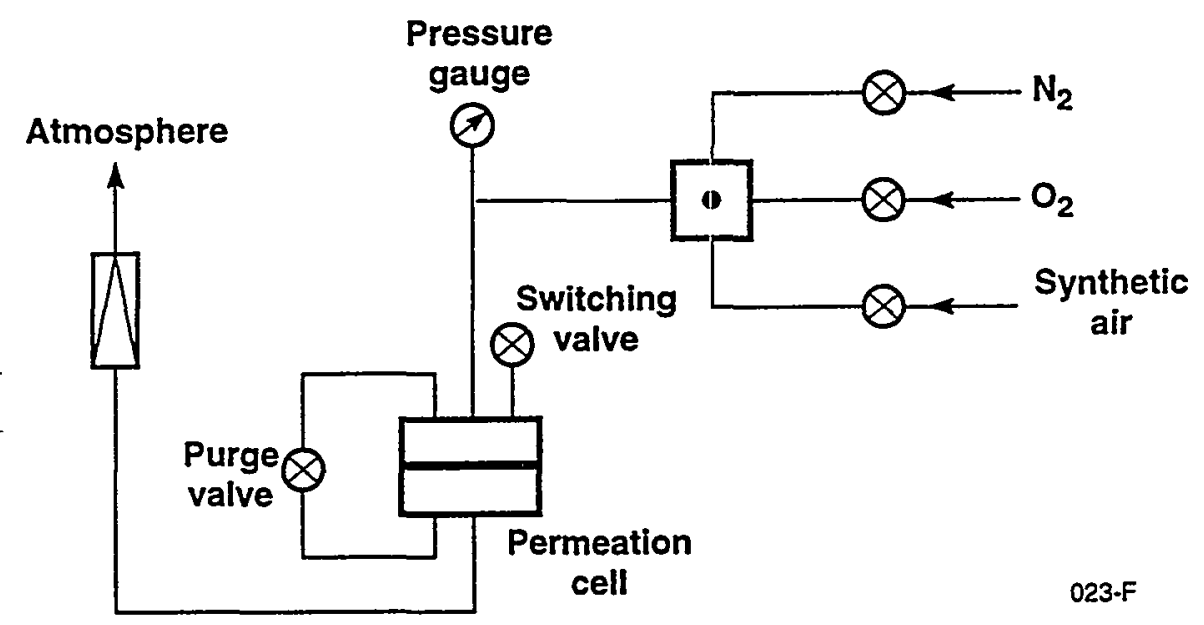

Figure 9. Diagram of gas permeation apparatus for testing composite fabrics. 


\section{Fabric Weight}

Fabric weight was determined by averaging the weight of five fabric samples, each measuring $10 \mathrm{~cm} \times 10 \mathrm{~cm}\left(100 \mathrm{~cm}^{2}\right)$.

\section{Fabric Thickness}

Fabric thickness was determined using a Mitutoyo Dial Thickness Gauge.

\section{Mechanical Properties (Adhesion, Durability, Flatness, Flexibility)}

To help guide our fabric optimization process, we devised a qualitative procedure to evaluate the mechanical properties of the fabrics. Four properties-adhesion, durability, flatness, and flexibility-were evaluated on a scale of 1 to 5,1 being the worst and 5 being the best. As shown in Table 8, discrete steps in these scales define the qualities of the fabric clearly, so that samples can be compared without the expense of quantitative testing by an outside laboratory.

Table 8. Grading System Used to Rate Mechanical Properties of Coated Fabrics

\begin{tabular}{|l|l|l|l|l|l||}
\hline Property & \multicolumn{1}{|c|}{1 - (worst) } & \multicolumn{1}{|c|}{$\mathbf{2}$} & \multicolumn{1}{|c|}{$\mathbf{3}$} & \multicolumn{1}{|c|}{$\mathbf{4}$ - (best) } \\
\hline Adhesion & $\begin{array}{l}\text { Sorbent layer } \\
\text { peels off by itself. }\end{array}$ & $\begin{array}{l}\text { Sorbent layer } \\
\text { peels easily from } \\
\text { a non-edge. }\end{array}$ & $\begin{array}{l}\text { Sorbent layer } \\
\text { peels easily from } \\
\text { an edge-with } \\
\text { difficulty from a } \\
\text { non-edge. }\end{array}$ & $\begin{array}{l}\text { Sorbent layer } \\
\text { difficult to peel } \\
\text { off from an } \\
\text { edge. }\end{array}$ & $\begin{array}{l}\text { Sorbent layer } \\
\text { impossible to } \\
\text { peel off. }\end{array}$ \\
\hline Durability & $\begin{array}{l}\text { Sorbent layer } \\
\text { brittle and } \\
\text { crumbly. }\end{array}$ & $\begin{array}{l}\text { Sorbent layer } \\
\text { breaks if folded } \\
\text { severely. }\end{array}$ & $\begin{array}{l}\text { Sorbent layer } \\
\text { can be creased } \\
\text { but not broken } \\
\text { by folding. }\end{array}$ & $\begin{array}{l}\text { Sorbent layer } \\
\text { difficult to } \\
\text { crease by } \\
\text { folding. }\end{array}$ & $\begin{array}{l}\text { Sorbent layer } \\
\text { sturdy and very } \\
\text { difficult to tear } \\
\text { apart. }\end{array}$ \\
\hline Flatness & $\begin{array}{l}\text { Fabric curls on } \\
\text { itself completely. }\end{array}$ & $\begin{array}{l}\text { Fabric curls on } \\
\text { itself at edges. }\end{array}$ & $\begin{array}{l}\text { Fabric bends at } \\
\text { edges. }\end{array}$ & $\begin{array}{l}\text { Fabric mostly } \\
\text { flat. }\end{array}$ & $\begin{array}{l}\text { Fabric } \\
\text { completely flat. }\end{array}$ \\
\hline Flexibility & $\begin{array}{l}\text { Fabric as flexible } \\
\text { as Blue Max suit. }\end{array}$ & $\begin{array}{l}\text { Fabric as flexible } \\
\text { as Barricade. }\end{array}$ & $\begin{array}{l}\text { Fabric as } \\
\text { flexible as } \\
\text { Saranex-coated } \\
\text { Tyvek. }\end{array}$ & $\begin{array}{l}\text { Fabric as } \\
\text { flexible as pure } \\
\text { PVDF/nylon. }\end{array}$ & $\begin{array}{l}\text { Fabric as } \\
\text { flexible as bare } \\
\text { nylon fabric. }\end{array}$ \\
\hline
\end{tabular}

Adhesion tests evaluate how well the various polymer layers stick to each other. Obviously, the layers must not delaminate while the suit is in use. Adhesion was determined by testing the ease of pulling the polymer layer off the support fabric. Some polymers spontaneously delaminated from the fabric (worst), whereas others could not be separated at all (best).

Durability tests measured the damage resulting to the polymer layer due to folding and wrinkling of the fabric. Some polymers would crumble when the fabric was bent less than $90^{\circ}$ (worst), whereas others would not even retain a crease after being folded $180^{\circ}$. 
Flatness is an important indication of the ease with which the fabric can be produced and subsequently manufactured into suits; a fabric that curls on itself is very difficult to work with. Some coated fabric curled into a tight cylinder as soon as the polymer layer was dried (worst), whereas others showed no tendency to curl at all (best).

Flexibility is important to the comfort of the final suit. If the fabric is not flexible, the suit will be uncomfortable to wear and difficult to move in. We evaluated flexibility by comparing a sample fabric to a set of standard fabrics. These standard fabrics included commercially available chemical protective fabrics (worst to moderate), one of our coated fabrics (without sorbent added to the polymer), and an uncoated woven nylon fabric (best).

\section{FABRIC OPTIMIZATION}

\subsection{Objective}

The objective of this task was to develop an optimized fabric formulation using laboratoryscale equipment. Optimization at the laboratory scale rather than commercial scale allowed us to produce more samples and to evaluate them more quickly. The fabric attributes we attempted to optimize included (1) resistance to chemical permeation, (2) water vapor transmission rate, (3) physical comfort characteristics (flexible, light weight, good drape and tactile properties), and (4) durability.

Unfortunately, these properties are not independent, and any fabric is a compromise between these four attributes. For example, many protective fabrics provide a high degree of chemical protection (Barricade, Tychem, etc.-see Appendix B), but the layer that prevents chemical permeation vapor also prevents water vapor transmission, causing the suits to be very hot. The layers providing chemical resistance are often thick and stiff; consequently, the suit is physically uncomfortable. Despite these drawbacks, when chemical hazards are present these suits must be used. At the other extreme are suits that are light, flexible, and permit water vapor transmission - in other words, are comfortable to wear (Tyvek, Comfort-gard, etc.). However, they provide no chemical resistance and can only be used for protection against particles.

Thus, the primary goal of this task was to develop a fabric that provides both chemical protection and water vapor transmission, which inevitably requires a trade off. In addition, even if a fabric provides both high chemical resistance and water vapor transmission, it is useless for protective clothing if it does not have adequate physical and durability properties. These characteristics were also considered during our optimization process. A number of components of our fabric can be varied, to affect its combination of attributes. These components are listed in Table 9, and are described briefly below and in detail in Sections 5.2 and 5.3. 
Table 9. Fabric Components Studied During the Fabric Optimization Process.

\begin{tabular}{|c|c|}
\hline Parameter & Range \\
\hline Support Fabric & $\begin{array}{l}\text { Woven } \\
\text { Non-woven }\end{array}$ \\
\hline $\begin{array}{l}\text { Sorptive layer } \\
\text { Polymer } \\
\text { Sorbent material } \\
\text { Sorbent loading }\end{array}$ & $\begin{array}{l}\text { PVDF or polyurethane } \\
\text { Carbon or Zeolite } \\
0 \text { to } 60 \mathrm{wt} \% ; 0-25 \mathrm{~g} / \mathrm{m}^{2}\end{array}$ \\
\hline $\begin{array}{c}\text { Permselective Layer } \\
\text { Polymer } \\
\text { Thickness } \\
\text { Post-treatments }\end{array}$ & $\begin{array}{l}\text { Various grades } \\
1-10 \mu \mathrm{m} \\
\text { Various cross-linking agents }\end{array}$ \\
\hline Protective Layer & Silicone rubber, lamination \\
\hline Geometry & Four different ways of combining layers \\
\hline
\end{tabular}

Permselective Layer: The permselective layer is the heart of our fabric. This layer allows selective permeation (hence "permselective") of some compounds (in this case, water vapor) while hindering the permeation of other compounds (in this case, organic chemicals). To allow a significant water vapor permeation rate (also termed moisture vapor transmission in the protective clothing industry), the permselective layer must be very thin (typically between 1 and $10 \mu \mathrm{m}$ ), but it must also be free of any defects (i.e., small holes) if it is to prevent permeation of chemicals. The polymer used in the permselective layer must be resistant to chemical permeation, must allow water vapor transmission, must be coatable as a thin defect-free layer, and must be durable and flexible. To optimize this layer, we examined a variety of polymers and polymer grades, a range of thicknesses, the coating procedures, and the post-treatment methods.

Sorptive Layer: The sorptive layer serves two purposes in our fabric: a support on which to coat the permselective layer and a matrix to hold the sorbent materials. A support layer is needed because the permselective layer is thin and fragile. For this support we use a microporous polymeric membrane that allows transmission of water vapor (and organic chemicals) through its pores. These pores must be small enough that defects do not form in the permselective layer during coating. The properties required of a good support material include castability (the casting procedure was described in Section 4), durability and flexibility, and resistance to chemical attack. We evaluated several polymers and polymer grades and different casting conditions to optimize the support function of the sorbent layer.

The second function of the sorptive layer is to hold the sorbent material. The sorbent provides a second defense against chemical permeation-any chemical that does permeate the permselective layer will be captured by the sorbent. Sorbents are solid materials that attract and hold selected compounds; typical sorbents include zeolites (molecular sieves), silica gel, and 
activated carbon. The ideal material will adsorb organic chemicals but not water, and will not affect the physical properties of the fabric (color, flexibility, strength, durability, weight, etc.). We evaluated a variety of sorbent materials and grades, and evaluated different loadings (from 0 to $63 \%$ of the total weight of the sorbent layer) to optimize this sorbent layer.

Support Fabric: The support fabric supports the permselective and sorbent layers during manufacture, and provides strength and durability to the final product. The ideal support is light, flexible, breathable, and durable, and has a pleasant appearance and feel. We examined a variety of woven and nonwoven fabrics for this layer.

Protective Layer: If the permselective layer is outside the support and sorbent layers, this thin fragile layer is exposed to abrasion and other physical abuse. The ideal protective layer is flexible, light, and durable, but will not hinder water vapor transmission. Several approaches to protecting the permselective layer from physical damage were examined.

\subsection{Summary of Results of Fabric Optimization}

The results of our fabric optimization work are summarized in this section. Details of the optimization process for each layer of the fabric are described in the following section.

During the project, we developed two fabrics-MTR-1 and MTR-2 - that combine the four attributes described above. Figure 10 shows a diagram of MTR-2, which is a laminate of two identical, composite fabrics that we refer to as permselective fabric. The two permselective fabrics are laminated by joining the permselective layers, leaving the woven support fabric on both the outer and inner surfaces of the complete protective fabric (or laminated fabric). This approach ensures that the permselective layer is protected. MTR-1 consists of one permselective fabric layer laminated to a nonwoven fabric, which forms the inside layer of the resulting fabric. Thus, MTR-1 is more comfortable but less protective than MTR-2. Both fabrics combine moderate chemical permeation resistance, moderate water vapor transmission, and good physical properties and durability. .

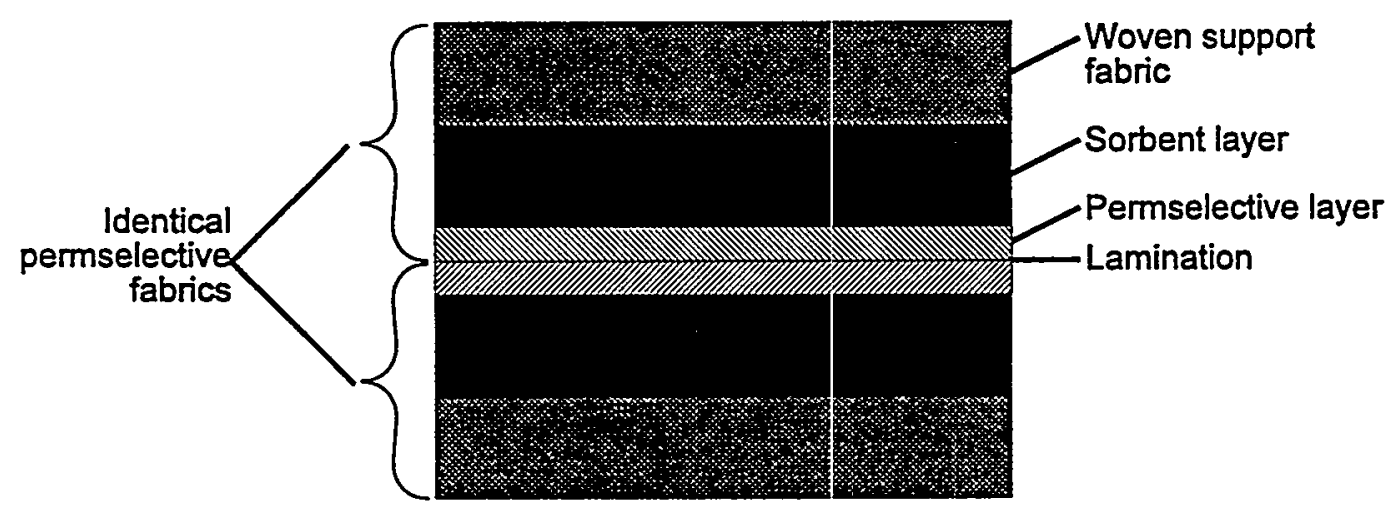

Figure 10. Structure of MTR-2 protective clothing fabric. MTR-1 is a laminate of one permselective fabric to a nonwoven fabric. 
Long-term degradation of the materials used in our fabric was not examined explicitly during this project. However, chemical permeation tests were carried for as long as 72 hours in some instances, with no indication of degradation. Since protective suits are designed to be used for hours or days at most, we believe long-term chemical degradation will not be a concern.

Table 10 summarizes the final choice of materials and processes used to prepare the laminated fabric, and Figure 11 shows the steps involved.

Table 10. Summary of Finalized Protective Fabric Materials

\begin{tabular}{||l|c|l||}
\hline \multicolumn{1}{|c|}{ Layer } & Formation Process & \multicolumn{1}{c|}{ Material Specifications } \\
\hline Support fabric & - & Ripstop nylon (HLC Dover style 7020 \#1) \\
\hline Sorbent layer (wet) & Solution casting & Casting solution: \\
& & 17 wt\% Pellethane 2103-80AEF \\
& & $17 \mathrm{wt} \%$ zeolite 13x (1 - 3 mm particle size) \\
& & Solvent: dimethyl acetamide (DMAc) \\
\hline Sorbent layer & Drying & Hot air drying \\
\hline Permselective & Dip coating & Coating/laminating solution: \\
layer/lamination & & 8 wt\% polyvinyl alcohol (Airvol 425) \\
& & $1.6 \%$ Cymel 385 \\
& & Solvent: water \\
\hline
\end{tabular}




$$
\text { Step Layer Added Structure Name }
$$

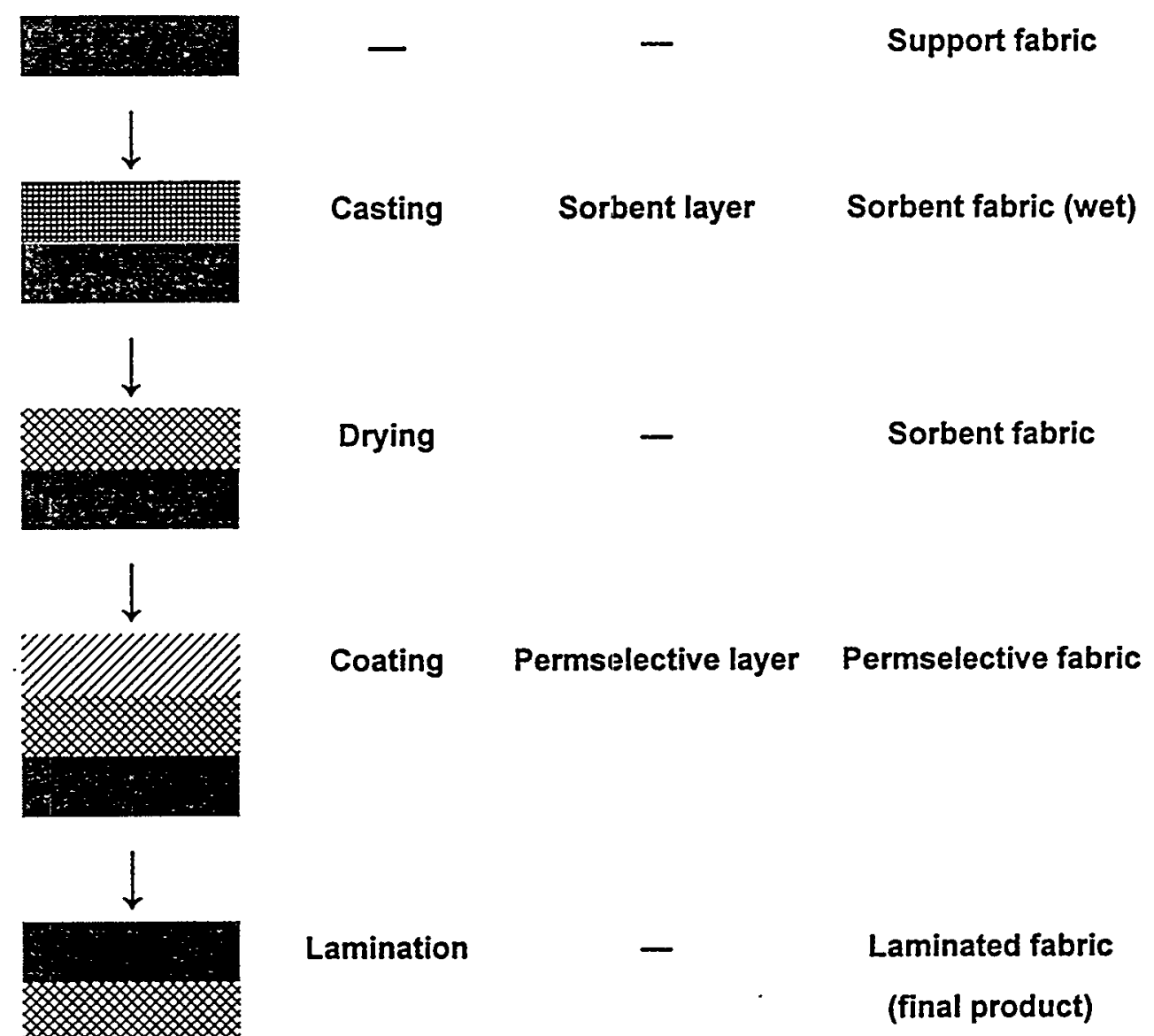

Figure 11. Schematic of manufacturing steps for protective fabric.

The starting point shown in Figure 11 is a woven support fabric. The first step is to cast the sorbent layer onto the support fabric. The microporous sorbent layer consists of a sorbent (zeolite) dispersed in a polymer (polyurethane). After casting, the sorbent layer is dried at $75^{\circ} \mathrm{C}$ for 10 minutes.

After the sorbent layer has been cast and dried, the resulting two-layer fabric (sorbent fabric) is coated with the permselective polymer. The sorbent fabric is dip coated with a polyvinyl alcohol 
solution (see Table 10 for the exact composition) and dried $\left(\sim 10\right.$ minutes at $\left.100^{\circ} \mathrm{C}\right)$. The resulting three-layer fabric is called the permselective fabric.

The permselective fabric could now perform as a protective fabric, but the exposed permselective layer would be easily damaged. To protect the permselective layer, two identical pieces of permselective fabric are laminated permselective layer to permselective layer (see Figure 10). This laminating step is done by wetting one piece of permselective fabric with an aqueous solution of the crosslinking agent, pressing it to the other piece of permselective fabric, and drying at $130^{\circ} \mathrm{C}$. This laminated fabric is the final product for use in protective clothing.

The properties of the two fabrics, MTR-1 and MTR-2, are compared with those of commercially available protective fabrics in Table 11 .

Table 11. Properties of MTR and Commercially Available Protective Fabrics

\begin{tabular}{||l|c|c|c|c|c||}
\hline \multicolumn{1}{|c|}{ Property. } & MTR-1 & MTR-2 & Tyvek & $\begin{array}{c}\text { Saranex- } \\
\text { Coated } \\
\text { Tyvek }\end{array}$ & Barricade \\
\hline $\begin{array}{l}\text { Chemical } \\
\text { (dichloromethane) } \\
\begin{array}{l}\text { Permeation } \\
\left(\mu g / \mathrm{cm}^{2} \cdot \min \right)\end{array}\end{array}$ & 440 & 165 & high & 120 & $<0.1$ \\
\hline $\begin{array}{l}\text { Water Vapor } \\
\text { Transmission } \\
(\text { MVTR) } \\
\text { (g/m².day) }\end{array}$ & $800-1,200$ & $800-1,300$ & $1,000-2,000$ & 0 & 0 \\
\hline Thickness (mils) & 10 & 8 & 8 & 10 & 21 \\
\hline Weight (oz/sq yd) & 6 & 6 & 1 & 4 & 5 \\
\hline
\end{tabular}

\subsection{Details of Fabric Optimization Process}

\subsubsection{Support Fabric}

We examined a number of materials, both woven and non-woven, for use as the support fabric. The ideal support fabric should be stiff enough that it does not wrinkle under tension during casting, but soft enough to be comfortable as clothing. It should also be smooth, lightweight, and inexpensive. Our final choice was a woven, ripstop nylon, which had the best combination of manufacturability, flexibility and wearability, and cost. Woven fabrics have superior flexibility and durability to non-wovens, although they are more expensive. The ripstop nylon was chosen from the woven fabrics because of its strength and light weight $(1 \mathrm{oz} / \mathrm{yd})$. Details of the support fabric selection process are discussed below. 


\section{Woven Fabric}

We obtained samples of 15 different woven fabrics; sorbent layers (50\% polyvinylidene fluoride, $50 \%$ activated carbon) were cast onto the seven most promising of these fabrics. In contrast to those on non-woven fabrics, the sorbent layers cast on the woven supports exhibited. better and more consistent mechanical and permeation properties. Only the HLC style 200D fabric was unsatisfactory because the sorbent layer did not adhere to it. In general, sorbent layers on the lighter fabrics were more flexible and mechanically stronger, whereas the sorbent layers on the heavier fabrics were flatter and easier to coat. Of the seven woven fabrics tested, two met our requirements: a nylon (HLC Dover Duke) and a ripstop nylon (HLC Dover Style 7020 \#1). The ripstop nylon (HLC Dover Style 7020 \#1) was our first choice because of its light weight. Table 10 outlines the properties of the woven fabrics and the reasons for our fabric choices. 
Table 12. Mechanical Properties of Coated Woven Fabrics

\begin{tabular}{|c|c|c|c|c|c|c|c|}
\hline $\begin{array}{l}\text { Support Fabric } \\
\text { Manufacturer } \\
\text { and Style \# }\end{array}$ & $\begin{array}{c}\text { Support } \\
\text { Fabric } \\
\text { Material }\end{array}$ & $\begin{array}{c}\text { Support } \\
\text { Fabric } \\
\text { Weight } \\
\left(\mathrm{g} / \mathrm{m}^{2}\right)\end{array}$ & $\begin{array}{l}\text { Mechanical } \\
\text { Strength } \\
\text { (1-5 scale) }\end{array}$ & $\begin{array}{c}\text { Flatness } \\
\text { (1-5 scale) }\end{array}$ & $\begin{array}{l}\text { Flexibility } \\
\text { (1-5 scale) }\end{array}$ & $\begin{array}{c}\text { Cost } \\
\text { (\$/yd) }\end{array}$ & $\begin{array}{c}\text { Reason for } \\
\text { Selecting/Not } \\
\text { Selecting } \\
\text { Fabric }\end{array}$ \\
\hline $\begin{array}{l}\text { Precision Fabrics } \\
\text { Group (PFG) } \\
\begin{array}{l}\# 181-007714 \mathrm{~s} / \\
56011\end{array}\end{array}$ & polyester & 83 & 2 & 4 & 2 & 1.98 & $\begin{array}{l}\text { Too stiff and } \\
\text { thick }\end{array}$ \\
\hline $\begin{array}{l}\text { PFG } \\
\# 181-012592 \mathrm{~s} / \\
56711\end{array}$ & polyester & 85 & 3 & 5 & 3 & 2.22 & $\begin{array}{l}\text { Heavier than } \\
\text { desirable }\end{array}$ \\
\hline $\begin{array}{l}\text { HLC Dover } \\
\text { style } 7020^{\circ \# 1}\end{array}$ & $\begin{array}{l}\text { ripstop } \\
\text { nylon }\end{array}$ & 40 & 4 & 4 & 3 & 1.95 & $\begin{array}{l}\text { Choice\#1: } \\
\text { light, smooth, } \\
\text { and sorbent } \\
\text { layer has } \\
\text { good } \\
\text { mechanical } \\
\text { strength }\end{array}$ \\
\hline $\begin{array}{l}\text { PFG } \\
\# 181-007892 \mathrm{~s} / \\
53266\end{array}$ & nylon & 42 & 5 & 3 & 3 & 2.71 & $\begin{array}{l}\text { Too thin to } \\
\text { hold tension } \\
\text { while casting }\end{array}$ \\
\hline $\begin{array}{l}\text { PFG } \\
\text { \#209-937212 s/ } \\
64183\end{array}$ & polyester & 67 & 4 & 4 & 2 & 5.24 & $\begin{array}{l}\text { Too } \\
\text { expensive }\end{array}$ \\
\hline $\begin{array}{l}\text { HLC Dover } \\
\text { Duke }\end{array}$ & nylon & 80 & 5 & 3 & 3 & 1.75 & $\begin{array}{l}\text { Choice \#2: } \\
\text { similar to } \\
\text { choice \#1, but } \\
\text { slightly } \\
\text { heavier and } \\
\text { more coarsely } \\
\text { woven }\end{array}$ \\
\hline $\begin{array}{l}\text { HLC Dover } \\
\text { style 200D }\end{array}$ & nylon & 114 & 1 & 4 & 3 & 1.75 & $\begin{array}{l}\text { Sorbent layer } \\
\text { delaminated } \\
\text { from fabric } \\
\text { immediately }\end{array}$ \\
\hline
\end{tabular}

\section{Non-Woven Fabric}

Since non-woven fabrics dominate the protective clothing industry, we obtained about a dozen samples of such materials for evaluation. Sorbent layers (50\% polyvinylidene fluoride, $50 \%$ activated carbon) were cast onto the four most promising of these fabrics. Table 13 summarizes the properties of the resulting coated fabrics. Surface smoothness is a good indicator of the coatability of the matrix by a permselective layer. Bleed-through, which occurs when the sorbent/polymer 
solution seeps through to the back of the support fabric, prevents formation of a smooth coatable microporous membrane top layer. Only one of the non-woven fabrics, Webril 141-583, resulted in an acceptable, coatable sorbent layer. However, the woven fabrics described above proved to have superior overall properties.

Table 13. Mechanical Properties of Coated Fabrics Using Non-Woven Support Fabrics

\begin{tabular}{||l|c|c|c|c||}
\hline $\begin{array}{c}\text { Fabric } \\
\text { Manufacturer } \\
\text { and Style \# }\end{array}$ & $\begin{array}{c}\text { Fabric } \\
\text { Material }\end{array}$ & $\begin{array}{c}\text { Matrix } \\
\text { Surface } \\
\text { Appearance }\end{array}$ & $\begin{array}{c}\text { Bleedthrough } \\
\text { Problems } \\
\text { (y/n) }\end{array}$ & $\begin{array}{c}\text { Flexibility } \\
\text { (1 - worst, 5 - best) }\end{array}$ \\
\hline $\begin{array}{l}\text { Freudenberg } \\
\text { FO 2401 }\end{array}$ & polyester & $\begin{array}{c}\text { smooth with } \\
\text { some bubbles }\end{array}$ & yes & 2 \\
\hline Reemay 2016 & polyester & $\begin{array}{c}\text { rough; fabric } \\
\text { nap visible }\end{array}$ & yes: severe & 3 \\
\hline $\begin{array}{l}\text { Webril M 141- } \\
034\end{array}$ & nylon & $\begin{array}{c}\text { fabric fibers } \\
\text { visible }\end{array}$ & yes & 3 \\
\hline $\begin{array}{l}\text { Webril } \\
141-583\end{array}$ & polypropylene & smooth & no & 3 \\
\hline
\end{tabular}

\subsubsection{Sorbent Layer}

Optimizing the sorbent layer involved three parameters: the sorbent material, the polymer material forming the matrix, and the sorbent loading and thickness of the layer. The optimum combination was a zeolite sorbent, polyurethane matrix polymer, and a loading of $50 \mathrm{wt} \%$ zeolite with a sorbent layer thickness of approximately 2 mils. Zeolite was chosen over activated carbon primarily because the resulting fabric was white rather than black. Polyurethane was chosen for the polymer matrix because of its superior flexibility and durability over polyvinylidene fluoride. A $50 \%$ loading of zeolite proved to be close to the maximum loading before the physical properties of the fabric (flexibility and durability) began to degrade. Details of the sorbent layer optimization process are discussed below.

\section{Sorbent Material}

For the sorbent we evaluated various types of activated carbons and zeolites. The activated carbons are less expensive, have a higher capacity for organic compounds, and adsorb compounds over a wider range of molecular weights than do zeolites. However, organic compound permeation and water transmission tests showed no significant difference between the performance of fabrics made with carbon or zeolite. Thus carbon's advantages are outweighed by the fact that fabrics containing carbon are black, an undesirable color to wearers of protective clothing, whereas fabrics containing zeolite are white. 
Initially we evaluated sorbents by comparing the carbon tetrachloride adsorption capacity of the sorbents incorporated into a polymer matrix. We cast a series of sorbent layers containing different sorbents onto support fabrics. The sorbent layer consisted of a polyvinylidene fluoride (PVDF) polymer matrix containing the sorbent materials; all were cast with a PVDF: sorbent ratio of $1: 1$. The sorbent loading $\left(\mathrm{g} / \mathrm{m}^{2}\right)$ was determined by weighing a $10 \mathrm{~cm}$ by $10 \mathrm{~cm}$ piece of the sample and subtracting the weight of the nylon support fabric $\left(71 \mathrm{~g} / \mathrm{m}^{2}\right)$. Table 14 shows the sorbent capacity as cast fabrics and their pure sorbent (not cast in a polymer) capacity. In general, the carbons had much higher capacities than zeolites, and the cast sorbents showed reduced capacity over the pure sorbent capacities. With one sample (206.11.1; activated carbon) we tested the effect of coating the sorbent layer with the permselective layers we expected to use later. The results show that these additional permselective layers did not change the sorbent capacity. Physical evaluation showed that the sorbent material had little influence on fabric properties compared to the influence of polymer material, support fabric, and sorbent loading.

Based on these results, we continued our fabric optimization using the best carbon and best zeolite. Calgon PCB-G was used as the activated carbon because of its high capacity, reliable availability and low price, and its current use in U.S. Army chemical protective clothing; for the zeolite we used Zeochem $13 x$ because of its higher capacity. The carbon had much higher capacity than the zeolite, but the black color of the fabric was a serious drawback. According to our contacts in the protective clothing industry, black is an undesirable color for protective clothing because it makes the wearer feel claustrophobic and absorbs heat from the sun. The effectiveness of both carbon and zeolite in complete fabrics (including the permselective layer) against permeation of dichloromethane was tested. 
Table 14. Adsorption Capacities of Sorbent Layers and Pure Sorbents

\begin{tabular}{|c|c|c|c|c|c|}
\hline Sample ID & $\begin{array}{c}\text { Sorbent } \\
\text { Manufacturer }\end{array}$ & $\begin{array}{l}\text { Sorbent } \\
\text { Grade }\end{array}$ & $\begin{array}{c}\text { Sorbent } \\
\text { Loading } \\
\left(\mathrm{g} / \mathrm{m}^{2}\right)\end{array}$ & \begin{tabular}{|c|} 
Pure \\
Sorbent \\
Sorption \\
Capacity \\
$\left(\mathrm{g}_{\mathrm{CCl} 14} / \mathrm{g}_{\text {sorben }}\right)$ \\
\end{tabular} & $\begin{array}{c}\text { Matrix } \\
\text { Sorption } \\
\text { Capacity } \\
\left(\mathrm{g}_{\mathrm{CCl} 4} / \mathrm{g}_{\text {sorbent }}\right)\end{array}$ \\
\hline \multicolumn{6}{|c|}{ Activated Carbons } \\
\hline 206.6 .1 & Norit & SA Plus & 51 & 0.59 & 0.28 \\
\hline 206.6 .2 & Elf Atochem & $\begin{array}{c}\text { Acticarbone } \\
2 \mathrm{~S}\end{array}$ & 53 & 0.66 & 0.38 \\
\hline 206.6 .3 & Elf Atochem & $\begin{array}{l}\text { Acticarbone } \\
\text { ENO }\end{array}$ & 55 & 1.58 & 0.59 \\
\hline 206.6 .4 & Elf Atochem & PAC 200 & 53 & 0.54 & 0.35 \\
\hline 206.6 .5 & Calgon Carbon Co. & WPH & 48 & 0.25 & 0.25 \\
\hline 206.6 .6 & Calgon Carbon Co. & WPL & 46 & 0.24 & 0.27 \\
\hline 206.6 .8 & Calgon Carbon Co. & PCB-G & 48 & 0.36 & 0.37 \\
\hline $\begin{array}{c}206.11 .1 \\
\text { uncoated } \\
\text { PVA coat } \\
\text { PVA + SR } \\
\text { coats } \\
\end{array}$ & Calgon Carbon Co. & PCB-G & $\begin{array}{l}40 \\
40 \\
40\end{array}$ & $\begin{array}{l}0.61 \\
0.61 \\
0.61\end{array}$ & $\begin{array}{l}0.50 \\
0.47 \\
0.48\end{array}$ \\
\hline \multicolumn{6}{|l|}{ Zeolites } \\
\hline 206.9 .5 & UOP & $s-115$ & 39 & 0.10 & 0.07 \\
\hline 206.9 .6 & UOP & Smellrite & 40 & 0.17 & 0.07 \\
\hline 206.11 .2 & Zeochem & $13 x$ & 32 & 0.19 & 0.18 \\
\hline
\end{tabular}

\section{Polymer Matrix}

For the polymer used in the sorptive layer, we examined several grades of two different polymers: polyvinylidene fluoride (PVDF) and polyurethane. (In earlier studies polysulfone was also examined but was ruled out due to stiffness.) PVDF (Kynar, Atochem, Philadelphia, PA) has excellent chemical resistance ${ }^{1}$, but only moderate flexibility, and low durability. Polyurethane, on the other hand, is very flexible and durable, and has acceptable chemical resistance. Based on these

1 Chemical resistance refers here to physical or chemical degradation of the polymer due to contact with a particular chemical compound, not to resistance to permeation of a compound through the polymer. The polymer used in the sorbent layer, which is microporous, does not need to have high permeation resistance because it is meant only to support the sorbent, not to prevent passage of permeating compounds. 
considerations, we chose a polyurethane, Pellethane 2103-AEF, as the polymer used in the sorbent layer. A number of selection criteria were used, including

- coatability/compatibility of the polymer with the permselective layer,

- sorbent capacity and activity,

- mechanical properties (adhesion, mechanical strength, flatness, and flexibility),

- permeability, and

- chemical resistance.

The properties of sorbent layers made with various PVDF and polyurethane polymers were evaluated by machine-casting a 1:1 polymer/carbon mixture (using Calgon PCB-G activated carbon) on woven nylon fabric. The mechanical properties of these fabrics are given in Table 15 . The nitrogen flux values are an indication of the openness of the sorbent layer; a more porous layer (higher nitrogen flux) is better because it will allow higher rates of water vapor transmission. Higher measures for flexibility and flatness are also desirable. From the table it is apparent that, in terms of these properties, the polyurethanes (except Pellethane 2103-55D) are superior. In particular, Pellethane 2103-80AEF had the best properties of all polymers tested. All sorbent layers could be acceptably coated with permselective layers; thus, this consideration did not eliminate either polymer. 
Table 15. Mechanical Properties of PVDF and Polyurethane Sorbent-Containing Fabrics (1:1 Polymer/Carbon ratio)

\begin{tabular}{|c|c|c|c|c|}
\hline $\begin{array}{l}\text { Sample } \\
\text { ID }\end{array}$ & $\begin{array}{l}\text { Polymer Used in } \\
\text { Sorbent Layer }\end{array}$ & $\begin{array}{l}\text { Nitrogen Flux } \\
\left(\mathrm{cm}^{3}(\mathrm{STP}) /\right. \\
\left.\mathrm{cm}^{2} \cdot \mathrm{s} \cdot \mathrm{cmHg}\right)\end{array}$ & $\begin{array}{l}\text { Flexibility } \\
\text { (1-worst, } \\
5 \text { - best })\end{array}$ & $\begin{array}{c}\text { Flatness } \\
\text { (1-worst, } \\
\text { 5-best) }\end{array}$ \\
\hline \multicolumn{5}{|l|}{ PVDF } \\
\hline 206.7.2 & Kynar 721 & 0.11 & 3 & 5 \\
\hline 206.7.1 & Kynar 741 & 0.085 & 3 & 5 \\
\hline 206.4.1 & Kynar 761 & 0.07 & 3 & 4 \\
\hline 206.7.3 & Kynarflex 2801 & 0.039 & 3 & 5 \\
\hline 206.7.4 & Kynarflex 2851 & 0.084 & 3 & 5 \\
\hline \multicolumn{5}{|c|}{ Polyurethanes } \\
\hline 200.5 .2 & Estane 5714-F5P & 0.12 & 5 & 5 \\
\hline 206.5.3 & Estane 2714 & 0.12 & 5 & 5 \\
\hline 206.5.1 & Pellethane 2103-55D & 0.013 & 4 & 5 \\
\hline 206.8.1 & Pellethane 2103-80AEF & 0.19 & 5 & 5 \\
\hline 206.8 .2 & Pellethane 2103-90AEF & 0.15 & 5 & 5 \\
\hline
\end{tabular}

\section{Loading and Thickness}

The sorbent content and thickness of the sorbent layer are also important to the overall performance of the final protective fabric. We examined sorbent layers with sorbent contents between 0 and $63 \%$ (by weight). Table 16 shows some physical properties of sorbent layers with different carbon contents cast onto woven nylon, and Figure 12 shows the MVTR of fabrics containing 30 to $60 \mathrm{wt} \%$ carbon. Qualitatively, we noted that the durability is diminished above 50 wt $\%$ carbon, while lower content reduces the quantity of sorbent available and reduces water vapor transmission through the sorbent layer. Therefore, we concluded that $50 \%$ is a good choice for sorbent loading.

The sorbent layer thickness ( $\sim 5$ mils) was chosen to make the layer as thin as possible (to increase flexibility and reduce weight), while ensuring that the layer is consistent and smooth. The selected thickness and sorbent content result in a sorbent loading of $\sim 50 \mathrm{~g} / \mathrm{m}^{2}$. 
Table 16. Relationship Between Carbon Loading in Sorbent Matrix and Mechanical Properties

\begin{tabular}{||c|c|c|c|c|c||}
\hline Sample ID & Polymer & $\begin{array}{c}\text { Carbon } \\
\text { in Sorbent } \\
\text { Layer (wt\%) }\end{array}$ & $\begin{array}{c}\text { Nitrogen } \\
\text { Pressure-Normalized Flux } \\
\left(\mathbf{c m}^{3} \text { (STP)/cm²s·cmHg) }\right.\end{array}$ & $\begin{array}{c}\text { Flexibility } \\
\text { (1-worst, } \\
\text { 5-best) }\end{array}$ & $\begin{array}{c}\text { Flatness } \\
\text { (1-worst, } \\
\text { 5-best) }\end{array}$ \\
\hline 206.2 .1 & $\begin{array}{c}\text { PVDF } \\
\text { (Kynar 761) }\end{array}$ & 9 & 0.007 & 3 & 2 \\
\hline 206.3 .1 & $\begin{array}{c}\text { PVDF } \\
\text { (Kynar 761) }\end{array}$ & 23 & 0.008 & 3 & 3 \\
\hline 206.3 .2 & $\begin{array}{c}\text { PVDF } \\
\text { Kynar 761) }\end{array}$ & 33 & 0.022 & 3 & 4 \\
\hline 206.3 .3 & $\begin{array}{c}\text { PVDF } \\
\text { (Kynar 761) }\end{array}$ & 44 & 0.052 & 4 & 4 \\
\hline 206.4 .1 & $\begin{array}{c}\text { PVDF } \\
\text { (Kynar 761) }\end{array}$ & 50 & 0.07 & 4 & 4 \\
\hline 206.4 .2 & $\begin{array}{c}\text { PVDF } \\
\text { (Kynar 761) }\end{array}$ & 57 & 0.12 & 4 & 5 \\
\hline 206.4 .3 & $\begin{array}{c}\text { PVDF } \\
\text { (Kynar 761) }\end{array}$ & 63 & 0.18 & 4 & 5 \\
\hline 206.5 .2 & $\begin{array}{c}\text { Polyurethane } \\
\text { (Estane 5714-F5P) }\end{array}$ & 50 & 0.12 & 5 & 5 \\
\hline 206.5 .3 & $\begin{array}{c}\text { Polyurethane } \\
\text { (Estane 5714-F5P) }\end{array}$ & 60 & 0.027 & 5 & 5 \\
\hline \hline
\end{tabular}

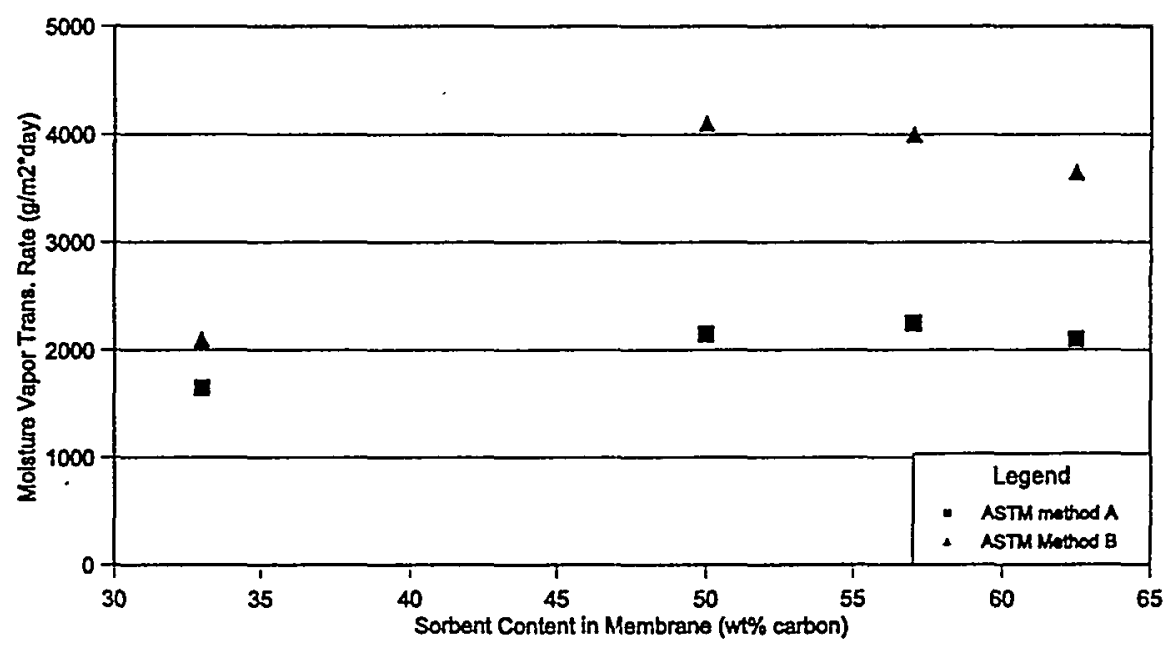

Figure 12. Effect of sorbent content on moisture vapor transmission rate (MVTR). 


\section{Final Sorbent Layer}

To choose between the two best sorbents (Calgon Carbon PCB-G and Zeochem 13x) and polymers (Pellethane 2103-AEF and Kynarflex 2851), we cast sorbent layers onto woven nylon support fabrics using the four possible combinations of sorbent and polymer: polyurethane/carbon, polyurethane/zeolite, PVDF/carbon, and PVDF/zeolite. These four fabrics were tested for MVTR and chemical permeation. Figure 13 shows that there was no significant difference between the four fabrics in terms of MVTR. Later experiments with various permselective layers showed the permselective layer to be most important to resisting chemical permeation, and that any of the sorbent layers could be used to prevent chemical permeation given an appropriate permselective layer. Although Scanning Electron Micrographs (SEMs) show that Pellethane has more surface defects than Kynar and is, therefore, more difficult to coat with a defect-free membrane layer (see Section 5.3.3), this disadvantage of polyurethane is more than overcome by its superior flexibility and durability.

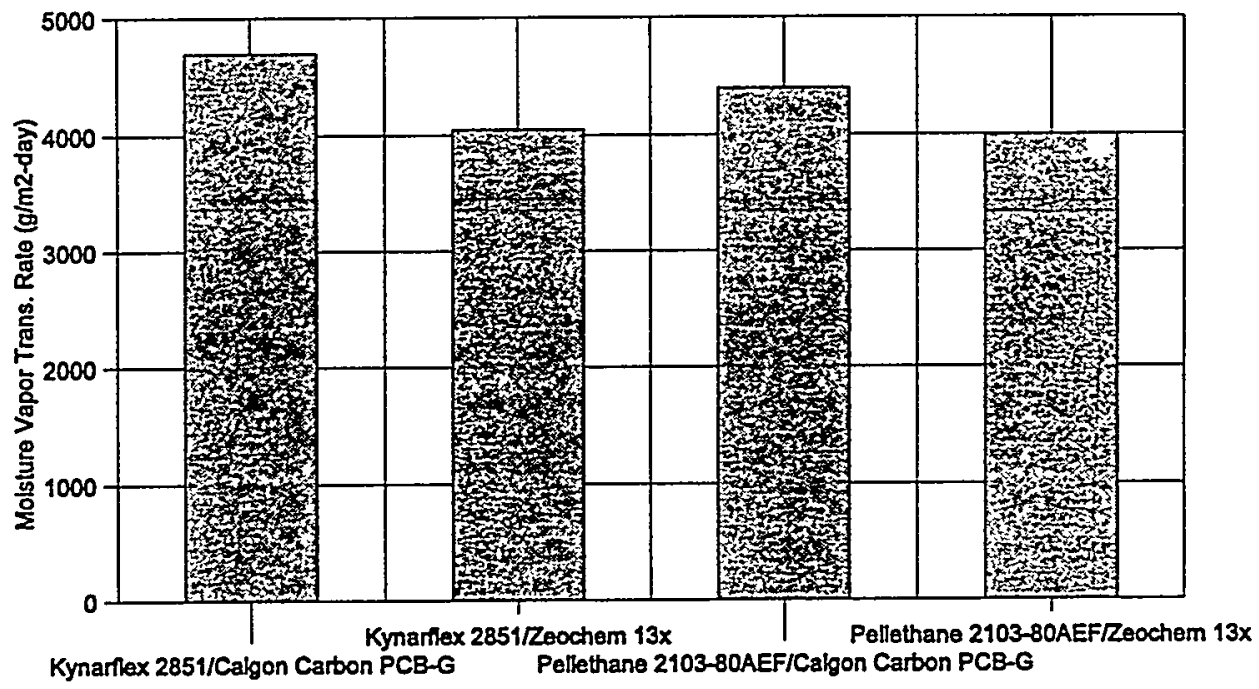

Figure 13. Moisture vapor transmission rate (MVTR) through the four short-listed fabric layers (ASTM Method A).

Because an adequate permselective layer can be coated on any of the four possible sorbent layers (PVDF/carbon, PVDF/zeolite, polyurethane/carbon, or polyurethane/zeolite), we used practical considerations to decide on the best combination. The black fabrics that result from using carbon made zeolite the best choice of absorbent, and the superior flexibility and durability of polyurethane determined our choice of polymer. Our final sorbent layer formulation was $50 \mathrm{wt} \%$ zeolite (Zeochem 13x) in polyurethane (Pellethane 2103-80AEF). 


\subsubsection{Permselective Layer}

Several polymers were evaluated for use as the permselective layer. The polymer selected, polyvinyl alcohol (PVA) (Airvol 425, Air Products, Calvert City, KY), was chosen for its combination of organic permeation resistance, chemical resistance, water vapor transmission, and ease of use. A thickness of $\sim 5-10 \mu \mathrm{m}$ was chosen; a thinner layer resulted in defects in the permselective layer, whereas a thicker layer reduced the rate of water transmission unacceptably. A variety of post-treatment methods were tested to improve the permselective polymer's resistance to permeation by organic compounds, including various chemical crosslinking methods and radiation crosslinking.

In evaluating the permselective layer for resistance to chemical permeation, we tested permeation of only dichloromethane. We used only one challenge chemical during these tests because our main goal was to optimize the fabric. We believe that the fabric optimized with respect to one chemical will be optimal for other chemicals, although the actual permeation rates will differ. In general, because PVA is a hydrophilic polymer (which is the reason for its high water vapor transmission rate), hydrophobic chemicals such as dichloromethane will have lower permeation rates than hydrophilic chemicals such as acetone. However, when chemicals are tested in the presence of water vapor we expect the hydrophobic/hydrophilic nature of the chemical to have little influence on permeation rate.

We began the permselective layer optimization process with polyvinyl alcohol (PVA), because this polymer had shown high water permeation rates and good resistance to chemical permeation in earlier projects. PVA is produced by hydrolysis of polyvinyl acetate:

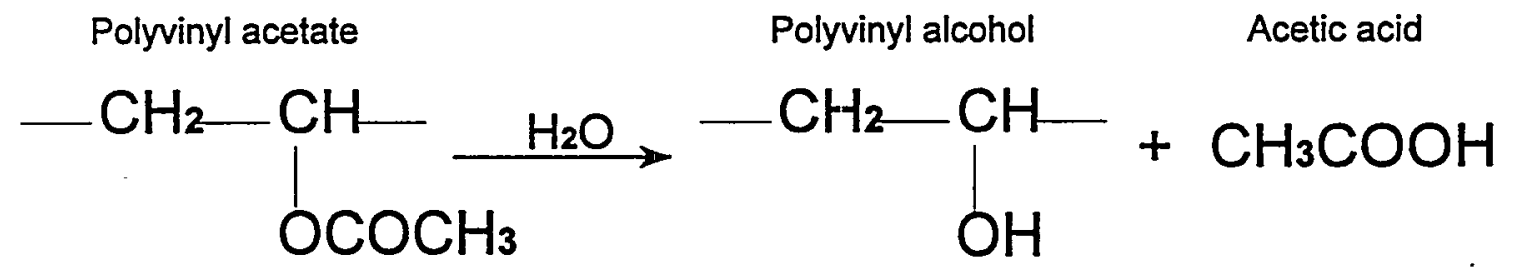

The percentage of acetate groups that have been converted to alcohol is referred to as the degree of hydrolysis. A description of PVA and the properties of different grades is given in Appendix C.

As described in Section 4.1, the permselective layer is coated onto the sorbent layer. The thickness of the permselective layer is controlled indirectly by adjusting the polymer concentration in the coating solution. A higher polymer concentration produces a more viscous solution, resulting in a thicker permselective layer. Our first step in the permselective layer optimization process was to determine the coating conditions required to produce a permselective layer that is thick enough to be defect-free, but not so thick as to impede water permeation unnecessarily. We evaluated coating solutions with concentrations of PVA in water from 3 to $8 \mathrm{wt} \%$, and also tested double coating as a means to increase thickness and reduce defects. 
During fabric optimization, SEMs of PVA-coated Kynar 761: carbon sorbent layers were prepared to determine the thickness of the permselective layers produced by different PVA solution concentrations. The SEM in Figure 14 shows a cross-section of a complete MTR fabric with the woven support fabric removed. A 140- $\mu \mathrm{m}$-thick Kynar 751 (PVDF) sorbent layer with imbedded carbon particles is visible. The dense PVA and silicone rubber layers are visible on top of the sorbent layer. The silicone rubber layer was added as a protective layer for the permselective PVA layer; later the idea of using the silicone rubber layer was discarded. ${ }^{1}$ Other examples of SEMs are given in Appendix D.

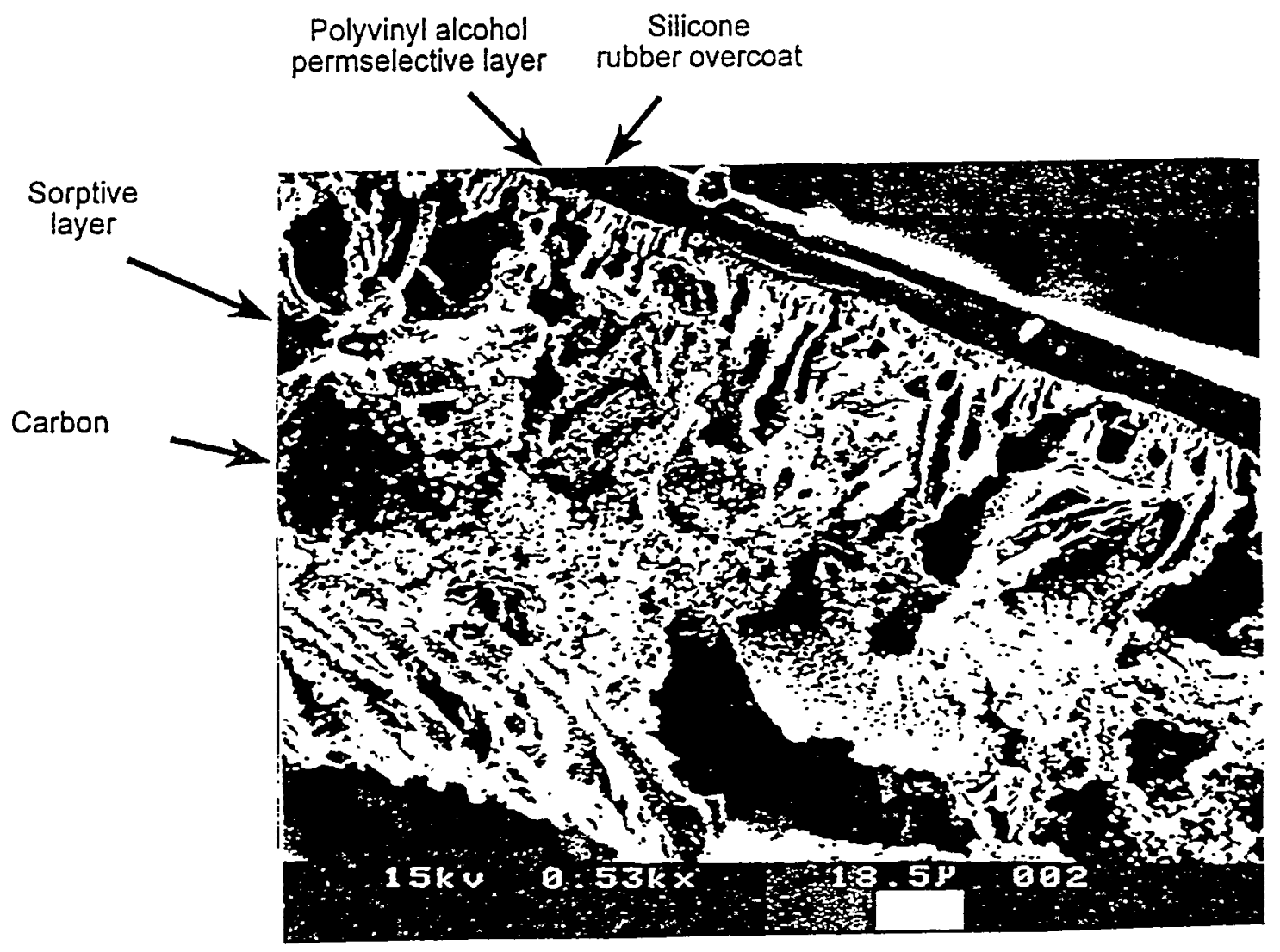

Figure 14. SEM of $8 \%$ polyvinyl alcohol (PVA) on Kynar 761 : carbon sorbent layer with $6 \%$ silicone rubber overcoat. Note carbon grains, PVA layer, and silicone rubber overcoat.

1 During the project, optimization of the permselective layer and sorbent layers was performed concurrently, so many of these tests were done with sorbent layers consisting of some other combination of sorbent and polymer than that finally chosen during the sorbent layer optimization. 
The relationship between coating procedure and PVA layer thickness is summarized in Table 17, along with results from chemical permeation tests. In all fabrics, the protective silicone rubber layer is about $3 \mu \mathrm{m}$ thick, but the PVA layer thickness depends on the coating solution concentration. Concentrations of $3 \%, 5 \%, 5 \%$ (double coat), and $8 \%$ PVA were evaluated. Concentrations above $8-10 \%$ cannot be used because, prior to coating, the solutions tend to gel spontaneously, causing defects in the resulting permselective layer. Although there is variability, Table 17 shows that thicker PVA layers result from more concentrated coating solutions, and that thicker PVA layers generally provide greater resistance to chemical permeation. We concluded that coating solutions containing 7 to $8 \mathrm{wt} \%$ PVA will result in fabrics with the best and most consistent protection against chemical vapor permeation. 
Table 17. Effect of Permselective Layer Type and Thickness on Dichloromethane Permeation

\begin{tabular}{|c|c|c|c|c|}
\hline Sorbent Layer & $\begin{array}{l}\text { PVA Coating } \\
\text { Solution } \\
\text { Concentration } \\
\text { (wt } \% \text { in water) }\end{array}$ & $\begin{array}{c}\text { PVA Layer } \\
\text { Thickness }(\mu \mathrm{m})\end{array}$ & $\begin{array}{c}\text { Dry } \\
\text { Normalized } \\
\text { Breakthrough } \\
\text { Time (min) } \\
\end{array}$ & $\begin{array}{c}\text { Dry Steady-State } \\
\text { Permeation Rate } \\
\text { (Dichloromethane) } \\
\left(\mu \mathrm{m} / \mathrm{cm}^{2} \cdot \min \right) \\
\end{array}$ \\
\hline \multirow[t]{5}{*}{$\begin{array}{l}50 \text { wt } \% \text { Kynar } \\
761 \text { (PVDF) } \\
50 \text { wt\% Calgon } \\
\text { Carbon PCB-G }\end{array}$} & $3 \%$ & Discontinuous & $\begin{array}{l}1.0 \\
1.1 \\
2.2 \\
0.8 \\
\end{array}$ & $\begin{array}{l}200 \\
313 \\
172 \\
270\end{array}$ \\
\hline & $2 \times 3 \%$ & & $\begin{array}{l}1.2 \\
9.2 \\
0.5 \\
0.5 \\
\end{array}$ & $\begin{array}{c}75 \\
40 \\
230 \\
0.1 \\
\end{array}$ \\
\hline & $5 \%$ & 2.5 & & \\
\hline & $2 \times 5 \%$ & 8 & $\begin{array}{c}5.0 \\
12.2 \\
4.6 \\
>360\end{array}$ & $\begin{array}{c}38 \\
60 \\
12.4 \\
0.01\end{array}$ \\
\hline & $8 \%$ & 7 & 33 & 5.5 \\
\hline \multirow{5}{*}{$\begin{array}{l}50 \text { wt } \% \\
\text { Pellethane } \\
2103-80 \text { AEF } 761 \\
\text { (Polyurethane) } \\
50 \text { wt\% Calgon } \\
\text { Carbon PCB-G }\end{array}$} & $3 \%$ & & 0.4 & 185 \\
\hline & $2 \times 3 \%$ & & $\begin{array}{l}1.0 \\
0.5 \\
\end{array}$ & $\begin{array}{l}340 \\
185 \\
\end{array}$ \\
\hline & $5 \%$ & & $\begin{array}{l}1.3 \\
1.2 \\
1.2\end{array}$ & $\begin{array}{l}5.2 \\
6.8 \\
1.0\end{array}$ \\
\hline & $6 \%$ & & $\begin{array}{l}1.3 \\
0.8 \\
2.0\end{array}$ & $\begin{array}{l}5.2 \\
6.8 \\
1.0 \\
\end{array}$ \\
\hline & $7 \%$ & & $\begin{array}{l}>1,000 \\
>1,000 \\
\end{array}$ & $\begin{array}{l}0.6 \\
0.1 \\
\end{array}$ \\
\hline
\end{tabular}

\section{Chemical Permeation in the Presence of Water Vapor}

In use, protective clothing will face chemical contaminants on the outside of the fabric and a humid atmosphere, caused by the wearer's perspiration, on the inside. To more accurately simulate these conditions, we humidified the nitrogen sweep gas on the permeate side of our dichloromethane challenge cell. 
PVA has a high water vapor permeation rate because it is swollen by water; organic compounds do not swell PVA and thus do not permeate. However, if water vapor is present to swell the PVA layer, organic chemicals may also permeate simultaneously with the water. To determine the effect of water vapor on the barrier properties of the PVA layer to organic vapors, we tested samples of fabrics both with and without water vapor present. (These samples include PVA layers crosslinked by a variety of methods as described below.) The results are summarized in Table 18. Samples were equilibrated first with dry nitrogen and then re-equilibrated with humidified nitrogen on the permeate side to determine permeation rates with and without water vapor present.

Table 18. Effect of Water Vapor on Dichloromethane Permeation

\begin{tabular}{|l|c|c|}
\hline \multicolumn{1}{|c|}{ Sample ID } & $\begin{array}{c}\text { Dry Steady-State } \\
\text { Permeation Rate } \\
\left(\mu \mathrm{g} / \mathrm{cm}^{2} \cdot \mathbf{m i n}\right)\end{array}$ & $\begin{array}{c}\text { Humid Steady- } \\
\text { State Permeation } \\
\text { Rate }\left(\mu \mathrm{g} / \mathrm{cm}^{2} \cdot \mathbf{m i n}\right)\end{array}$ \\
\hline $206.18 .4 .1 \mathrm{LG}$ & 0.095 & $>10$ \\
\hline $206.18 .4 .1 \mathrm{LG} \mathrm{\# 2}$ & 0.084 & 2.3 \\
\hline $206.13 .1 .2 \mathrm{H}$ & 0.095 & $>10$ \\
\hline $40-30.1$ & 1.36 & $>10$ \\
\hline
\end{tabular}

The permeation results show that water vapor has a negative effect on the barrier properties of PVA. Even in the best sample (206.18.4.1LG \#2), the humid steady state permeation rate was 20 times higher than under the dry conditions. In all other samples, the permeation rate was too high to be measured on our chart recorder.

Three options to improve the organic-permeation barrier properties of the fabric in the presence of water vapor were evaluated: 1) using an alternative water-permeable polymer as a barrier layer, 2) using a more hydrolyzed grade of PVA that can be more completely crosslinked and will swell less, and 3) using a different crosslinking method that results in a more stable PVA layer.

The first approach used to circumvent the problem of PVA's reduced organic permeation resistance in the presence of water vapor was to use an alternative permselective polymer. One of the most promising polymers was Eval, an ethylene/vinyl alcohol copolymer (Evalca, Lisle IL 60532). In addition to three different grades of polymer (L101, F101 G156), we received three prepared Eval films ready to test for dichloromethane resistance. All three Eval films had good resistance to dichloromethane under both wet and dry conditions. However, the MVTRs of the films were lower than PVA layers (and at least $80 \%$ lower than Tyvek, our standard for comparison) because the films were four to five times thicker than the PVA permselective layers. We concluded that thinner Eval films might be ideal protective clothing permselective layers, if they could be prepared by solution coating. 
We prepared fabric samples using an Eval-based coating solution from the Mica Corporation (Stratford CT, 06947) to prepare the permselective layer. The Mica solvent is a water/isopropyl alcohol mixture with two additional proprietary ingredients that give the solution good coating properties. As received, the Eval concentration in the solution was $10 \%$, and the initial viscosity was 310 centipoise (cp). We coated this solution (designated Eval-1) onto both PVDF/paper and. polyurethane: carbon/nylon, and tested the resulting fabrics for both MVTR and dichloromethane permeation rates. We then diluted the initial Mica solution with water and isopropyl alcohol to make lower viscosity coating solutions (Eval-2 and Eval-3), which resulted in thinner permselective layers. These two solutions were coated onto the same microporous layers. Eval-3 was also coated onto a PVDF:carbon layer.

All of the Eval-based fabrics (except for 206.13.2.8) have good resistance to dichloromethane under humid conditions. Dichloromethane permeation breakthrough times are much faster than the 60 minute target, and steady-state permeation rates, although still higher than the target $0.1 \mu \mathrm{g} / \mathrm{cm}^{2} \cdot \mathrm{min}$, are as much as 100 times lower than for our standard PVA-based fabrics tested under similar conditions. However, the MTVRs of all of the fabrics are at least $35 \%$ lower than Tyvek, our standard fabric for comparison. Based on these data, we concluded that Eval is too impermeable to water vapor to use as a permselective layer.

With the goal of achieving both good organic vapor resistance and high MVTR, we made permselective fabrics using a blend of Eval and PVA. We combined the Eval solution supplied by Mica with our standard PVA coating solution, heated and stirred the mixture, and diluted it with npropanol and distilled water to obtain a completely clear, one-phase solution. However, even though ethylene vinyl alcohol and polyvinyl alcohol are chemically similar, they are soluble only in specific solvents; we could not obtain a one-phase solution containing both polymers. Using a two-phase mixture comprising $2.2 \%$ Eval, $2.2 \%$ PVA in a $52 / 48$ water $/ \mathrm{n}$-propanol mixture (viscosity $35 \mathrm{cp}$, low for a typical coating solution), we coated four different sorbent fabrics. Our threshold nitrogen permeation rate for a defect-free permselective layer is $<1.0 \times 10^{-7} \mathrm{~cm}^{3} / \mathrm{cm}^{2} \cdot \mathrm{s}^{\cdot} \mathrm{cmHg}$. The best result obtained with the Eval/PVA-coated fabric was almost two orders of magnitude higher than our threshold. We concluded that these permselective fabrics will not provide adequate organic resistance.

We also evaluated samples of Hydrin and Parel (Zeon Chemicals, Inc., Rolling Meadows, II), two other alternative permselective polymers. Hydrin is an epichlorohydrin-based polymer, and Parel is a copolymer of propylene oxide and allyl glycidyl ether; two grades of Parel were received. Solubility tests with $2 \%$ of each polymer added to toluene showed that only the Hydrin dissolved completely. A small sample of membrane was prepared from this solution and tested for gas permeation properties. The nitrogen flux of a defect-free stamp was $6.5 \times 10^{-6} \mathrm{~cm}^{3} / \mathrm{cm}^{2} \cdot \mathrm{s} \cdot \mathrm{cmHg}$, which is two orders of magnitude higher than that of defect-free PVA. However, mixed-gas permeation measurements showed the membrane to be defect-free, thus the permeation rate was considered too high for Hydrin to be used as a chemical barrier layer.

Our second approach to the water vapor issue was to evaluate alternative grades of PVA. The polymer is available in a number of grades depending on the degree of hydrolysis and the 
molecular weight of the polymer chains. Table 19 shows Airvol PVA grades (available from Air Products and Chemicals) and physical properties (see also Appendix C). Figure 15 shows the effect of molecular weight and degree of hydrolysis on the physical and chemical properties of PVA. Desired properties of the PVA layer include strength, water resistance, solvent resistance, and adhesive strength - properties that are enhanced by high molecular weight and a high degree of hydrolysis. On the other hand, to be coatable, the PVA must be soluble in water and the resulting PVA layer must be flexible; these properties are enhanced by low molecular weight and low degree of hydrolysis.

Table 19. Airvol Polyvinyl Alcohol (PVA) Grades

\begin{tabular}{|c|c|c|c|c|}
\hline \multirow{2}{*}{$\begin{array}{c}\text { Grade } \\
\text { Super hydrolyzed }\end{array}$} & \multicolumn{2}{|c|}{$\begin{array}{c}\text { Degree of } \\
\text { Hydrolysis (\%) }\end{array}$} & \multirow{2}{*}{$\begin{array}{c}\begin{array}{c}\text { Viscosity } \\
\text { (centipoise) }\end{array} \\
28-32 \\
62-72\end{array}$} & \multirow{2}{*}{$\begin{array}{c}\begin{array}{c}\text { Estimated } \\
\text { Average } \mathbf{M W} \\
\text { (number } \\
\text { average) }\end{array} \\
65,000 \\
100,000 \\
\end{array}$} \\
\hline & $\begin{array}{l}\text { Airvol } 125 \\
\text { Airvol } 165\end{array}$ & $\begin{array}{l}99.3+ \\
99.3+\end{array}$ & & \\
\hline Fully hydrolyzed & $\begin{array}{l}\text { Airvol } 103 \\
\text { Airvol } 107 \\
\text { Airvol } 321 \\
\text { Airvol } 325 \\
\text { Airvol } 350\end{array}$ & $\begin{array}{l}98.0-98.8 \\
98.0-98.8 \\
98.0-98.8 \\
98.0-98.8 \\
98.0-98.8\end{array}$ & $\begin{array}{c}3.5-4.5 \\
5.5-6.6 \\
16.5-20.5 \\
28.5-32.5 \\
62-72\end{array}$ & $\begin{array}{c}12,000 \\
25,000 \\
40,000 \\
65,000 \\
100,000 \\
\end{array}$ \\
\hline Intermediately hydrolyzed & $\begin{array}{c}\text { Airvol WS-42 } \\
\text { Airvol } 425\end{array}$ & $\begin{array}{l}96.5-97.5 \\
95.5-96.5 \\
\end{array}$ & $\begin{array}{l}14-17 \\
27-31\end{array}$ & $\begin{array}{l}70,000 \\
60,000\end{array}$ \\
\hline Partially hydrolyzed & $\begin{array}{l}\text { Airvol } 203 \\
\text { Airvol } 205 \\
\text { Airvol } 523 \\
\text { Airvol } 540 \\
\end{array}$ & $\begin{array}{l}87.0-89.0 \\
87.0-89.0 \\
87.0-39.0 \\
87.0-89.0 \\
\end{array}$ & $\begin{array}{l}3.4-4.5 \\
5.2-6.2 \\
23-27 \\
45-55 \\
\end{array}$ & $\begin{array}{l}12,000 \\
22,000 \\
50,000 \\
75,000 \\
\end{array}$ \\
\hline
\end{tabular}




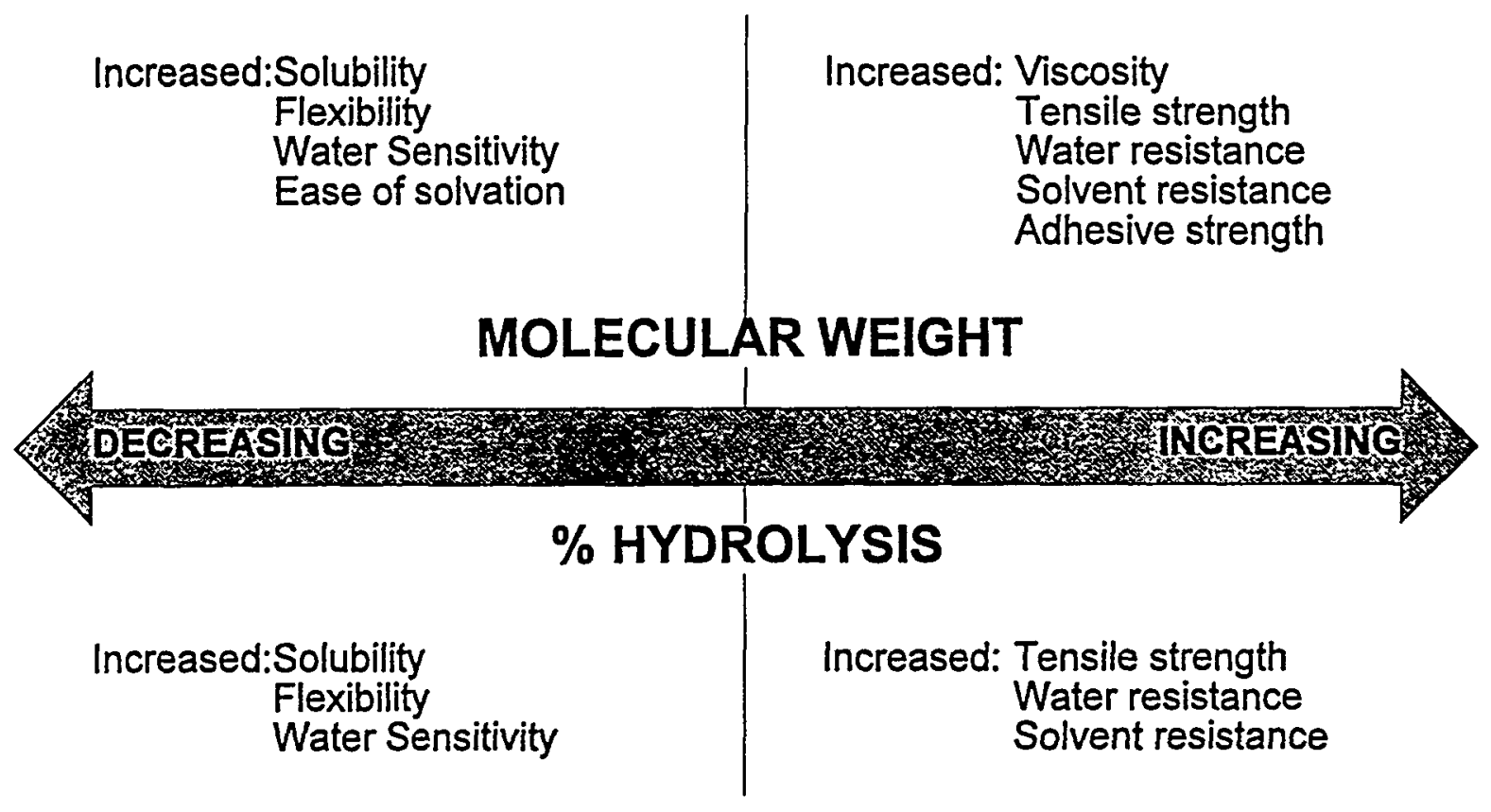

Figure 15. Effect of molecular weight and degree of hydrolysis on physical and chemical properties.

Highly hydrolyzed PVAs (>99\%) tend to gel and form particles, causing noticeable defects in the PVA layer. However, the more hydrolyzed grades can be more fully crosslinked, which would make them more chemically resistant than the partially hydrolyzed grades. Thus, the ideal grade of PVA for our purposes is the most hydrolyzed grade that forms a stable solution without gelling. We prepared PVA solutions from each of the four grades: super hydrolyzed (Scientific Polymer Products, Inc; PVA-002), fully hydrolyzed (Airvol 250), intermediate hydrolyzed (Airvol 425), and partially hydrolyzed (Airvol 540). Both super and fully hydrolyzed grades resulted in some gelling of the solution, so the intermediately hydrolyzed grade, Airvol 425 was chosen for the polymer used in the permselective layer.

The third approach to maintaining chemical permeation resistance in the presence of water vapor was to enhance the stability of PVA by crosslinking it. In crosslinking, individual polymer chains are linked to each other by reaction leading to a covalent bond. This reaction can involve another compound (a crosslinking agent), or may involve only side groups of the polymer chain.

Two basic crosslinking methods were used: electron beam irradiation and chemical crosslinking. The results are illustrated in Figure 16. In electron beam irradiation, electrons colliding with PVA molecules break bonds in these molecules. The open bonds can then form bonds with other PVA molecule, resulting in crosslinking. The higher the energy used during irradiation, the greater the degree of crosslinking. Chemical crosslinking is achieved by adding a crosslinking agent with multiple sites that can react with PVA molecules. Reaction of this compound with more than one PVA molecule results in crosslinking. The degree of crosslinking depends on the amount of crosslinking agent added, the temperature, and the presence of a catalyst. 
<smiles>CCOCCOCCOCCOC</smiles><smiles></smiles><smiles>CCC(O)CC(O)CC(O)CC(O)CC</smiles>

\section{Not Crosslinked}

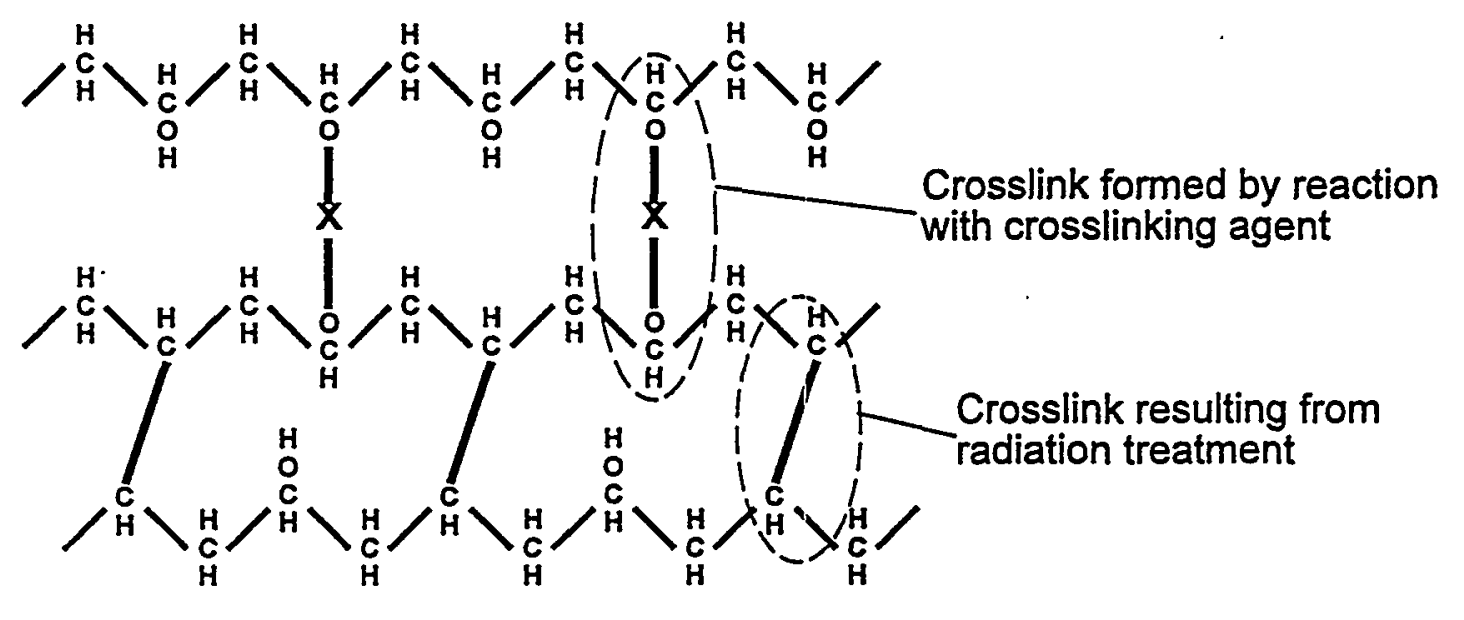

Crosslinked

Figure 16. Schematic showing crosslinking of polyvinyl alcohol (PVA) by chemical and radiation treatments.

Our first experiments compared electron-beam irradiation with chemical crosslinking. The PVA was cast onto a support consisting of a microporous PVDF film containing no sorbent cast onto a nonwoven paper. Because this support is very consistent, differences between PVA layers are more apparent than if the PVA were coated onto our woven nylon support. Electron-beamcrosslinked samples were irradiated for us by E-Beam Services (Cranbury, NJ) at several power 
settings. Chemical crosslinking was achieved using a glutaric aldehyde crosslinking agent ( $20 \%$ by weight in PVA) and heating to approximately $120^{\circ} \mathrm{C}$. A hydrochloric acid catalyst was used to lower the $\mathrm{pH}$ of the PVA solution to between 5 and 6 , and increase the rate of the crosslinking reaction.

Table 20 shows the MVTRs and dichloromethane permeation rates of samples made by the two crosslinking methods. The data show that all of the crosslinking conditions reduce the dichloromethane permeation rate substantially. Crosslinking by electron beam irradiation provided good permeation resistance, but the chemical method resulted in the greatest permeation resistance. Electron beam irradiation resulted in no decrease in MVTR compared with a non-crosslinked sample, whereas the chemical method reduced the MVTR by as much as one third. We have chosen to use the chemical crosslinking method (with $\mathrm{HCl}$ catalyst) to make our selective layer. This decision was made on the basis that this layer gave the best resistance to chemical permeation and had an adequate MVTR, and that the crosslinking can be done at MTR.

Table 20. Characteristics of Polyvinyl Alcohol (PVA) Layers Crosslinked by Various Methods

\begin{tabular}{||l|c|c||}
\hline Crosslinking Method: & $\begin{array}{c}\text { MVTR } \\
\left(\mathbf{g} / \mathbf{m}^{2} \cdot \mathbf{2 4 h}\right)\end{array}$ & $\begin{array}{c}\text { Dichloromethane } \\
\text { Permeation Rate } \\
\left(\mu \mathbf{g} / \mathbf{c m}^{2} \cdot \mathbf{m i n}\right)\end{array}$ \\
\hline None & 2,500 & 4.9 \\
\hline \begin{tabular}{|l} 
Electron-beam irradiation \\
$3 \mathrm{mrad}$
\end{tabular} & 2,650 & 1.29 \\
$9 \mathrm{mrad}$ & 2,500 & 0.47 \\
$15 \mathrm{mrad}$ & 2,550 & 0.43 \\
\hline Chemical & & \\
Glutaraldehyde & 1,800 & 0.58 \\
Glutaraldehyde $+\mathrm{HCl}$ & 1,600 & 0.21 \\
\hline
\end{tabular}

We also evaluated a variety of crosslinking agents to find the agent that is most effective and is easiest and safest to use. Because of the small amounts of material used, cost was not an issue in the choice. The data are summarized in Table 21 . All of the chemically crosslinked permselective layers had similar chemical permeation and water vapor transmission properties, however, Cymel 385 , a melamine-formaldehyde resin, had the best combination of efficacy, safety, and ease of use. 
Table 21. Properties of Membranes Made with Different Crosslinking Agents Compared with Safety and Ease of Use of Agent

\begin{tabular}{|c|c|c|}
\hline Crosslinker & $\begin{array}{l}\text { Water Stability and } \\
\text { Chemical Permeation } \\
\text { Resistance of Membrane }\end{array}$ & $\begin{array}{l}\text { Safety and } \\
\text { Ease of Use }\end{array}$ \\
\hline Glyoxal & poor & Relatively safe (irritant) \\
\hline Quilon & good & $\begin{array}{l}\text { Unsafe (flammable, corrosive, suspected } \\
\text { mutagen) }\end{array}$ \\
\hline Gantrez AN & fair & $\begin{array}{l}\text { Unsafe (toxic, mutagen, irritant, suspected } \\
\text { carcinogen) }\end{array}$ \\
\hline Tyzor AA & fair & Unsafe (flammable, toxic, eye irritant) \\
\hline Glutaraldehyde & good & $\begin{array}{l}\text { Unsafe (highly toxic, corrosive, absorbs } \\
\text { through skin) }\end{array}$ \\
\hline Cymel 385 & good & Relatively safe (irritant) \\
\hline Cymel 1172 & good & Relatively safe (irritant) \\
\hline
\end{tabular}

\subsubsection{Protective Layer}

The purpose of the surface protective layer is to improve the durability of the fabric while maintaining its flexibility and protection. Because the permselective layer is very thin, it is fragile and easily damaged. Originally we proposed to use a layer of silicone rubber to protect the permselective layer. However, our commercial contacts indicated that a silicone rubber layer would not provide sufficient protection from normal workplace hazards such as abrasion from rough surfaces and punctures caused by sharp edges. An alternative approach to protecting the permselective layer is to bond two identical sheets of the MTR composite fabric face to face as shown in Figure 10. For this approach to be successful, a suitable lamination technique was needed. Two methods were evaluated: directly bonding the PVA coats of each fabric and using an adhesive (PVA or some other adhesive). Of the two lamination techniques, the first-direct bonding-is preferred because it creates no additional material costs and adds no problems in terms of chemical resistance or water vapor transmission rate of the adhesive. To form the laminated fabric successfully, two criteria had to be met:

1) the PVA layer on at least one of the two layers, and preferably both, must be consistently defect free, and

2) the lamination technique must not affect the water vapor transmission rate, produce defects in the PVA layer, or cause a loss in flexibility. 
Three approaches to direct bonding were used:

1) Bond the fabrics by wetting the PVA surfaces and heating/pressing the two fabrics together. (PVA is often used as an adhesive; wetting the PVA surfaces takes advantage of these adhesive properties).

2) Bond the fabrics by wetting the PVA surfaces with water containing the crosslinking agent and catalyst and heating/pressing the two fabrics together. This may improve the bonding by crosslinking between the two surfaces.

3) Bond the fabrics by wetting the PVA surfaces with a $2 \%$ PVA solution containing the crosslinking agent and catalyst and heating/pressing the two fabrics together.

The properties of the fabrics produced by these laminating methods are summarized in Table 22. The MVTRs of the laminated fabrics were still high (more than twice that of Tyvek), but only two showed improvements in dichloromethane permeation resistance over the single layer of fabric. Breakthrough times of the laminated fabrics were, in general, longer than the single layers, but this is because the laminate is a thicker barrier and the dichloromethane takes longer to diffuse through the combined layers. The higher final permeation rates for the laminates suggest that they have more defects than the single layers; we concluded that direct lamination damages the permselective PVA layer. 
Table 22. Specification and Properties of Fabrics Laminated by Direct Bonding

\begin{tabular}{|c|c|c|c|c|}
\hline \multirow[b]{2}{*}{ Fabric ID No. } & \multirow[b]{2}{*}{$\begin{array}{l}\text { Lamination } \\
\text { Method }\end{array}$} & \multirow{2}{*}{$\begin{array}{c}\text { Average } \\
\text { MVTR } \\
\left(\mathrm{g} / \mathrm{m}^{2} \cdot 24 \mathrm{~h}\right)\end{array}$} & \multicolumn{2}{|c|}{ Dichloromethane Permeation } \\
\hline & & & $\begin{array}{l}\text { Breakthrough } \\
\text { Time (min) }\end{array}$ & $\begin{array}{l}\text { Permeation Rate } \\
\left(\mu \mathrm{g} / \mathrm{cm}^{2} \cdot \mathrm{min}\right)\end{array}$ \\
\hline 206.12.4.1LW & Water & 6,200 & $\begin{array}{l}\text { immediate } \\
\text { immediate }\end{array}$ & $\begin{array}{l}\text { high } \\
\text { high }\end{array}$ \\
\hline 206.16.1.1LW & Water & 7,500 & $\begin{array}{l}1 \\
1\end{array}$ & $\begin{array}{l}\text { high } \\
\text { high }\end{array}$ \\
\hline 206.13.1.1LW & Water & 9,000 & $\begin{array}{l}2 \\
4\end{array}$ & $\begin{array}{l}\text { high } \\
\text { high }\end{array}$ \\
\hline 206.16.1.1LG & $\begin{array}{l}\text { Water containing crosslinking } \\
\text { agent and catalyst }\end{array}$ & 7,500 & $\begin{array}{r}62 \\
3\end{array}$ & $\begin{array}{c}0.2 \\
3\end{array}$ \\
\hline 206.13.1.1LG & $\begin{array}{l}\text { Water containing crosslinking } \\
\text { agent and catalyst }\end{array}$ & 8,300 & $\begin{array}{r}10 \\
>1,040 \\
15\end{array}$ & $\begin{array}{c}\text { high } \\
0.07 \\
2\end{array}$ \\
\hline 206.16.1.1L2P & $\begin{array}{l}\text { 2\% PVA solution containing } \\
\text { crosslinking agent and catalyst }\end{array}$ & 8,000 & $\begin{array}{l}2 \\
8\end{array}$ & $\begin{array}{l}\text { high } \\
\text { high }\end{array}$ \\
\hline 206.13.1.1L2P & $\begin{array}{l}\text { 2\% PVA solution containing } \\
\text { crosslinking agent and catalyst }\end{array}$ & 7,800 & $\begin{array}{r}40 \\
4 \\
8\end{array}$ & $\begin{array}{c}6 \\
\text { high } \\
3\end{array}$ \\
\hline
\end{tabular}

To evaluate bonding by adhesives, we obtained a number of adhesive samples. To prepare the laminate, a piece of fabric was coated with adhesive and allowed to dry; an identically sized piece was then rolled out over it. The laminated fabric was then tested for both moisture vapor transmission rate and for dichloromethane permeation. The adhesive layer reduced the MVTR significantly, such that the none of the adhesives tested can be considered for laminating our fabrics.

\section{COMMERCIAL-SCALE FABRIC PRODUCTION}

\subsection{Objective}

The objective of this task was to scale up fabric production from the formulation developed with our laboratory-scale equipment, to our large, cormmercial scale ( $1 \mathrm{~m}$ wide) equipment. This large-scale casting and coating equipment is essentially the same as that described previously in section 4.1, except that it is wider. Problems that can be encountered during scaleup typically have to do with difficulties in handling the wider fabric, for example, wrinkling and curling of the edges. 


\subsection{Summary of Results of Scaleup}

The final fabric formulation is shown in Table 23. One 90-m-long roll of the material shown in Figure 10 (MTR-2) was prepared, plus one 40-m-long roll using the nonwoven material for the inner layer (MTR-1).

Table 23. Summary of Protective Fabric Materials and Production Process

\begin{tabular}{|c|c|c|}
\hline Layer & $\begin{array}{l}\text { Formation } \\
\text { Process }\end{array}$ & Material Specifications \\
\hline Support fabric & - & $\begin{array}{l}\text { MTR-2: Ripstop nylon (HLC Dover style } 7020 \text { \#1) } \\
\text { MTR-1: Hytril/nonwoven laminate }\end{array}$ \\
\hline $\begin{array}{l}\text { Sorbent layer } \\
\text { (wet) }\end{array}$ & Solution casting & $\begin{array}{l}\text { Casting solution: } \\
17 \mathrm{wt} \% \text { Pellethane } 2103-80 \mathrm{AEF} \\
17 \mathrm{wt} \% \text { zeolite } 13 \times(1-3 \mathrm{~mm} \text { particle size) } \\
\text { Solvent: dimethyl acetamide (DMAc) }\end{array}$ \\
\hline Sorbent layer & Drying & Hot air drying \\
\hline $\begin{array}{l}\text { Permselective } \\
\text { layer/Lamination }\end{array}$ & Dip coating & $\begin{array}{l}\text { Coating/laminating solution: } \\
8 \mathrm{wt} \% \text { polyvinyl alcohol (Airvol } 425 \text { ) } \\
1.6 \% \text { Cymel } 385 \\
\text { Solvent: water }\end{array}$ \\
\hline
\end{tabular}

Evaluations of the fabric performed by outside laboratories included chemical permeation, MVTR, and physical properties. The detailed reports are attached in Appendix E. The results showed that the fabrics met the water vapor transmission goal, and that the chemical permeation resistance was adequate, but not as high as hoped. Table 24 summarizes our test results, and includes comparisons with our project goals and with currently available protective clothing. For comparison, see Appendix B which is a table reproduced from Lab Safety Supply's catalog, showing the chemical permeation properties of 11 different fabrics toward a variety of hazardous chemicals. Whether our fabric properties are good enough for a commercially viable suit depends upon the economics.

Details of the scaleup process to commercial-scale fabric production are discussed in the following section. 
Table 24. Summary of Results of Laboratory Protective Fabric Tests (see Appendix E for details)

\begin{tabular}{|c|c|c|c|c|}
\hline Test/Fabric & Test I & Results & & als \\
\hline Chemical Permeation Tests & $\begin{array}{l}\text { Normalized } \\
\text { breakthrough } \\
\text { time (min) }\end{array}$ & $\begin{array}{l}\text { Steady-state } \\
\text { permeation rate } \\
\left(\mu \mathrm{g} / \mathrm{cm}^{2} \cdot \mathrm{min}\right)\end{array}$ & $\begin{array}{l}\text { Normalized } \\
\text { breakthrough } \\
\text { time (min) }\end{array}$ & $\begin{array}{l}\text { Steady-state } \\
\text { permeation rate } \\
\left(\mu \mathrm{g} / \mathrm{cm}^{2} \cdot \mathrm{min}\right)\end{array}$ \\
\hline MTR-1 (woven/nonwoven) & 1 & 441 & 300 & 30 \\
\hline MTR-2 (woven/woven) & 1 & 164 & & \\
\hline Saranex-coated Tyvek & 4 & 119 & & \\
\hline Water Vapor Transmission & $\begin{array}{l}\text { MVTR - standard } \\
\left(\mathrm{g} / \mathrm{m}^{2} \cdot \text { day }\right)\end{array}$ & $\begin{array}{c}\text { MVTR - inverted } \\
\left(\mathrm{g} / \mathrm{m}^{2} \cdot \text { day }\right)\end{array}$ & $\begin{array}{r}\mathrm{M} \\
(\mathrm{g} / \mathrm{m}\end{array}$ & $\begin{array}{l}\text { TR } \\
\text { day) }\end{array}$ \\
\hline MTR-1 & 816 & 1,165 & $800-$ &, 000 \\
\hline MTR-2 & 864 & 1,365 & & \\
\hline Physical Properties & Thickness (mils) & Weight $\left(o z / y d^{2}\right)$ & Thickness (mils) & Weight (oz/sq yd) \\
\hline MTR-1 & 10 & 5.7 & & \\
\hline MTR-2 & 8 & 6.1 & & \\
\hline Saranex-coated Tyvek & 10 & 3.6 & & \\
\hline Hydrostatic Resistance & $\begin{array}{c}\text { (before abrasion) } \\
\text { (psi) }\end{array}$ & $\begin{array}{c}\text { (after abrasion) } \\
\text { (psi) }\end{array}$ & $\begin{array}{c}\text { (before abrasion) } \\
\text { (psi) }\end{array}$ & $\begin{array}{c}\text { (after abrasion) } \\
\text { (psi) }\end{array}$ \\
\hline MTR-1 & 85 & 83 & & \\
\hline MTR-2 & 112 & 109 & & \\
\hline Grab Strength & $M(l b)$ & $\mathrm{XN}(\mathrm{lb})$ & $M(l b)$ & $\mathrm{XM}(\mathrm{lb})$ \\
\hline MTR-1 & 108 & 79 & & \\
\hline MTR-2 & 119 & 11.2 & & \\
\hline Flex Durability & $\mathrm{M}$ & $\mathrm{XM}$ & $\mathbf{M}$ & $\mathrm{XM}$ \\
\hline & (\# of pinholes after & (\# of pinholes after & (\# of pinholes after & (\# of pinholes after \\
\hline & & 2/00 ilex cycles) & & \\
\hline MTR-1 & 4 & 2 & & \\
\hline MTR-2 & 1 & 1 & & \\
\hline Tear Strength & $M($ gram $)$ & $\mathrm{XM}$ (gram) & $M$ (gram) & $\mathrm{XM}$ (gram) \\
\hline MTR-1 & 1,370 & 1,843 & & \\
\hline MTR-2 & 973 & 2,304 & & \\
\hline
\end{tabular}




\subsection{Details of Scaleup Process}

\section{Casting}

Difficulties encountered in scaling up the casting procedure to the wide machine included improper tension and wrinkling of the fabric; bleed-through of the polymer solution through the support fabric; and machine stoppages due to thick fabric edges, polymer bleed-through, and high solution viscosity.

To maintain even tension and prevent wrinkles, we installed spreader rollers on the feed roll and take-up rolls. These rollers have a spiral groove that maintains edge-to-edge tension, and successfully eliminated fabric wrinkling problems from the casting procedure.

The choice of Dover ripstop nylon as the support fabric was based partly on its weight and sheerness. A potential undesirable result of the fabric's sheerness is bleed-through of the polymer solution during casting. If the sorbent-layer polymer solution soaks through the support fabric instead of remaining on the top surface, stoppages in the casting process may result because of a buildup of friction underneath the moving support fabric. Bleed-through causes unevenness and streaks in the cast sorbent layer, and deposits large amounts of polymer debris on the back side of the fabric. This debris becomes embedded into the surface of the sorbent layer during take-up. Both the streaking and polymer debris produce defects in the permselective layer, and are unacceptable in a run intended for suit manufacture.

Bleed-through can be reduced by increasing the viscosity of the casting solution. However, solutions that are too viscous tend to produce dense, less water-permeable sorbent layers. There are also limits to the amount of polyurethane that can be dissolved into our casting solvent, dimethyl acetamide (DMAc). To determine the optimum casting solution viscosity, we made sorbent fabrics with casting solutions of different viscosities. Table 25 shows the solution viscosities and concentrations used to cast the three sorbent fabrics. The nitrogen permeation rates of the sorbent layers and MVTRs of the complete fabrics, which are indications of the porosity of the sorbent layer, are also included. 
Table 25. Effect of Casting Solution Concentrations and Viscosities on Nitrogen Permeation Flux of Sorbent Layer and MVTR of Complete Fabric

\begin{tabular}{||l|c|c|c||}
\hline $\begin{array}{c}|c| \\
\text { Casting } \\
\text { Solution } \\
\text { Formulation }\end{array}$ & $\begin{array}{c}\text { Casting Solution } \\
\text { Viscosity } \\
\text { (centipoise) }\end{array}$ & $\begin{array}{c}\text { Nitrogen } \\
\text { Permeation Flux } \\
\left(\mathbf{1 0}^{-2} \mathbf{c m}^{3} / \mathbf{c m}^{2} \cdot \mathbf{s} \cdot \mathbf{c m H g} \mathbf{H}\right)\end{array}$ & $\begin{array}{c}\text { MVTR of PVA- } \\
\text { Coated Fabric } \\
\left(\mathbf{g} / \mathbf{m}^{2} \cdot \mathbf{2 4 h}\right)\end{array}$ \\
\hline $\begin{array}{l}14 \% \text { Pellethane, } \\
14 \% \text { zeolite, in DMAc }\end{array}$ & 8,200 & 9.6 & 6,200 \\
\hline $\begin{array}{l}15 \% \text { Pellethane, } \\
15 \% \text { zeolite, in DMAc }\end{array}$ & 13,400 & 5.0 & 5,000 \\
\hline $\begin{array}{l}16 \% \text { Pellethane } \\
16 \% \text { zeolite, in DMAc }\end{array}$ & 22,000 & 3.8 & 4,600 \\
\hline
\end{tabular}

These results show that casting solutions of higher viscosity produce denser, less permeable sorbent layers and permselective fabrics with lower MVTRs. All of the casting solutions bled through the support fabric during casting: the $14 \%$ Pellethane solution bled through the nylon the most, while the $15 \%$ and $16 \%$ bled through relatively little. We believe that the amount of bleedthrough by the $15 \%$ and $16 \%$ Pellethane/zeolite solutions can be minimized by changes in casting technique on the 1-meter wide machine. Based on these results, the sorbent layer will be cast from a solution of target viscosity 15,000 to 20,000 centipoise, by adjusting polymer concentration in the $15-16 \%$ Pellethane/zeolite solution.

Another problem encountered during casting was snagging of the support fabric between the casting drum and knife. The nylon support fabric was cut to size by our fabric supplier with a hot wire, which produces small beads of melted nylon along one edge. These beads are large enough to snag in the gap between the casting drum and knife, causing stoppages in the run or changes in the tension of the nylon fabric. Both effects produce nonuniformities in the sorbent layer surface. Stoppages in the run give more time for the casting solution to bleed through, which compounds the problem. Our solution was to knife-slit the support fabric to eliminate the small beads that cause the snagging. In this way both the bleed-through and snagging problems were eliminated, and we had few problems during casting. Seven casting runs were made; the conditions are listed in Table 26. 
Table 26. Conditions for Production-Scale Casting Runs

\begin{tabular}{|c|c|c|c||}
\hline $\begin{array}{c}\text { Casting Run } \\
\#\end{array}$ & $\begin{array}{c}\text { Solution } \\
\text { Viscosity (cp) }\end{array}$ & $\begin{array}{c}\text { Solution } \\
\text { Composition }\end{array}$ & $\begin{array}{c}\text { Run } \\
\text { Length (m) }\end{array}$ \\
\hline B206-5 & 13,850 & $\begin{array}{c}16 \% \text { polyurethane; } \\
16 \% \text { zeolite }\end{array}$ & 100 \\
\hline B206-6 & 19,000 & $\begin{array}{c}17 \% \text { polyurethane; } \\
17 \% \text { zeolite }\end{array}$ & 100 \\
\hline B206-7 & 22,500 & $\begin{array}{c}17 \% \text { polyurethane; } \\
17 \% \text { zeolite }\end{array}$ & 100 \\
\hline B206-8 & 22,000 & $\begin{array}{c}17 \% \text { polyurethane; } \\
17 \% \text { zeolite }\end{array}$ & 86 \\
\hline B206-9 & 19,000 & $\begin{array}{c}17.5 \% \text { polyurethane; } \\
17 \% \text { zeolite }\end{array}$ & 97 \\
\hline B206-10 & 16,250 & $\begin{array}{c}17 \% \text { polyurethane; } \\
17 \% \text { zeolite }\end{array}$ & 103 \\
\hline B206-11 & 16,250 & $\begin{array}{c}17 \% \text { polyurethane; } \\
17 \% \text { zeolite }\end{array}$ & 102 \\
\hline
\end{tabular}

\section{Coating}

Difficulties encountered in scaling up the coating procedure to the wide machine included improper tension and wrinkling of the fabric, and curling of the fabric edges. Poor edge-to-edge tension allows wrinkles to form length-wise in the fabric as the coating is dried in the oven. Wrinkles cause streaks in the PVA coating down the length of the fabric as coating solution pools in the wrinkles; this results in defective permselective layers. Curling of the fabric edges occurs when the edge rolls over and sticks to itself as the coating dries, resulting in a damaged band along the edge. We believe this is caused by differential swelling of the support fabric and sorbent layers as they are wetted by the coating solution.

To maintain edge-to-edge tension and prevent wrinkles, we installed inverted crown rollers on the coating machine. The inverted crown rollers did not eliminate wrinkles, but did reduce them to acceptable levels. The problem of fabric curling could not be solved without major modifications to our equipment. We concluded that a more efficient approach was for our laminator to coat and laminate the fabric in one step. Simple tests in our laboratory showed that coating and laminating in one step is feasible; samples prepared in this way by the laminator looked very good. 


\section{Laminating}

Because MTR does not have the capability to continuously laminate the two fabrics together, we looked for an outside laminator with the capability of laminating with aqueous solutions. We found one company with this capability, Uretek, which prepared very promising samples for us. Since our coating material, PVA, is also a good adhesive (see Section 5.3.4), the permselective layer can be formed at the same time the two fabrics are laminated together. Figure 17 illustrates the coating/lamination procedure.

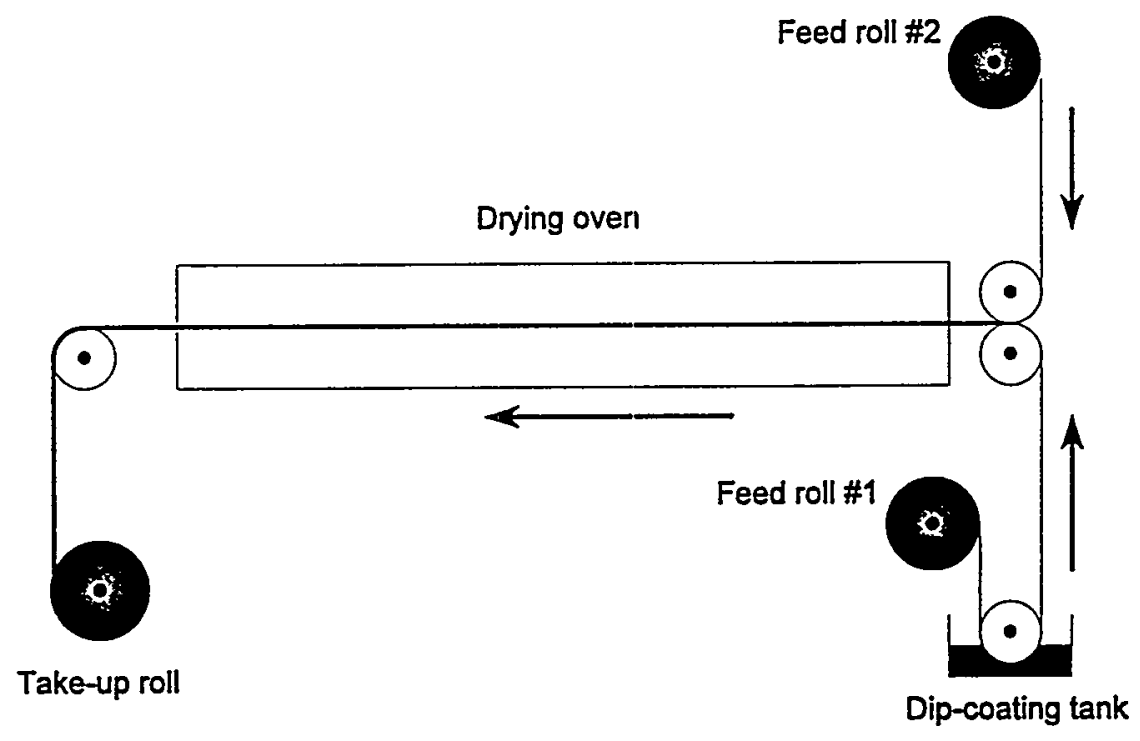

Figure 17. Schematic of laminating procedure used by Uretek.

Uretek produced two different laminated fabrics for us: the first (MTR-2) used our sorbentcoated nylon fabric for both layers, and the second (MTR-1) used our fabric for the outside layer and a lightweight nonwoven fabric on the inside. The advantage of the nonwoven fabric is that it is lighter and cheaper than our fabric, but, because it does not contain any sorbent, this laminate is not as protective as MTR-2. The appearance and feel of the laminated fabrics was very good; both types were made into prototype suits.

\section{PROTOTYPE SUIT PRODUCTION AND EVALUATION}

\subsection{Objective}

The objective of this task was to make prototype suits from the optimized fabrics, and to evaluate their ability to increase worker productivity while maintaining worker protection. To do this we contacted several manufacturers of protective clothing, eventually selecting one to make prototype suits. The suits were evaluated for chemical protection, physical characteristics, and effect on worker productivity. Using production cost estimates, we quantified the potential benefits of protective clothing made from our fabric. 


\subsection{Prototype Suit Production}

To produce prototype suits, we looked for a reputable protective clothing (PC) manufacturer with the capability to work with new materials, and an understanding of the market for different types of protective clothing. The specific characteristics needed in a manufacturer include:

- research and development capability

- in-house suit manufacturing capability

- broad range of products

- ongoing marketing activities

Discussions with different manufacturers provided us with valuable, practical information. For example, the importance of the ease with which seams can be made and sealed was impressed upon us. In response, we made sure that the fabric was durable, and that the permselective layer was protected from damage during heat-sealing procedures. Another concern voiced by manufacturers is the fabric color. The fabric produced with carbon as the sorbent is black; this undesirable because it produces wearer claustrophobia. Consequently, we used a zeolite sorbent that produces a white fabric.

Of the many PC manufacturers contacted, two were particularly attractive: DuraFab and Kappler Safety Group, Gantesville, AL. Eventually we chose Kappler to manufacture the prototype suits needed for Phase I. As well as suits made from the two MTR fabrics, identical suits were made from Saranex-coated Tyvek and from uncoated Tyvek for comparison. The suits were full-body coveralls as shown in Figure 18, including a hood, elastic wrists and ankles, front zipper, and sewn (but not taped) seams. The completed prototype suits received were the following:

- 7 suits from MTR 1 fabric (ripstop on both sides):

- 5 suits from MTR 2 fabric (ripstop/nonwoven):

- 6 suits from Saranex-coated Tyvek fabric:

- 6 suits from uncoated Tyvek fabric:
3 large, 4 extra large 3 large, 2 extra large 3 large, 3 extra large 3 large, 3 extra large 


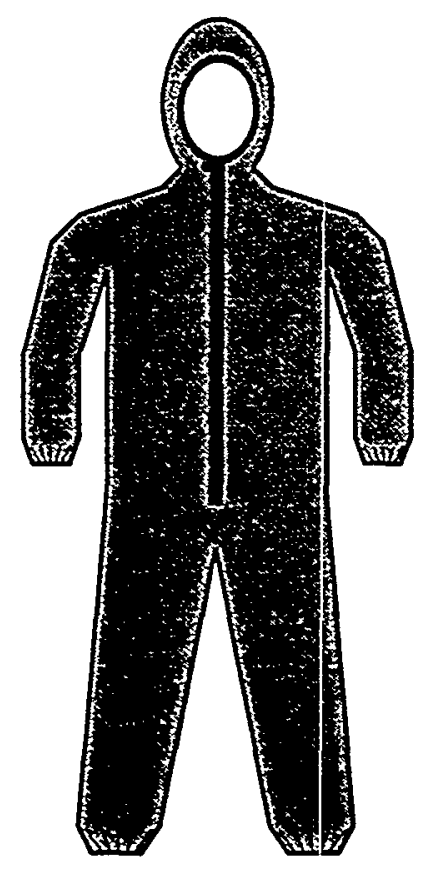

Figure 18. Full-body coverall style used for prototype suits.

\subsection{Prototype Suit Evaluation}

A rigorous test of a suit's ability to reduce heat stress is to perform human tests under controlled conditions. However, to obtain statistically reliable results with human subjects requires a large number of tests. This was beyond the scope and financial resources of the first phase of the project, so heat stress was evaluated with Thermal Manikin tests. In these tests, a manikin is dressed in the test suit. The manikin has holes throughout its "skin" through which water can be pumped to simulate sweating; the manikin's skin can also be heated, simulating body heat. The rate of heat transfer away from the manikin and through the protective clothing is measured. Because the conditions within the manikin (amount of sweat, body temperature) can be reliably controlled, few tests are required to get reproducible results. From this information, human performance models can be used to predict the length of time a person can work in the tested suit before heat stress restrictions require the worker to take a break. This allows a quantitative comparison of the productivity benefit of one suit over another.

The Thermal Manikin tests were performed by Arthur D. Little on the two prototype MTR suits and the two conventional suits (Saranex-coated Tyvek and uncoated Tyvek). The data were used by our consultant, Prof. Byron Jones from Kansas State University, to predict human performance. The results of the heat stress test are summarized in Table 27; the detailed test results are included in Appendix F. The MTR fabrics met our goals for water vapor transmission, and the 
Tyvek suits, which are completely water impermeable. We used a conservative $10 \%$ increase in productivity in our economic analysis.

Table 27. Summary Heat Stress Modeling Results for MTR's Protective Clothing and Conventional Protective Clothing (see Appendix F for details)

\begin{tabular}{|c|c|c|}
\hline Fabric & \multicolumn{2}{|c|}{ Test Results } \\
\hline $\begin{array}{l}\text { Water Vapor Transmission } \\
\text { (Project goal: } \text { MVTR }=800-1,000 \\
\mathrm{~g} / \mathrm{m}^{2} \cdot \text { day) }\end{array}$ & $\begin{array}{l}\text { MVTR - standard } \\
\left(\mathrm{g} / \mathrm{m}^{2} \cdot \text { day }\right)\end{array}$ & $\begin{array}{l}\text { MVTR - inverted } \\
\left(\mathrm{g} / \mathrm{m}^{2} \cdot \text { day }\right)\end{array}$ \\
\hline $\begin{array}{l}\text { MTR-1 } \\
\text { MTR-2 }\end{array}$ & $\begin{array}{l}816 \\
864\end{array}$ & $\begin{array}{l}1165 \\
1365\end{array}$ \\
\hline Heat Stress Modeling & $\begin{array}{l}\text { Work time for } \\
\text { moderate work at } 4 \mathrm{kcal} / \mathrm{min} \\
\text { (min) }\end{array}$ & $\begin{array}{l}\text { Work time for } \\
\text { heavy work at } 7 \mathrm{kcal} / \mathrm{min} \\
(\mathrm{min})\end{array}$ \\
\hline $70^{\circ} \mathrm{F}, 40 \% \mathrm{RH}^{*}$ & & \\
\hline MTR-1 & 26.5 & 14.0 \\
\hline MTR-2 & 25.5 & 13.5 \\
\hline Saranex-coated Tyvek & 23.5 & 13.0 \\
\hline Tyvek & 35.0 & 16.0 \\
\hline $90^{\circ} \mathrm{F}, 40 \% \mathrm{RH}$ & & \\
\hline MTR-1 & 18.5 & 12.0 \\
\hline MTR-2 & 17.0 & 10.5 \\
\hline Saranex-coated Tyvek & 16.0 & 10.0 \\
\hline Tyvek . & 20.0 & 11.5 \\
\hline $90^{\circ} \mathrm{F}, 90 \% \mathrm{RH}$ & & \\
\hline MTR-1 & 15.0 & 10.0 \\
\hline MTR-2 & 15.0 & 9.5 \\
\hline Saranex-coated Tyvek & 14.5 & 9.5 \\
\hline Tyvek & 16.0 & 10.0 \\
\hline
\end{tabular}

${ }^{*} \mathrm{RH}=$ relative humidity

\section{ECONOMIC ANALYSIS}

The estimated cost of the MTR fabric based on the current design is $\$ 5.40 / \mathrm{yd}^{2}$ for the MTR-1 material and $\$ 6.60 / \mathrm{yd}^{2}$ for the MTR-2 material. This leads to suit selling prices of $\$ 60-\$ 66$. For comparison, a Saranex-coated Tyvek suit has a selling price of $\$ 31$. This difference in suit cost is worthwhile if the MTR-fabric suits allow users to work longer without taking rests. Our calculations 
showed that, at current prices, the savings achieved based on the conservative thermal manikin results do not outweigh the extra costs if suits are discarded daily but do outweigh the extra cost if suits are worn for at least two days. We have also calculated that optimization of the production procedures during scale up of the manufacturing process used to fabricate MTR's fabric would reduce MTR's suit cost further. If so, MTR's suits would offer cost benefits even if discarded daily. Details of these calculations are given below.

To estimate the cost to manufacture our current fabrics, we assumed that we will make $250,000 \mathrm{~m}^{2}$ of fabric $(\sim 50,000$ completed suits $)$ per year with completely new equipment. Table 28 shows the quantities and the unit prices of materials needed for the two MTR fabrics, and Table 29 shows the capital cost of the facilities needed for this level of production. Table 30 shows the total fabric manufacturing (selling price) cost; these totals are $\$ 5.40 / \mathrm{yd}^{2}$ and $\$ 6.60 / \mathrm{yd}^{2}$ for fabrics MTR-1 and MTR-2, respectively. Compared with those of other protective fabrics, these prices are high. Barricade, a highly protective fabric manufactured by DuPont, sells for approximately $\$ 3.50 / \mathrm{yd}^{2}$; Saranex-coated Tyvek sells for approximately $\$ 1.20 / \mathrm{yd}^{2}$; and Tyvek sells for less than $\$ 1.00 / \mathrm{yd}^{2}$. However, our fabric offers the advantage of the greater worker comfort and productivity achievable with a cool fabric. 
Table 28. Material Quantities Needed for MTR Fabrics

\begin{tabular}{|c|c|c|c|c|}
\hline \multicolumn{5}{|c|}{ MTR-1 } \\
\hline \multirow[b]{2}{*}{ Material } & \multirow[b]{2}{*}{ Unit Cost* } & \multicolumn{2}{|c|}{ Amount Needed } & \multirow{2}{*}{$\begin{array}{c}\text { Cost } \\
\text { of finished fabric } \\
\left(\$ / \mathrm{m}^{2}\right)\end{array}$} \\
\hline & & $\begin{array}{c}\text { Per } \mathrm{m}^{2} \text { of } \\
\text { Finished Fabric }\end{array}$ & $\begin{array}{c}\text { Per Year for } \\
250,000 \mathrm{~m}^{2} / \mathrm{yr}\end{array}$ & \\
\hline \multirow{10}{*}{\begin{tabular}{|} 
Support Fabric \\
Sorbent Layer \\
Solvent \\
Polymer \\
Sorbent \\
Total \\
Permselective Layer \\
Crosslinker \\
Polymer \\
Total \\
TOTAL
\end{tabular}} & \multirow{5}{*}{ 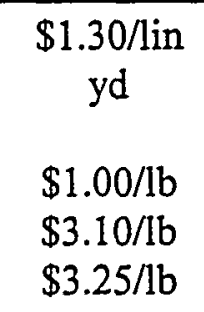 } & 1.20 lin yd & 300,000 lin $y d$ & 1.56 \\
\hline & & $023 \mathrm{lb}$ & $562501 \mathrm{~h}$ & 023 \\
\hline & & $0.05 \mathrm{lb}$ & $12,665 \mathrm{lb}$ & $\begin{array}{l}0.23 \\
0.16\end{array}$ \\
\hline & & $0.05 \mathrm{lb}$ & $12,665 \mathrm{lb}$ & $\underline{0.16}$ \\
\hline & & & & 0.55 \\
\hline & \multirow{5}{*}{$\begin{array}{l}\$ \overline{15 / 1 \mathrm{~b}} \\
\$ 1.51 / 1 \mathrm{~b}\end{array}$} & \multirow{5}{*}{$\begin{array}{c}0 . \overline{0} \\
0.068 \mathrm{lb}\end{array}$} & \multirow{5}{*}{$\begin{array}{c}\overline{1,700 \mathrm{lb}} \\
17,000 \mathrm{lb}\end{array}$} & \\
\hline & & & & 0.01 \\
\hline & & & & $\underline{0.10}$ \\
\hline & & & & 0.12 \\
\hline & & & & 2.22 \\
\hline & \multicolumn{3}{|c|}{ MTR-2 } \\
\hline \multirow[b]{2}{*}{ Material } & \multirow[b]{2}{*}{ Unit Cost* } & \multicolumn{2}{|c|}{ Amount Needed } & \multirow{2}{*}{$\begin{array}{c}\text { Cost } \\
\text { of finished fabric } \\
\left(\$ / \mathrm{m}^{2}\right)\end{array}$} \\
\hline & & $\begin{array}{c}\text { Per } \mathrm{m}^{2} \text { of } \\
\text { Finished Fabric }\end{array}$ & $\begin{array}{c}\text { Per Year for } \\
250,000 \mathrm{~m}^{2} / \mathrm{yr}\end{array}$ & \\
\hline Support Fabric & $\$ 1.85$ lin & 1.20 lin yd & 300,000 lin yd & 2.21 \\
\hline $\begin{array}{r}\text { Sorbent Layer } \\
\text { Solvent }\end{array}$ & & $0.45 \mathrm{lb}$ & $112,500 \mathrm{lb}$ & 0.45 \\
\hline Polymer & $\$ 1.00 / \mathrm{b}$ & $0.10 \mathrm{lb}$ & $25,330 \mathrm{lb}$ & 0.31 \\
\hline Sorbent & $\$ 3.10 / \mathrm{b}$ & $0.10 \mathrm{lb}$ & $25,330 \mathrm{lb}$ & $\underline{0.33}$ \\
\hline Total & $\$ 3.25 / 1 \mathrm{~b}$ & & & 1.09 \\
\hline \multirow{4}{*}{$\begin{array}{c}\text { Permselective Layer } \\
\text { Crosslinker } \\
\text { Polymer } \\
\text { Total }\end{array}$} & \multirow{5}{*}{$\begin{array}{l}\$ 2.15 / \mathrm{lb} \\
\$ 1.51 / \mathrm{lb}\end{array}$} & \multirow{5}{*}{$\begin{array}{l}0.007 \mathrm{lb} \\
0.068 \mathrm{lb}\end{array}$} & \multirow{5}{*}{$\begin{array}{c}1,700 \mathrm{lb} \\
17,000 \mathrm{lb}\end{array}$} & \\
\hline & & & & 0.01 \\
\hline & & & & $\underline{0.10}$ \\
\hline & & & & 0.12 \\
\hline TOTAL & & & & 3.42 \\
\hline
\end{tabular}

*Based on 1996 quotes from suppliers. 
Table 29. Capital Costs for Commercial-Scale Fabric Manufacturing Equipment. Estimates are based on the cost of similar equipment built by MTR and are accurate to $\pm 25 \%$.

\begin{tabular}{|c|c|c|}
\hline Item & $\begin{array}{c}\text { Capital Costs } \\
\mathbf{(} \mathbf{(})\end{array}$ & $\begin{array}{c}\text { Unit Cost }^{\mathbf{b}} \\
\left(\$ / \mathbf{m}^{2}\right)\end{array}$ \\
\hline Caster & 200,000 & 0.40 \\
Laminator/dryer & 300,000 & 0.60 \\
Miscellaneous & $\underline{100,000}$ & $\underline{0.20}$ \\
TOTAL & 600,000 & 1.20 \\
\hline
\end{tabular}

a Assumes a capacity of $250,000 \mathrm{~m}^{2} /$ year

b Assumes a two-year capital payback time

Table 30. Total Fabric Manufacturing Cost

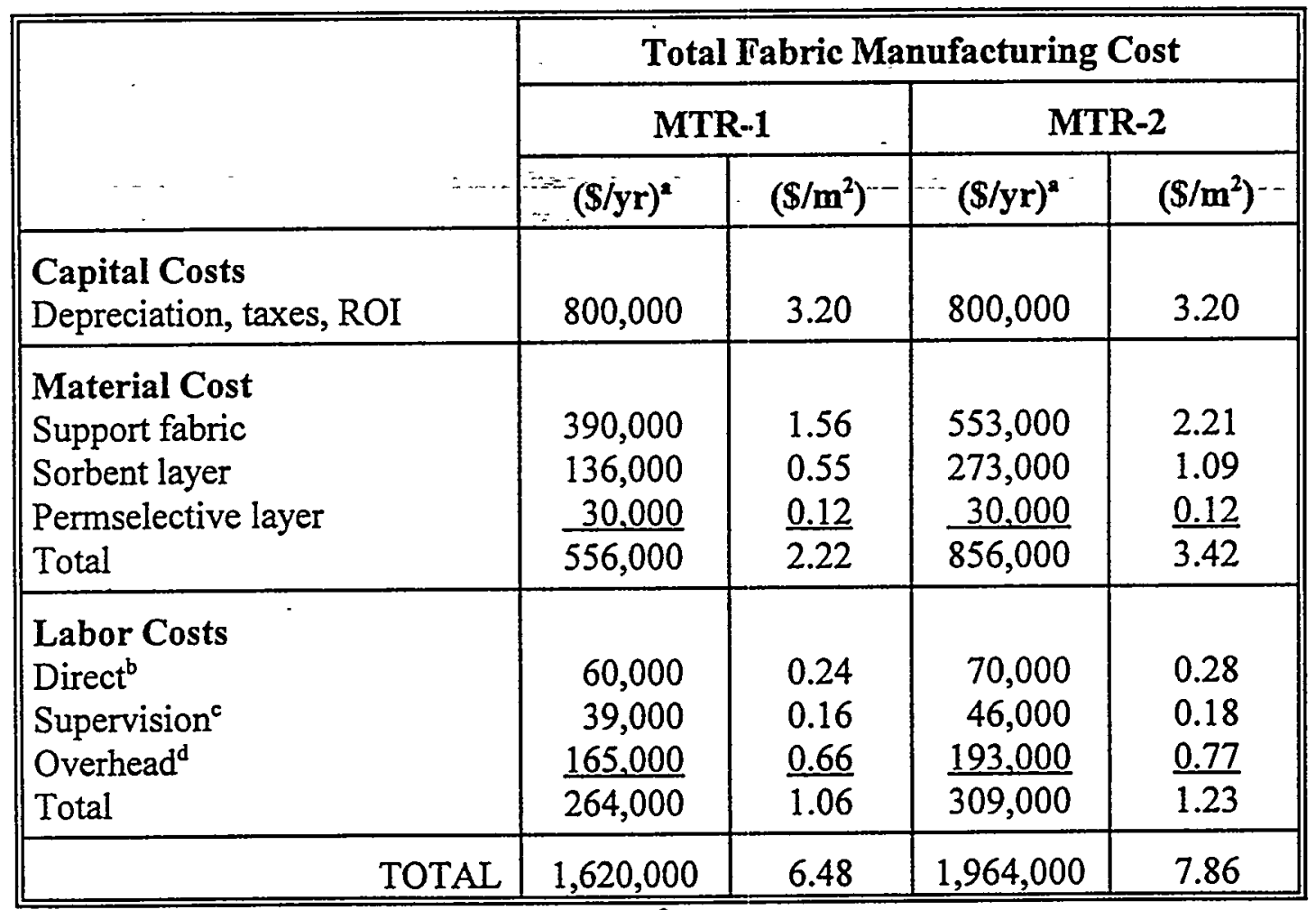

${ }^{a}$ Assumes annual production of $250,000 \mathrm{~m}^{2} /$ year.

${ }^{b}$ Based on labor rate of $\$ 15$ hour

c $65 \%$ of direct labor

d $165 \%$ of direct labor and supervision

The estimate of the completed suit price is based on three components: fabric cost, manufacturing (cutting/sewing/seaming) cost, and distributor markup. For a total body coverall 
(including hood and booties) with strapped (sewn and heat-sealed) seams, 4.2 square meters ( 5 square yards) of fabric are used per suit. We estimate the manufacturing component to be $\$ 23$ ( $\$ 8$ to sew the suit and $\$ 15$ to seal the seams), and the distributor markup to be $\$ 10$ per suit. Based on these estimates, the selling prices for suits made from the MTR fabrics will be $\$ 60$ and $\$ 66$ for fabrics MTR-1 and MTR-2, respectively.

To quantify the benefits of a cool suit, we estimated the total worker cost for eight hours of productivity. The worker cost consists of direct labor costs (wages); indirect costs (worker's benefits and other expenses, support costs such as supervision and administration, and the cost of equipment); and the cost of protective clothing. We have estimated the direct and indirect costs to be $\$ 15 /$ hour each. Table 31 shows the total cost for a productive hour of work, where a productive hour is an hour that a worker is actually working. For example, if a worker takes eight 20-minute breaks to prevent heat stress in an 8-hour workday, approximately 5.4 productive hours of work are performed.

To determine the cost for 8 productive hours using protective clothing, we assumed a 10minute break after each period of work. The length of a work period depends on the temperature and humidity conditions and on the strenuousness of the work being performed. For this analysis, we assumed a work period equal to the average of the moderate and heavy work values determined by heat stress modeling (see Table 25). Thus, a worker wearing a Saranex-coated Tyvek suit will have 4.4 productive hours per 8-hour work day, and workers wearing suits made from MTR fabrics will have 4.8 and 4.6 productive hours, that is, $4.5 \%$ longer for the MTR-2 suit and $9 \%$ longer for the MTR-1 suit. The cost savings achieved by MTR suits compared to Saranex-coated Tyvek for suits exchanged daily and weekly (5 days wear) are shown in Table 31 . The calculations in Table 31 show that, at today's suit cost, the MTR suits are cost effective if exchanged once every 2 to 5 days, but are not cost effective if exchanged daily. 
Table 31. Cost-Benefit Calculations for the MTR-1 and MTR-2 Suits Compared to Saranex-Coated Tyvek Suits, Assuming Suits are Exchanged Daily and Weekly.

\begin{tabular}{|c|c|c|c|c|c|c|}
\hline 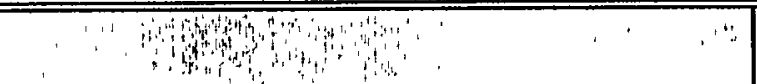 & Suitsiex & hanged D & & Suits Exch & nged Wwe & \\
\hline Parameter & $\begin{array}{c}\text { Saranex- } \\
\text { Coated Tyvek }\end{array}$ & MTR-1 & MTR-2 & $\begin{array}{c}\text { Saranex-Coated } \\
\text { Tyvek }\end{array}$ & MTR-1 & MTR-2 \\
\hline Productive hours (per 8-hour workday) & 4.4 & 4.8 & 4.6 & 4.4 & 4.8 & 4.6 \\
\hline Productive hours (per 5-day week) & 22 & 24 & 23 & 22 & 24 & 23 \\
\hline Total labor cost $\$ /$ week* & 1,200 & 1,200 & 1,200 & 1,200 & 1,200 & 1,200 \\
\hline $\begin{array}{l}\text { Suit cost } \$ / \text { week } \\
\text { Suits used/week } \\
\text { Suit cost }(\$) \\
\text { Cost } \$ / \text { week }\end{array}$ & $\begin{array}{r}5 \\
31.20 \\
156\end{array}$ & $\begin{array}{r}5 \\
60 \\
300\end{array}$ & $\begin{array}{r}5 \\
66 \\
330\end{array}$ & $\begin{array}{c}1 \\
31.20 \\
31\end{array}$ & $\begin{array}{r}1 \\
60 \\
60\end{array}$ & $\begin{array}{r}1 \\
66 \\
66\end{array}$ \\
\hline Total cost $\$ /$ week & 1,356 & 1,500 & 1,530 & 1,231 & 1,260 & 1,266 \\
\hline Total cost \$/productive hour & 61.6 & 62.5 & 66.5 & 56.0 & 52.5 & 55.0 \\
\hline
\end{tabular}

*Direct labor cost at $\$ 15 /$ hour $=\$ 600$

Indirect labor cost at $\$ 15 /$ hour $=\$ 600$ 
However, some moderate cost reductions and a slight improvement in water vapor transmission rate could make the MTR fabric very competitive with conventional chemical protective fabrics. Cost reduction is achievable in several areas. The previous analysis assumes installation of manufacturing equipment to produce the current fabric at MTR's facilities. The first major cost reduction comes from eliminating most of the manufacturing equipment capital costs by identifying a company that already has production equipment in place. This will reduce the capital expenses from $\$ 600,000$ to $\$ 100,000$ (still needed for equipment modification), reducing fabric cost by about $\$ 1.00 / \mathrm{m}^{2}$.

The second area of cost reduction is in the support fabric: for every square yard of completed fabric, two yards of support fabric are needed (because there are two layers of support fabric in our final fabric). The cost of the support fabric accounts for $65 \%$ of the total material costs. Using a less expensive fabric (probably a nonwoven) should allow reductions in the fabric price of at least $\$ 1.00$. A third, less important cost reduction would be replacing the solvent used for casting the microporous layer with a less expensive solvent; this should reduce fabric costs by almost $\$ 0.20$ per lb. Table 32 summarizes the economic analysis with this "improved" MTR fabric (labeled MTRimp), compared with current MTR fabrics. The fabric price of MTR-imp is $\$ 5.43 / \mathrm{m}^{2}\left(\$ 4.54 / \mathrm{yd}^{2}\right)$, and the selling price for a suit made from this improved MTR fabric is $\$ 56$.

Table 32. Total Fabric Manufacturing Cost

\begin{tabular}{|l|c|c|c||}
\hline & \multicolumn{3}{|c|}{ Total Fabric Manufacturing Cost } \\
\cline { 2 - 4 } & MTR-1 & MTR-2 & MTR-imp \\
\hline Capital Costs $\left(\$ / \mathrm{m}^{2}\right)$ & & & \\
Depreciation, taxes, ROI & 3.20 & 3.20 & 2.20 \\
\hline Material Cost $\left(\$ / \mathrm{m}^{2}\right)$ & & & \\
Support fabric & 1.56 & 2.21 & 1.20 \\
Sorbent layer & 0.55 & 1.09 & 0.86 \\
Permselective layer & $\underline{0.12}$ & $\underline{0.12}$ & $\underline{0.12}$ \\
Total & 2.22 & 3.42 & 2.18 \\
\hline Labor Costs $\left(\$ / \mathrm{m}^{2}\right)$ & & & \\
Direct & 0.24 & 0.28 & 0.24 \\
Supervision & 0.16 & 0.18 & 0.16 \\
Overhead & $\underline{0.66}$ & $\underline{0.77}$ & $\underline{0.66}$ \\
Total & 1.06 & 1.23 & 1.06 \\
\hline TOTAI $\left(\$ / \mathrm{m}^{2}\right)$ & 6.48 & 7.86 & 5.43 \\
& 5.42 & 6.57 & 4.54 \\
\hline
\end{tabular}

${ }^{a}$ Assumes annual production of $250,000 \mathrm{~m}^{2} / \mathrm{year}$. 
We also believe that a little optimization work on the commercial equipment will improve the MVTR of the MTR fabric. In preparation of rolls of fabric by our laminator, there was no opportunity to optimize the laminating conditions (laminating speed, drying conditions, laminating solution concentration and viscosity, etc.); a limited optimization program should yield some increase in MVTR, and possibly in chemical protection as well. We assume that we can increase the MVTR enough to allow 5.5 productive hours of work per day, compared to 4.4 for Saranexcoated Tyvek, 4.8 and 4.6 for MTR-1 and MTR-2, respectively. While it is not possible to directly correlate MVTR to productivity (heat stress depends on the garment fit, fabric insulative properties, and other factors as well as on MVTR), we believe that this expected improvement in productive time is reasonable based on the productive time achieved with Tyvek $(-5.5$ productive hours per day) which had a much lower MVTR in our laboratory-scale fabrics. Based on this assumption, the calculations in Table 33 show that MTR suit produced from the improved fabric (MTR-imp) becomes very cost effective (labor costs reduced more than $10 \%$ over Saranex-coated Tyvek suits) even when exchanged daily.

Table 33. Cost-Benefit Calculations for the MTR-1, MTR-2, and MTR-Imp Suits Compared to Saranex-Coated Tyvek Suits.

\begin{tabular}{|c|c|c|c|c|}
\hline \multirow[b]{2}{*}{ 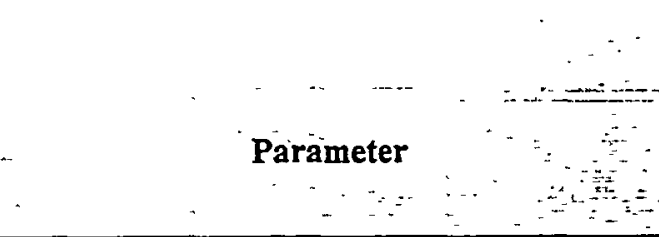 } & \multicolumn{4}{|c|}{ Suits Exchanged Daily } \\
\hline & $\begin{array}{l}\text { Saranex- } \\
\text { Coated } \\
\text { Tyvek }\end{array}$ & MTR-1 & MTR-2 & MTR-Imp \\
\hline Productive hours (per 8-hour workday) & 4.4 & 4.8 & 4.6 & 5.5 \\
\hline Productive hours (per 5-day week) & 22 & 24 & 23 & 27.5 \\
\hline Total labor cost \$/week* & 1,200 & 1,200 & 1,200 & 1,200 \\
\hline $\begin{array}{l}\text { Suit cost } \$ / \text { week } \\
\text { Suits used/week } \\
\text { Suit cost }(\$) \\
\text { - Cost } \$ / \text { week }\end{array}$ & $\begin{array}{r}5 \\
31.20 \\
156\end{array}$ & $\begin{array}{r}5 \\
60 \\
300\end{array}$ & $\begin{array}{r}5 \\
66 \\
330\end{array}$ & $\begin{array}{r}5 \\
56 \\
280\end{array}$ \\
\hline Total cost $\$ /$ week & 1,356 & 1,500 & 1,530 & 1,400 \\
\hline Total cost (\$/productive hour) & 61.6 & 62.5 & 66.5 & 53.8 \\
\hline
\end{tabular}

*Direct labor cost at $\$ 15 /$ hour $=\$ 600$

Indirect labor cost at $\$ 15 /$ hour $=\$ 600$

Several companies have the capability to make these improvements in our fabric. In partnership with one of these, we expect to be able to produce an attractive alternative to currently available chemically protective fabrics. 


\section{CONCLUSIONS AND RECOMMENDATIONS}

The fabrics produced during this project were a significant advancement in state-of-the-art protective fabrics. No currently available fabrics combine protection against vapor and liquid chemical hazards with reduced potential for heat stress by allowing water vapor to permeate the fabric. The fabrics developed in this project meet the water vapor transmission rate goals (greater than $800 \mathrm{~g} / \mathrm{m}^{2}$.day) and provide chemical protection equivalent to currently used non-waterpermeable chemical protective suits. Significantly, these results were achieved in a practical fabric that is strong, durable, flexible, lightweight, and easy to manufacture into a suit.

The goal for our fabric is to increase worker productivity; thus, the true test of fabric success is whether the increase in productivity provided by the fabric offsets the higher cost of suits made from it. (Our fabrics are more expensive than currently used, non-water-permeable suits). The estimated productivity increase (based on measurements with a thermal manikin) with the MTR fabrics was approximately $10 \%$ over the productivity achieved with conventional chemical protective fabrics. This is a very conservative improvement in productivity, given the large difference in water vapor transmission between occlusive (non-water-vapor-permeable) suits and MTR's water-vapor-permeable suits. Based on this value, the MTR suit is only cost effective if worn for two days or more.

However, we believe that moderate reductions in cost and a small increase in water vapor transmission of these fabrics will result in a fabric that is economically attractive to users of chemical protective clothing. The cost reductions would be achieved primarily by finding a fabric manufacturer that has equipment capable of producing this fabric (reducing capital costs), and by finding a support fabric that is less expensive than our current woven fabric (the major material cost of our fabric). The increase in water vapor transmission can be achieved by optimizing the laminating process.

We recommend that these steps-finding a suitable manufacturer and optimizing the fabric on their equipment-should be taken before beginning large-scale field tests. We believe the chances of achieving the required fabric cost reductions are good, and that the resulting fabric has a large potential for use at DOE facilities, and in a variety of industrial applications throughout the United States.

\section{REFERENCES}

1. J.O. Stull, "Full-Body Protection and Standards," in Guidelines for the Selection of Chemical Protective Clothing, 3rd ed., American Conference of Governmental Industrial Hygienists, Inc., Cincinnati, OH (February 1987).

2. J.F. Rekus, "Can You Take The Heat," Occupational Health and Safety.

3. S. Minter, "Cooling Off Heat Stress," Occupational Hazards, (June 1994).

4. M. Hans, "Wage War Against Heat Stress," Safety and Health, (June 1994).

5. J. Huck, "The Physiology of Heat Stress," Safety and Protective Fabrics, (August 1993). 
6. American Conference of Government Industrial Hygienists, "1994-1995 Threshold Limit Value for Chemical Substances and Physical Agents and Biological Exposure Indices," ACGIH, Cincinnati, OH (1994).

\section{BIBLIOGRAPHY}

1. "Protective Clothing Based on Permselective Membrane and Carbon Adsorption," presented at Opportunities ' 95 - Environmental Technology Through Small Businesses, Morgantown, WV (November 16-17, 1994).

2. "Protective Clothing Based on Permselective Membrane and Carbon Adsorption," presented at Environmental Technology Through Industry Participation, Morgantown, WV (October 3-5, 1995).

3. "Protective Clothing Based on Permselective Membrane and Carbon Adsorption," presented at Sixth International Symposium on Performance of Protective Clothing, Sponsored by ASTM, Orlando, FL (June 18-19, 1996), 


\section{APPENDIX A: FABRIC EVALUATION TEST PROCEDURES}

1) Sorbent Capacity

2) Organic Vapor Permeation

3) Moisture Vapor Transmission (MVTR) 


\section{CARBON TETRACHLORIDE VAPOR SORPTION TEST PROCEDURE}

This test procedure was developed by MTR to evaluate the relative organic sorption capacity of different grades of activated carbons and other sorption agents before and after their incorporation into membrane fabric materials.

\section{A. Materials:}

1. Oven, mechanical-convection type

2. Sorption chamber, leak-free

3. Analytical balance

4. Carbon tetrachloride

5. Pyrex dish, 2 liter capacity $(8$ in $\times 8$ in $\times 2$ in $)$

6. Weighing dish, aluminum

7. Thermometer

8. Fume hood

B. Procedure:

1. Determine the sorbent density in the fabric material $\left(\mathrm{g} / \mathrm{cm}^{2}\right)$, using the total mass of the coated fabric, the mass of the uncoated fabric, and the polymer-to-sorbent mass ratio in the casting solution.

2. Trace and cut a 10-cm square of coated fabric. Include a blank sample of the coated fabric containing no sorbent. To measure the capacity of the pure sorbent, use 0.5 -gram samples in aluminum dishes.

3. Pre-treat the samples in the mechanical convection oven at $80^{\circ} \mathrm{C}$ for 18 hours to drive off residual organic compounds that may be present in the fabric from the casting operation.

4. Weigh and record the initial mass of the fabric samples. Place in horizontal racks.

5. Wearing appropriate respiratory protection, place the fabric samples in the carbon tetrachloride $\left(\mathrm{CCl}_{4}\right)$ sorption chamber (inside a fume hood). The chamber contains air saturated with $\mathrm{CCl}_{4}$ vapor at room temperature (by means of a dish of $\mathrm{CCl}_{4}$ liquid). Leave samples in the chamber for 18 hours.

6. After 18 hours, remove one sample at a time from the sorption chamber and weigh. The difference in mass before and after exposure to $\mathrm{CCl}_{4}$ in the test chamber is the overall mass of $\mathrm{CCl}_{4}$ sorbed by the coated fabric. Subtract from this number the mass of $\mathrm{CCl}_{4}$ sorbed by the blank coated fabric without sorbent to obtain the sorption capacity of the active sorbent material in the membrane matrix (grams $\mathrm{CCl}_{4} /$ gram sorbent).

7. Compare this sorption capacity to that of the pure sorbent samples, and determine the percent loss in sorptive capacity caused by incorporation into the membrane matrix. 


\section{ORGANIC VAPOR PERMEATION TEST PROCEDURE}

This procedure is based on the open-loop testing configuration of Procedure A (liquid test chemicals) of ASTM F739-91 "Standard Test Method for Resistance of Protective Clothing Materials to Permeation by Liquids or Gases Under Conditions of Continuous Contact."

A. Materials:

1. Standard ASTM Permeation Test Cell (Pesce Lab Sales)

2. Flame Ionization Detector (SRI, stand-alone FID, model no. 8680-10)

3. Strip chart recorder (Linear Instruments Corp., model no. 155)

4. Analytical balance (Mettler model H80, $160 \mathrm{~g} \times 0.1 \mathrm{mg}$ )

5. Dial thickness gauge (Mituyoyo model no. $7326,0.050$ in $\times 0.0001$ in)

6. Dichloromethane, $\mathrm{CH}_{2} \mathrm{Cl}_{2}$ (liquid test chemical)

7. Hydrogen, air and nitrogen gas cylinders (FID gases and collection medium, respectively)

8. Bubble flowmeter (20 cc flow tube and electronic timer)

9. Laboratory fume hood.

B. Procedure:

1. Calibrate the FID detector using standard mixtures of dichloromethane $\left(\mathrm{CH}_{2} \mathrm{Cl}_{2}\right)$ vapor in nitrogen at concentrations of 10,200 , and $3,000 \mathrm{ppm}$ by volume. Adjust the flow rate of the standard gas mixture to $50 \mathrm{~cm}^{3} / \mathrm{min}$, the sample gas flow rate that will be used in the permeation test. Heat the line connecting the test cell to the detector to $32^{\circ} \mathrm{C}$, as required in the permeation test to prevent vapor condensation. Note: Install the FID detector in close proximity to the permeation test cell, both inside a fume hood.

2. Measure and record the thickness of the fabric material.

3. Trace and cut a sample of fabric 2 inches in diameter. Weigh, determine the mass per unit area of the sample, and record.

4. Trace and cut a circle of fabric approximately 4.75 inches in diameter. Place the sample between the two PTFE gaskets of the permeation test cell, and mount it by tightening the three flange bolts. Trim the fabric at the bolts to prevent curling during attachment to the cell. Verify that the normally outside surface of the fabric faces the challenge chamber of the test cell. The active area of the fabric sample in the Pesce test cell is $20.5 \mathrm{~cm}^{2}$.

5. Mount the test cell in its holder and pass $50 \mathrm{~cm}^{3} / \mathrm{min}$ of nitrogen carrier gas through the collection or permeate chamber, and into the FID detector. Start and zero the FID detector and the chart recorder. Note: To examine the effect of water vapor on the permeation resistance of the fabric, first bubble the nitrogen carrier stream through a water reservoir at room temperature prior to the test cell. 
6. Start the permeation test by charging the challenge chamber of the Pesce cell with liquid $\mathrm{CH}_{2} \mathrm{Cl}_{2}$ up to the mark on the fill port. Begin timing the test and initial the recorder as soon as the liquid is introduced into the cell. Start the recorder at the maximum resolution of 0-1 $\mathrm{mV}$.

7. Monitor the course of the experiment and record both the actual and the normalized breakthrough times. The actual breakthrough time is the elapsed time between initial contact of the $\mathrm{CH}_{2} \mathrm{Cl}_{2}$ with the outside surface of the fabric and detection by the FID detector. The FID will detect $\mathrm{CH}_{2} \mathrm{Cl}_{2}$ at concentrations in nitrogen as low as $0.5 \mathrm{ppm}$, which is the system detection limit (SDL) of the FID unit. At this concentration in the collection stream, the permeation rate of $\mathrm{CH}_{2} \mathrm{Cl}_{2}$ through the fabric sample is $0.004 \mu \mathrm{g} / \mathrm{cm}^{2} \cdot \mathrm{min}$ (the minimum detectable permeation rate (MDPR) of the FID). The normalized breakthrough time is the elapsed time between initial contact of the $\mathrm{CH}_{2} \mathrm{Cl}_{2}$ with the outside surface of the fabric and the point at which the permeation rate reaches $0.1 \mu \mathrm{g} / \mathrm{cm}^{2} \cdot \min$. The $\mathrm{CH}_{2} \mathrm{Cl}_{2}$ concentration at which normalized permeation occurs is $11.5 \mathrm{ppm}$.

8. Continue monitoring the test by decreasing the resolution of the chart recorder as the concentration of $\mathrm{CH}_{2} \mathrm{Cl}_{2}$ in the detector increases beyond the range of the current resolution. Allow the test to proceed until steady-state permeation is achieved. At this point, the $\mathrm{CH}_{2} \mathrm{Cl}_{2}$ concentration in the collection stream has stabilized with respect to time. Calculate and record the steady-state permeation rate using the formula:

Permeation Rate $=$ Steady-State Concentration $\cdot($ Flow rate/Area $) \cdot$ Vapor Density

(Vapor density of $\mathrm{CH}_{2} \mathrm{Cl}_{2}$ at $25^{\circ} \mathrm{C}$ is $0.00347 \mathrm{~g} / \mathrm{cm}^{3}$.) 


\section{MOISTURE VAPOR TRANSMISSION TEST PROCEDURE (STANDARD OR INVERTED}

This procedure is based on the Water Method of ASTM E96-94 "Standard Test Methods for Water Vapor Transmission of Materials."

A. Materials:

1. Weighing dish, aluminum, $63 \mathrm{~mm}$ dia. $\times 17.5 \mathrm{~mm}$ ht. (Fisher Scientific Cat. No. 08-732$\left.5^{\circ} \mathrm{C}\right)$

2. Oven, mechanical-convection type (Precision Scientific Model No. 18EM)

3. Thermohygrometer (Cole-Parmer Instrument Co., Cat. No. 03310-40)

4. Pyrex dish, 3 liter capacity ( 13 in $\times 9$ in $\times 2$ in)

5. Magnesium Nitrate Hexahydrate $\left(\mathrm{Mg}\left(\mathrm{NO}_{3}\right)_{2} \cdot 6 \mathrm{H}_{2} \mathrm{O}\right), 1-3 \mathrm{Kg}$, for constant humidity solution

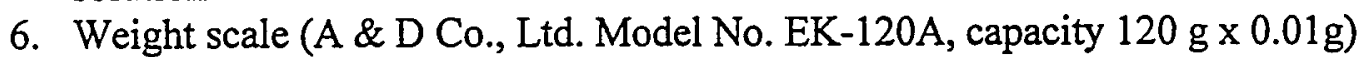

7. Adhesive/sealant (Silicone Rubber, GE Translucent RTV 108)

8. Distilled water, $30 \mathrm{ml}$ per sample

9. $50 \mathrm{ml}$ graduated cylinder

10. Weights, $200-400 \mathrm{~g}$

B. Procedure (Dry Surface Test):

1. Trace and cut a circle of fabric approximately 3 inches in diameter for each dish. Use three random samples of each fabric type.

2. Apply a thin, narrow coat of RTV sealant around the flange of the dish, to cover approximately $75 \%$ of its circumference. Place the fabric sample on top of the dish, and press down using an inverted empty dish with a $200-400 \mathrm{~g}$ weight on top. Verify that the inside surface of the fabric faces the water in the dish.

3. Wait about 20-30 minutes for the sealant to set. The active area of the fabric sample is approximately $30 \mathrm{~cm}^{2}$. Trim the excess fabric off of the perimeter edge.

4. Pour $30 \mathrm{ml}$ of distilled water from a graduated cylinder into a dish. Avoid any water contact with the fabric. Use the weight scale and a dropper to measure $30.0 \mathrm{~g}$, and record the actual mass of water used on the attached test sheet. The dish is now about half-full with the liquid level approximately $0.35 \mathrm{in}$. from the fabric sample. Seal the remaining $25 \%$ of the circumference of the fabric with RTV. Press down again and wait about 20-30 minutes for the sealant to set.

5. Weigh and record the initial mass of each dish assembly in the test sheet. Place dishes in a horizontal rack after weighing. 
6. Place the rack in an oven (samples upward for the "standard" method or downward for the "inverted" method), maintained at $90^{\circ} \mathrm{F}\left(32^{\circ} \mathrm{C}\right)$ and $50 \%$ relative humidity. Maintain temperature within $1^{\circ} \mathrm{F}\left(0.6^{\circ} \mathrm{C}\right)$, and relative humidity within $2 \%$ of these specifications. Record the date, the time, and the temperature and relative humidity of the oven on the test sheet. The temperature control knob of Precision Scientific model no. 18EM oven must be set to 1.0 , and the hole on top of the oven sealed with a rubber stopper. A constant relative humidity of $51-52 \%$ is achieved by placing a saturated solution of magnesium nitrate hexahydrate $\left.\left(\mathrm{Mg} \mathrm{NO}_{3}\right)_{2} \cdot 6 \mathrm{H}_{2} \mathrm{O}\right)$, in the 3-liter pyrex dish inside the oven during the test. This solution is prepared by dissolving 2 kilograms of magnesium nitrate hexahydrate in approximately 1.3 liters of water.

7. Leave the samples in the oven overnight. Record the total mass of each dish assembly as well as the temperature and relative humidity readings every day for at least 3 days. Calculate and record the moisture vapor transmission rate (MVTR) of each fabric sample. Use the following formula:

MVTR $=$ Mass change $/$ Time interval $\cdot$ Fabric Area

C. Procedure (Wetted Surface Test):

The procedure is identical to the dry-surface procedure, except that in step 5 , first place the dish assemblies in the rack in an inverted position over support rods. By doing so, water covers the entire inner surface of the fabric, while the outer surface of the fabric is in direct contact with the air. During weighings, place the dishes in the balance in the upright position. 


\section{APPENDIX B: CHEMICAL RESISTANCE OF PROTECTIVE CLOTHING}

MATERIALS 


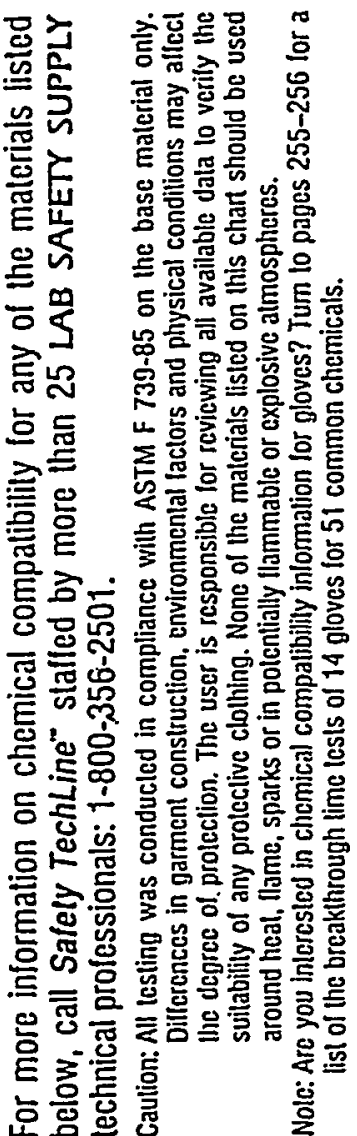

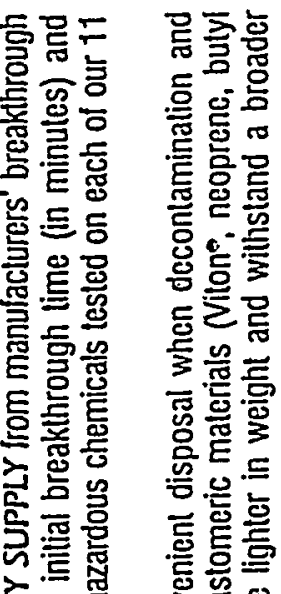

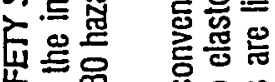

安

흐뮹등

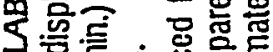

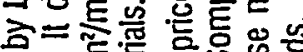

잉 응

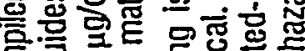

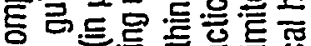

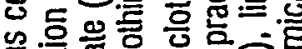

范 둔

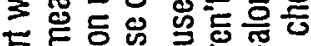

종

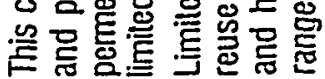

\begin{tabular}{|c|c|}
\hline 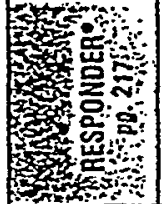 & 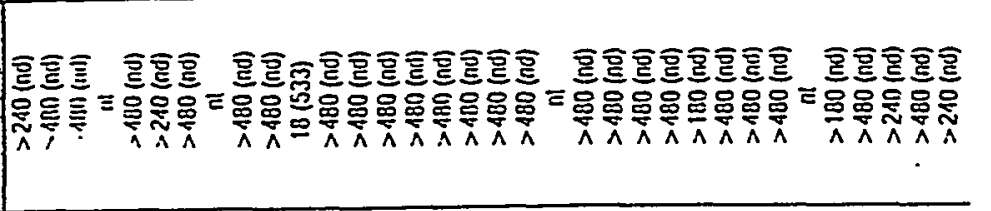 \\
\hline 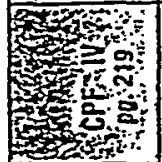 & 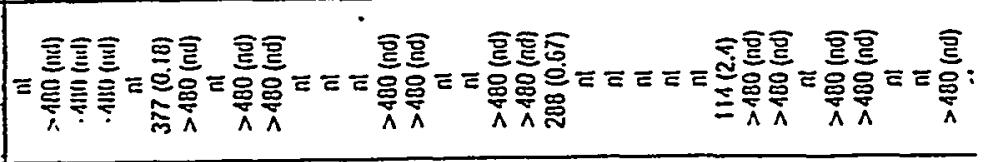 \\
\hline 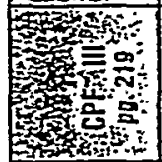 & 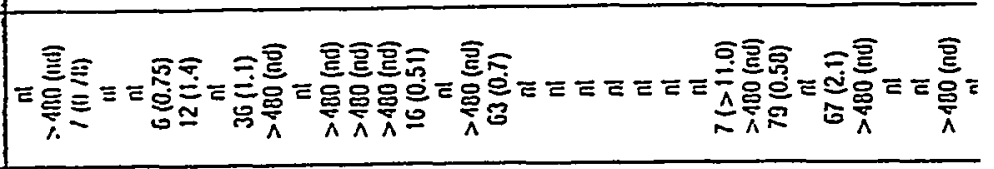 \\
\hline 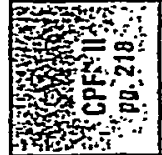 & 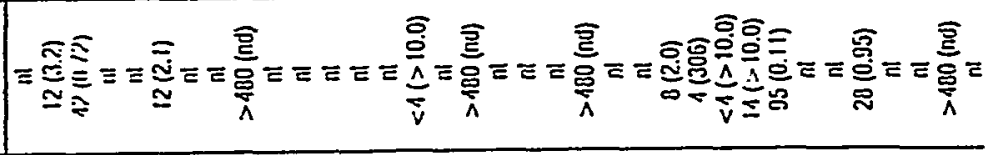 \\
\hline 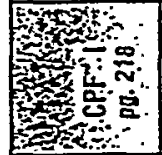 & 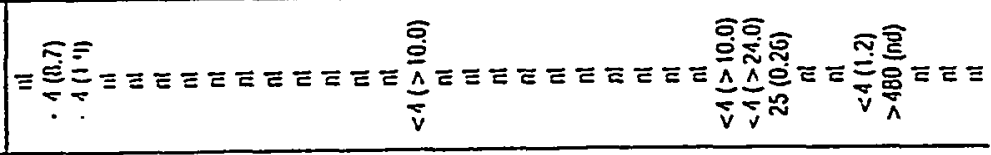 \\
\hline 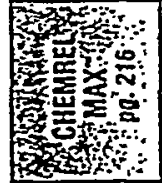 & 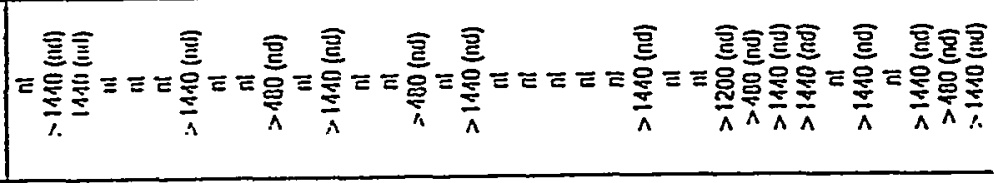 \\
\hline 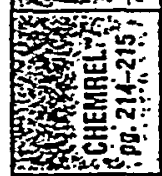 & | \\
\hline 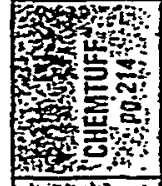 & 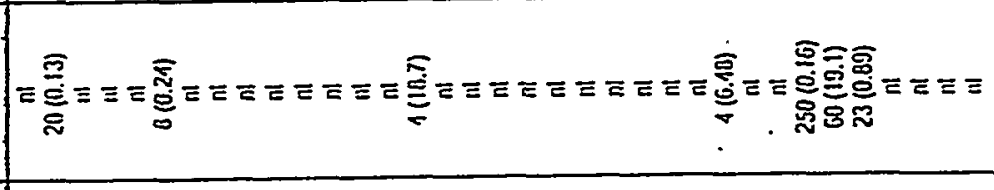 \\
\hline 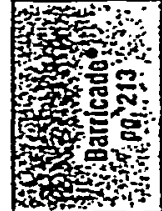 & 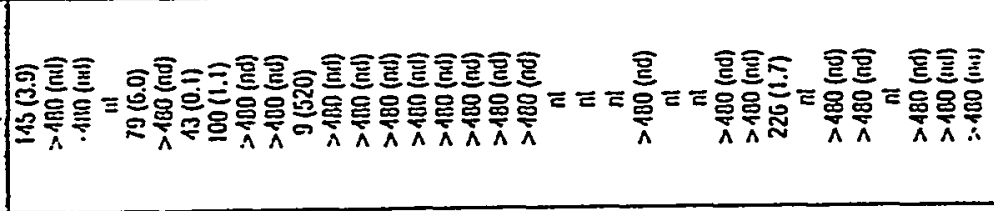 \\
\hline 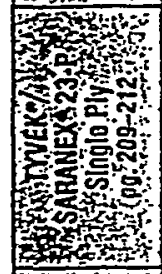 & 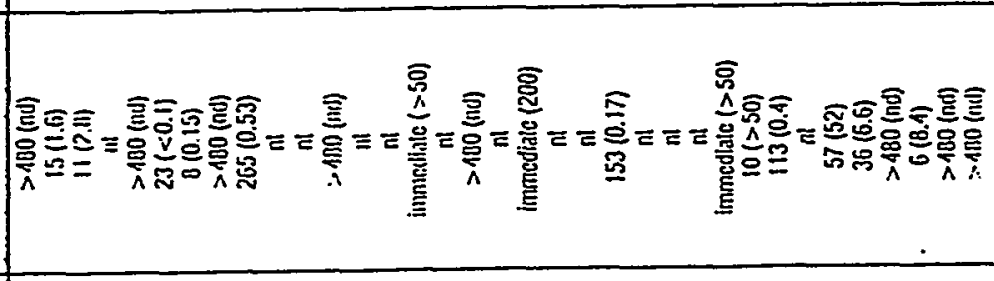 \\
\hline 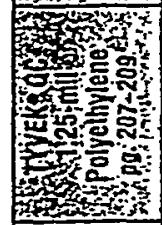 & 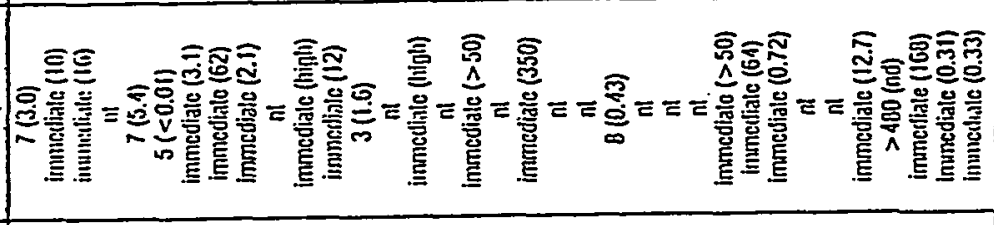 \\
\hline 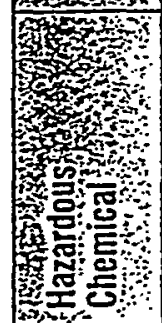 & 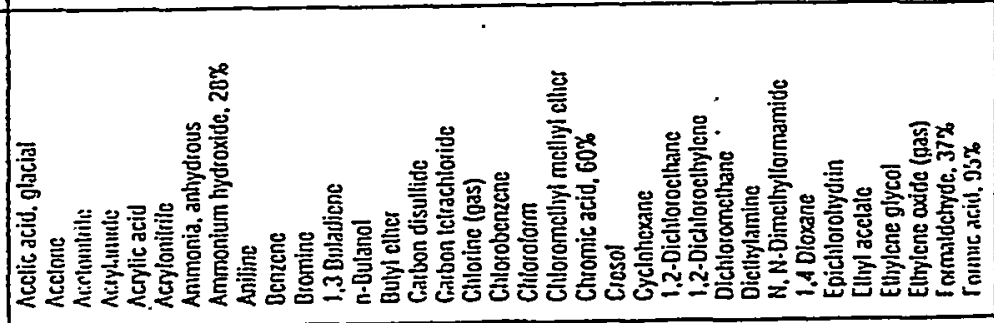 \\
\hline
\end{tabular}




\begin{tabular}{|c|c|c|c|c|c|c|c|c|c|c|c|}
\hline 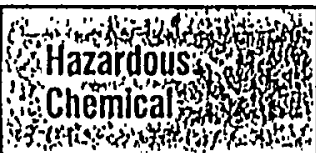 & 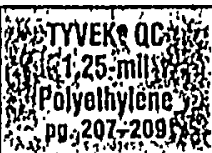 & 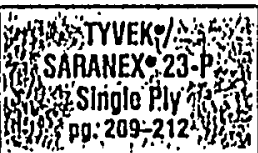 & 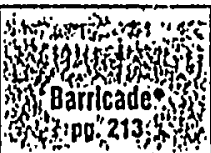 & 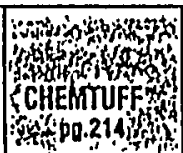 & 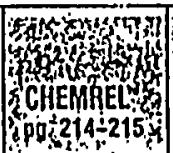 & 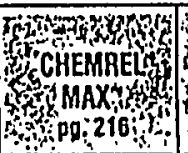 & 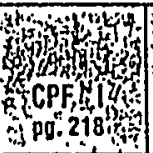 & 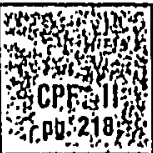 & 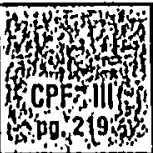 & 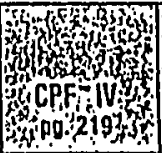 & 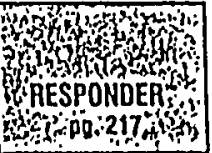 \\
\hline 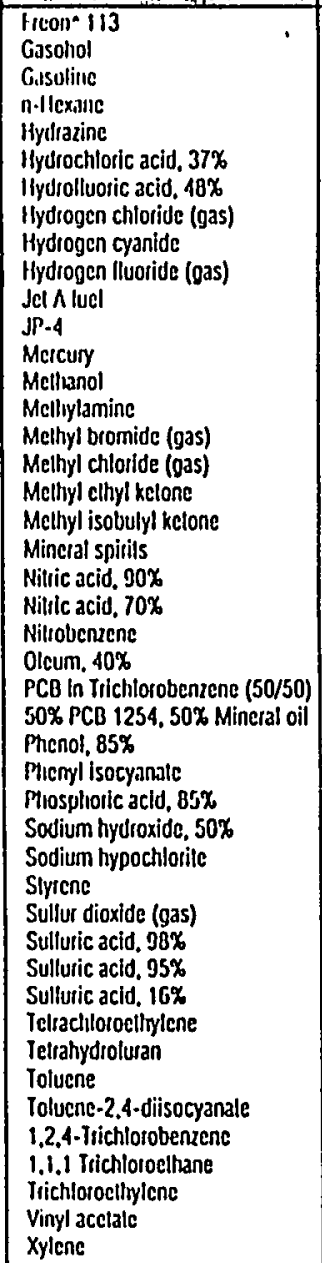 & 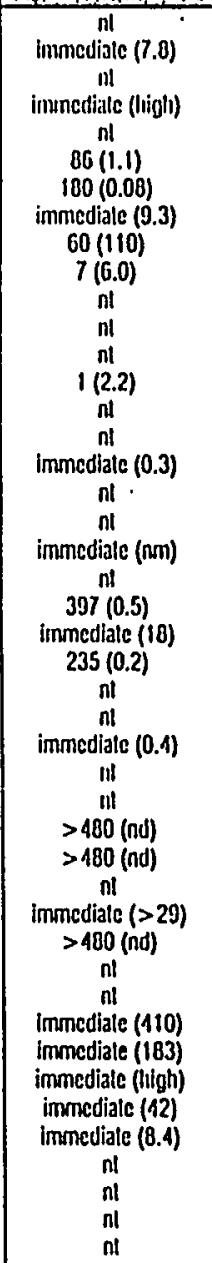 & 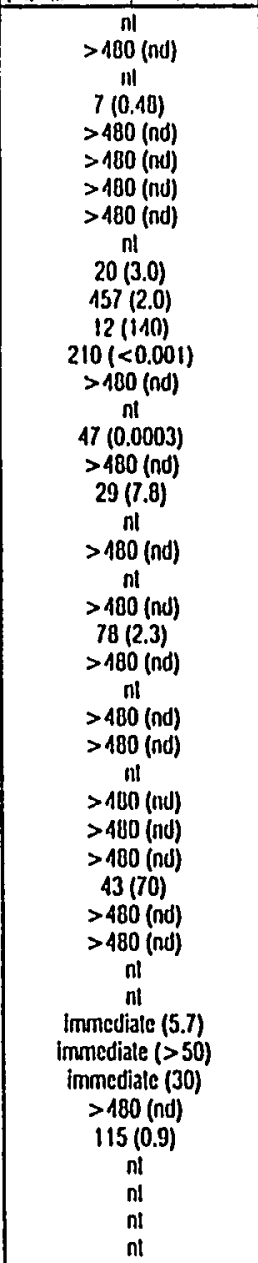 & 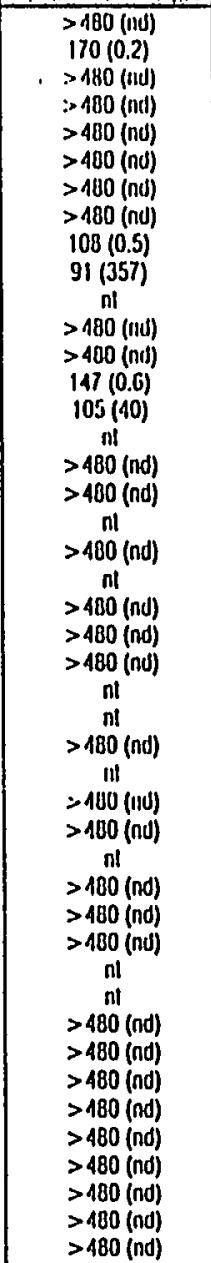 & \begin{tabular}{|c|c|}
$n !$ \\
$n !$ \\
11 \\
$n !$ \\
$n !$ \\
$>180(n d)$ \\
$15(0.03)$ \\
$n !$ \\
$n !$ \\
$n !$ \\
$n !$ \\
$n !$ \\
$n !$ \\
$n !$ \\
$n !$ \\
$n !$ \\
$n !$ \\
$32(0.52)$ \\
$n !$ \\
$n !$ \\
$n !$ \\
$>180(n d)$ \\
$309(0.06)$ \\
$n !$ \\
$n !$ \\
$>480(n d)$ \\
$n !$ \\
$n !$ \\
$>140(n d)$ \\
$n !$ \\
$n !$ \\
$10(23.7)$ \\
$n !$ \\
$n !$ \\
$>400(n d)$ \\
$n !$ \\
$11 !$ \\
$n !$ \\
$n !$ \\
$>180(n d)$ \\
$48(5.77)$ \\
$n !$ \\
$7(4.82)$ \\
$n !$ \\
$n !$ \\
\end{tabular} & 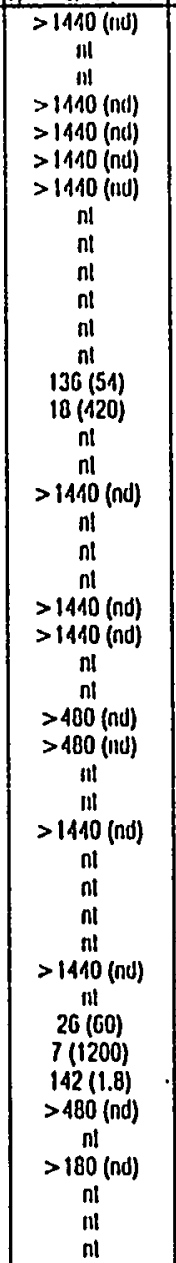 & 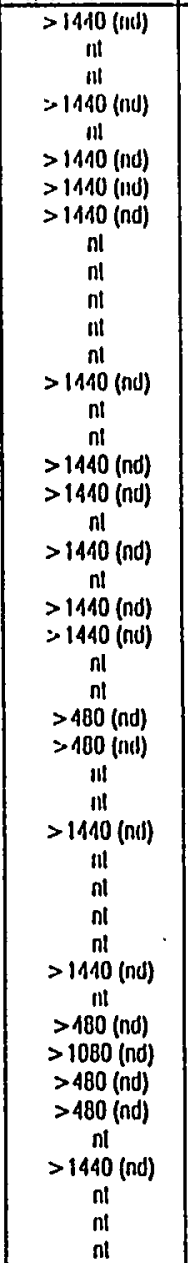 & 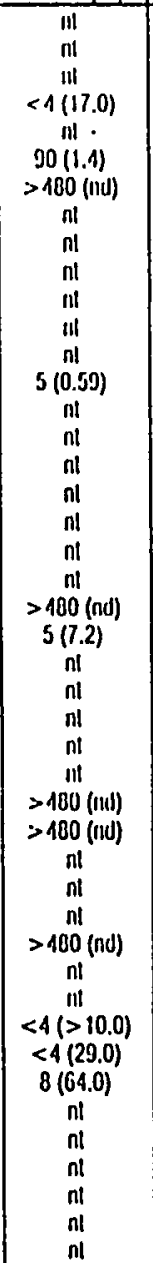 & 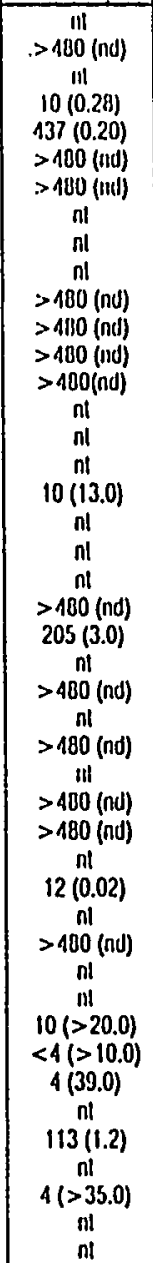 & 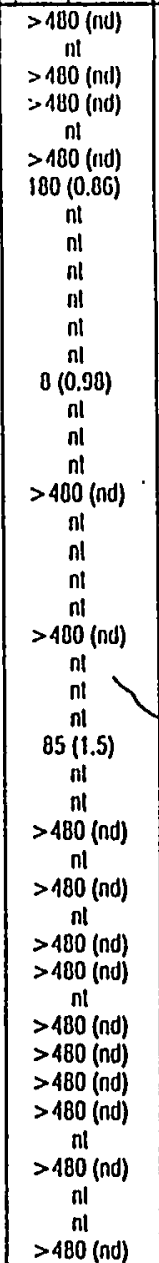 & 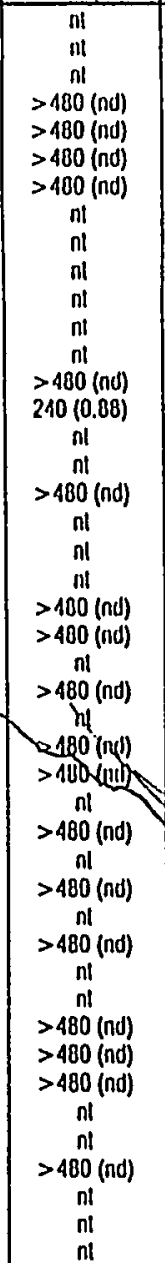 & $\begin{array}{l}>480 \text { (nd) } \\
n ! \\
>480 \text { (nd) } \\
>480 \text { (nd) } \\
>480 \text { (nd) } \\
>240 \text { (nd) } \\
>180 \text { (nd) } \\
>480 \text { (nd) } \\
>180 \text { (nd) } \\
>480 \text { (nd) } \\
n ! \\
>210 \text { (nd) } \\
>480 \text { (nd) } \\
>480 \text { (nd) } \\
>480 \text { (nd) } \\
n ! \\
>480 \text { (nd) } \\
>240 \text { (nd) } \\
>480 \text { (nd) } \\
>480 \text { (nd) } \\
>180 \text { (nd) } \\
>180 \text { (nd) } \\
>480 \text { (nd) } \\
>480 \text { (nd) } \\
n ! \\
n ! \\
>480 \text { (nd) } \\
n ! \\
>480 \text { (nd) } \\
>480 \text { (nd) } \\
>480 \text { (nd) } \\
>180 \text { (nd) } \\
>480 \text { (nd) } \\
n ! \\
>480 \text { (nd) } \\
n ! \\
>480 \text { (nd) } \\
>480 \text { (nd) } \\
>480 \text { (nd) } \\
>480 \text { (nd) } \\
n ! \\
>480 \text { (nd) } \\
>240 \text { (nd) } \\
>180 \text { (nd) } \\
>180 \text { (nd) }\end{array}$ \\
\hline & & 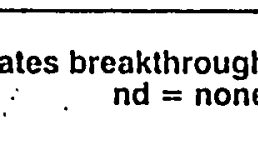 & 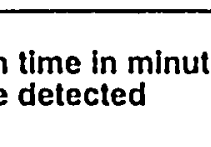 & $\mathrm{nm}=$ & ass & & mas a d a & d & & & \\
\hline \multicolumn{5}{|c|}{ 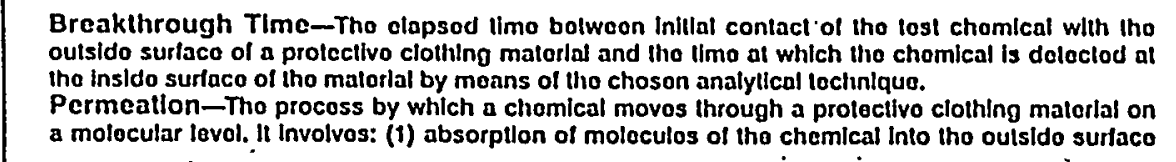 } & \multicolumn{7}{|c|}{ 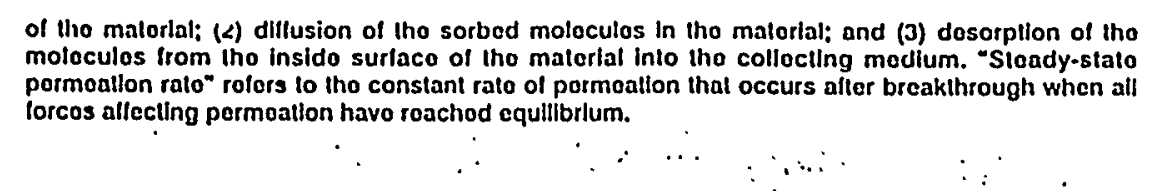 } \\
\hline
\end{tabular}


APPENDIX C: PROPERTIES OF AIRVOL POLYVINYL ALCOHOL (PVA)

C-1 
AIRVOL POLYVINYL

ALCOHOL

TYPICAL PROPERTIES

\begin{tabular}{|c|c|c|c|c|c|c|}
\hline Grade & $\mathrm{Hy}$ & ydrolysis, $\%$ & $\begin{array}{r}\text { Viscosity, cps }{ }^{1} \\
\text { Vat }\end{array}$ & ${ }^{2} \mathrm{pH}^{2}$ & $\begin{array}{c}\text { Volatiles, } \\
\text { \% Max. }\end{array}$ & $\begin{array}{c}\because \text { Ash, }^{2}{ }^{3} \\
\% \text { Max. }^{3}\end{array}$ \\
\hline \multicolumn{7}{|c|}{ Super Hydrolyzed } \\
\hline Ainol 125 & \multicolumn{2}{|r|}{$99.3+$} & $28-32$ & $5.5 \cdot 7.5$ & 5 & 1.0 \\
\hline Airvol 165 & \multicolumn{2}{|r|}{$99.3+$} & $62-72$ & $5.5 \cdot 7.5$ & 5 & 1.0 \\
\hline \multicolumn{7}{|c|}{ Fully Hydrolyzed } \\
\hline Airvol 103 & \multicolumn{2}{|r|}{$98.0-98.8$} & $3.5-4.5$ & $5.0-7.0$ & 5 & 1.0 \\
\hline Aivol 107 & \multicolumn{2}{|r|}{$98.0-98.8$} & $5.5-6.6$ & $5.0-7.0$ & 5 & 1.0 \\
\hline Airvol 321 & \multicolumn{2}{|r|}{$98.0-98.8$} & $16.5-20.5$ & $5.0-7.0$ & 5 & 1.0 \\
\hline Airvol 325 & \multicolumn{2}{|r|}{$98.0-98.8$} & $28.5-32.5$ & $5.0-7.0$ & 5 & 1.0 \\
\hline Airvol 350 & \multicolumn{2}{|r|}{$98.0-98.8$} & 62.72 & $5.0-7.0$ & 5 & 1.0 \\
\hline \multicolumn{7}{|c|}{ Intermediate Hydrolyzed } \\
\hline Airvol WS-42 & \multicolumn{2}{|r|}{$96.5-97.5$} & $14-17$ & $4.5-6.5$ & 5 & 1.0 \\
\hline Airvol 425 & \multicolumn{2}{|r|}{$95.5-96.5$} & $27-31$ & $4.5 \cdot 6.5$ & 5 & 0.7 \\
\hline \multicolumn{7}{|c|}{ Partially Hydrolyzed } \\
\hline Airvol 203 & \multicolumn{2}{|r|}{$87.0-89.0$} & $3.5-4.5$ & $4.5-6.5$ & 5 & 0.7 \\
\hline Airvol 205 & \multicolumn{2}{|r|}{$87.0 \cdot 89.0$} & $5.2-6.2$ & $4.5-6.5$ & 5 & 0.5 \\
\hline Airvol 523 & & $87.0-89.0$ & $23-27$ & $4.0-6.0$ & 5 & 0.3 \\
\hline Ainol 540 & & $87.0-89.0$ & $45-55$ & $4.0-6.0$ & 5 & 0.3 \\
\hline SPECIALTY G & ARADES & $\therefore \quad \therefore \quad \cdots$ & 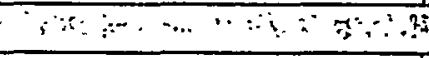 & 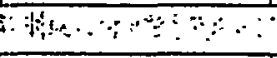 & 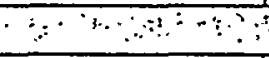 & 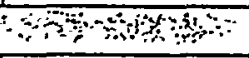 \\
\hline Grade & - $\mathrm{Hy}$ & ydrolysis, \% & Viscosity, cps ${ }^{1}$ & $\mathrm{pH}^{2}$ & $\begin{array}{l}\text { Volatiles, } \\
\% \text { Max. }\end{array}$ & $\begin{array}{c}\text { Ash, } \\
\% \text { Max. }\end{array}$ \\
\hline Polymerization & & & & & & \\
\hline Airvol 805 & & $87.0-89.0$ & $5.2 \cdot 6.2$ & $4.5-6.5$ & 5 & 0.5 \\
\hline Airvol 823 & & $87.0-89.0$ & $23-27$ & $4.0-6.0$ & 5 & 0.3 \\
\hline Airvol 840 & & $87.0-89.0$ & $45-55$ & $4.0-6.0$ & 5 & 0.3 \\
\hline Fine Particle (\$ & S-Grades & & & & & \\
\hline Airvol 2035 & & $87.0-89.0$ & $3.5-4.5$ & $4.5-6.5$ & 5 & 0.7 \\
\hline Airvol 2055 & & $87.0-90.0$ & $5.2-6.2$ & $4.5-6.5$ & 5 & 0.5 \\
\hline Airvol 5235 & & $87.0-90.0$ & $23-27$ & $4.0-6.0$ & 5 & 0.3 \\
\hline Airvol $540 \mathrm{~S}$ & & $87.0-90.0$ & $45-55$ & $4.0-6.0$ & 5 & 0.3 \\
\hline Tackified & & & . & & & \\
\hline Grade & & Viscosity & $\mathrm{cps}^{4}$ & ! & $\mathrm{pH}^{5}$ & \\
\hline Airvol SH-72 & & $3800 \cdot 55$ & $4.4-4$ & & & \\
\hline Airvol SM-73 & & $1200-16$ & $4.4-4$ & & Derived from Sup & \\
\hline Unisize HA-25 & & $35-65$ & $4.0-4$ & & Hydrolyzed Grad & \\
\hline Unisize HA-70 & & $80-155$ & 3.9-4. & & & \\
\hline Airvol MH-82 & & $4200-59$ & 4.4-4. & & & \\
\hline Airvol MM-81 & & $1300-17$ & 4.4-4 & & Derived from Ful & \\
\hline Airvol MM-51 & & $1100-15$ & $4.4-4$ & & Hydrolyzed Grad & \\
\hline Airvol MM-14 & & 245.48 & $4.4-4$ & & & \\
\hline $\begin{array}{l}14 \% \text { aqueous solutio } \\
24 \% \text { aqueous solutio } \\
\text { 'As } \% \mathrm{Na}_{2} \mathrm{O} \text {, correct }\end{array}$ & $\begin{array}{l}n, 20^{\circ} \mathrm{C} . \\
n . \\
\text { ed volatiles }\end{array}$ & & $\begin{array}{l}10 \% \text { aqueous solution, } 25^{\circ} \mathrm{C} \text {. } \\
10 \% \text { aqueous solution. } \\
5 \% \text { solution, } 25^{\circ} \mathrm{C} \text {. }\end{array}$ & $\begin{array}{l}? 5 \% \text { a } \\
\text { U Use } \\
\text { is cove }\end{array}$ & $\begin{array}{l}\text { queous slurry. } \\
\text { of Airvol } 203 \text { Solyvinyl a } \\
\text { ered by US. Palent No. } 5\end{array}$ & $\begin{array}{l}\text { lcohol } \\
, 057,570\end{array}$ \\
\hline
\end{tabular}




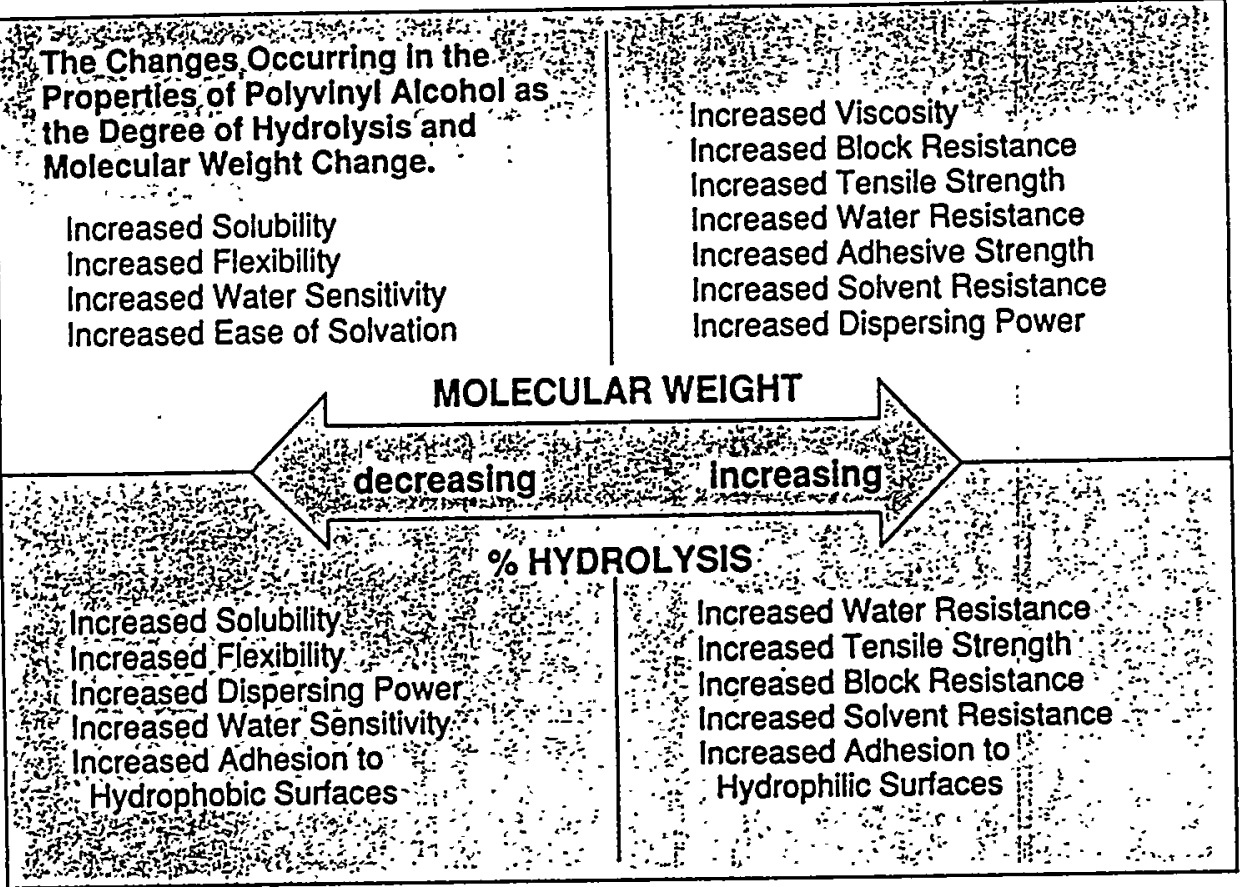

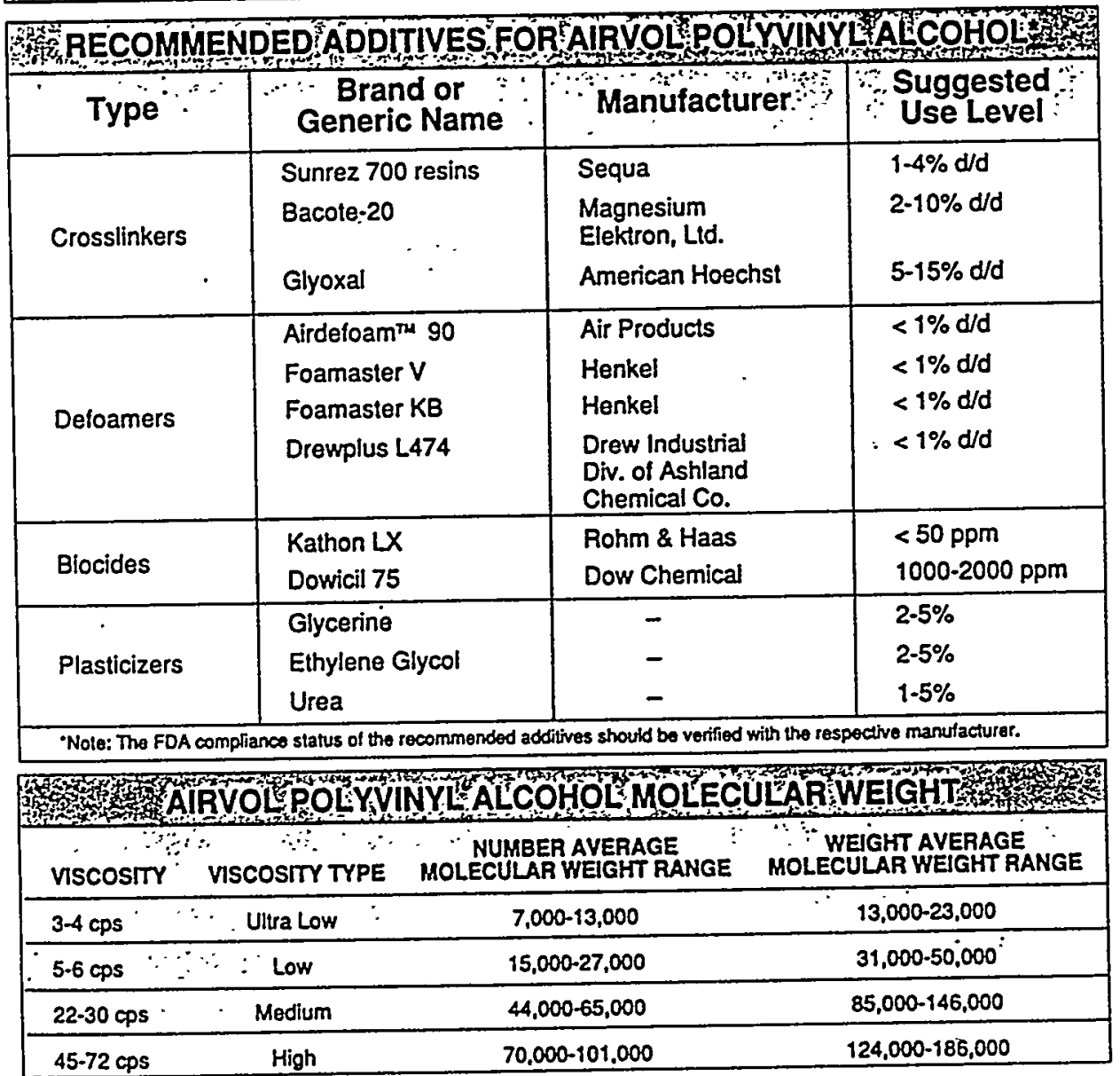

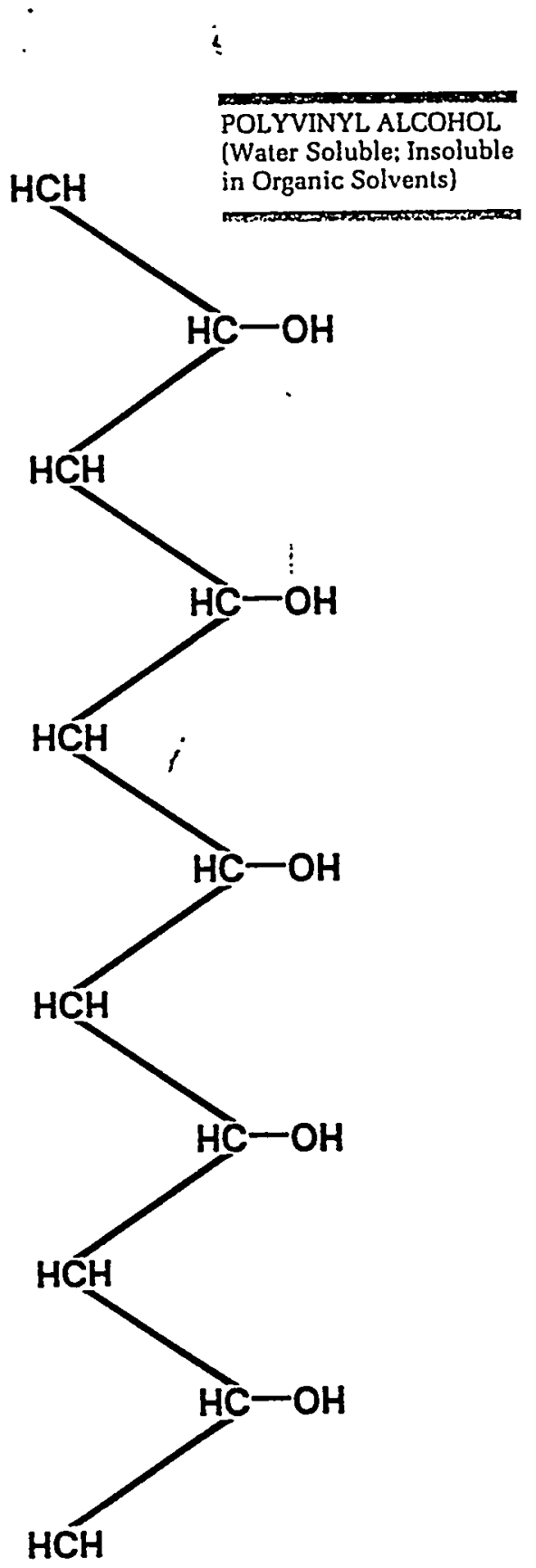

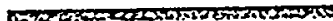

Molecular weight aver-

ages for ultra low, low. medium and high viscosity polyvinyl alcohols. 
APPENDIX D: $\quad$ SEMS FOR FABRICS PREPARED WITH VARIOUS POLYVINYL ALCOHOL (PVA) SELECTIVE LAYERS

D-1 


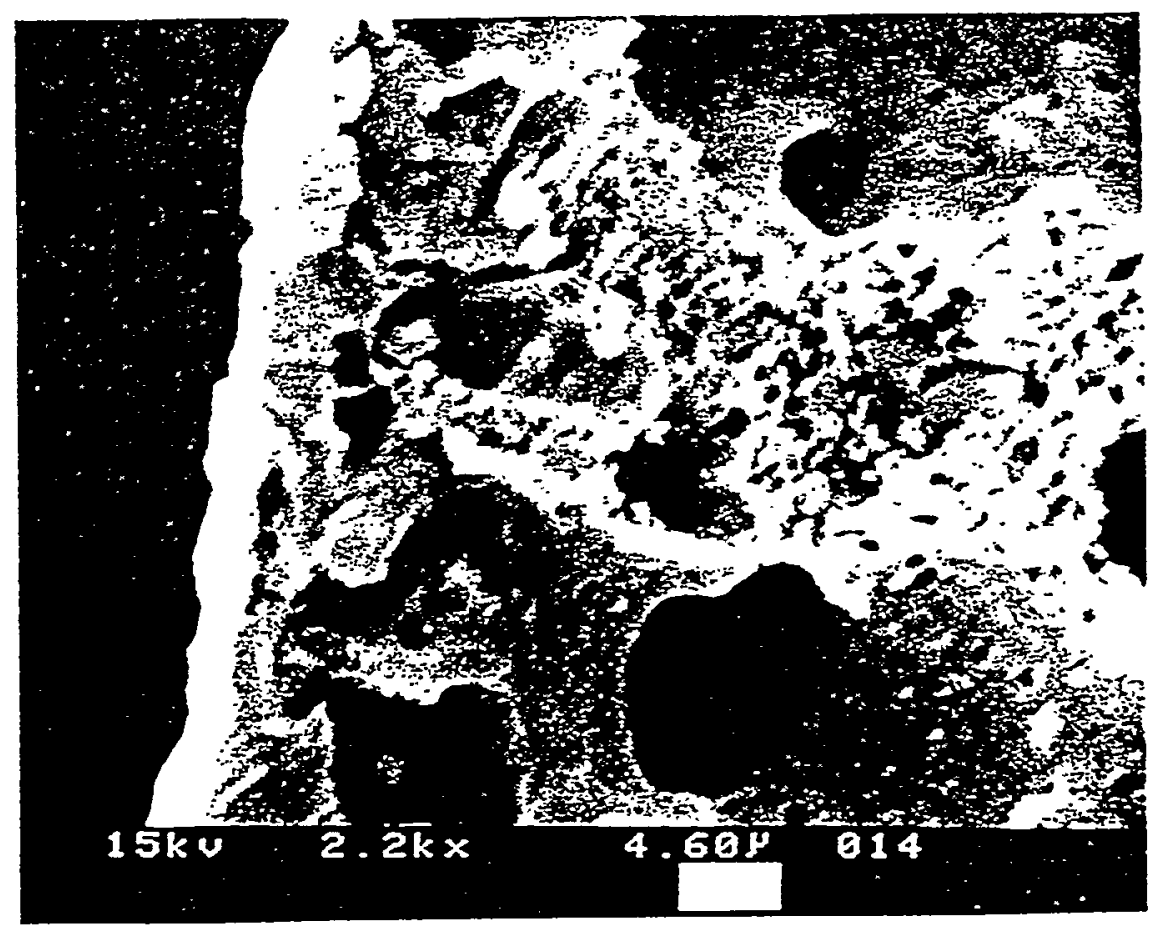

Figure D1. SEM of $3 \%$ PVA on Kynar 761: carbon sorbent layer with $6 \%$ silicone rubber overcoat. The PVA layer is non-continuous.

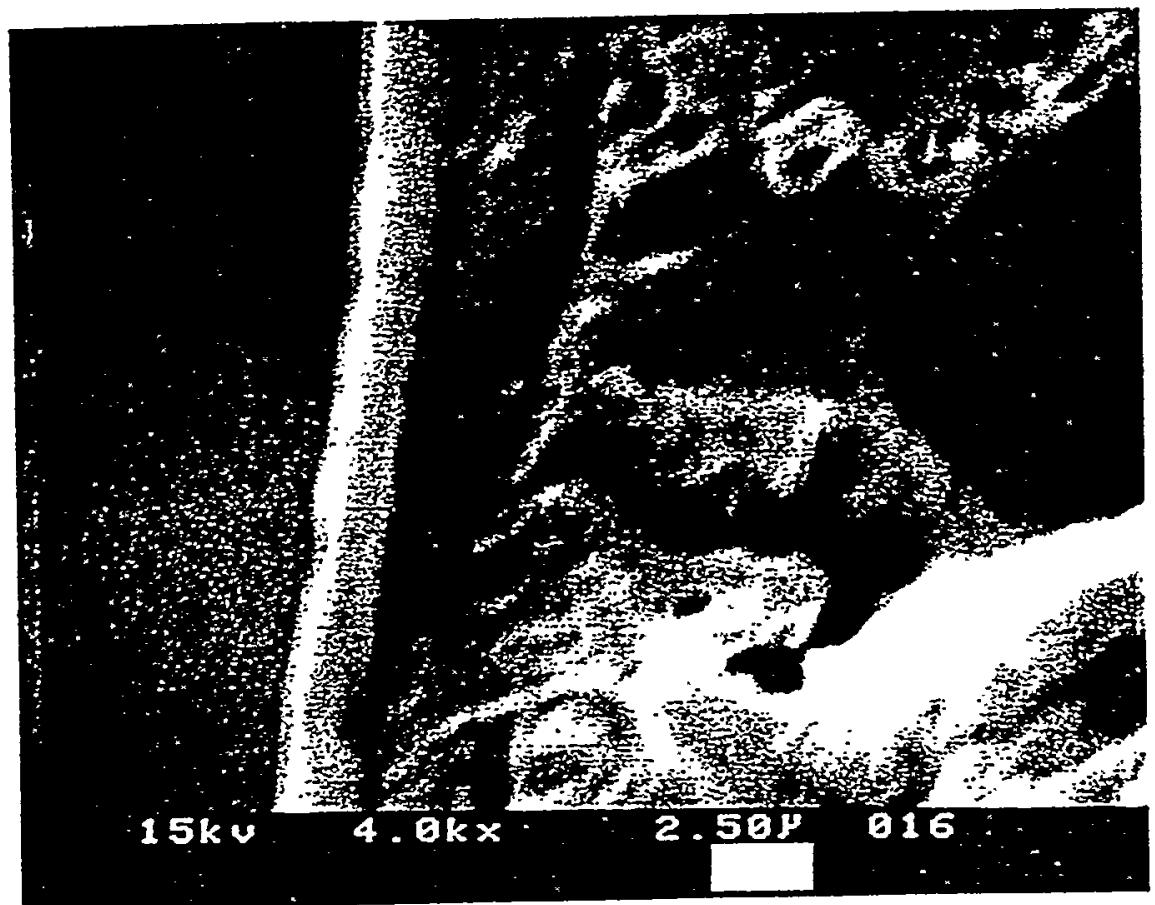

Figure D2. SEM of $5 \%$ PVA on Kynar 761: carbon sorbent layer with $6 \%$ silicone rubber overcoat. PVA layer thickness $\sim 2.5 \mu \mathrm{m}$. 


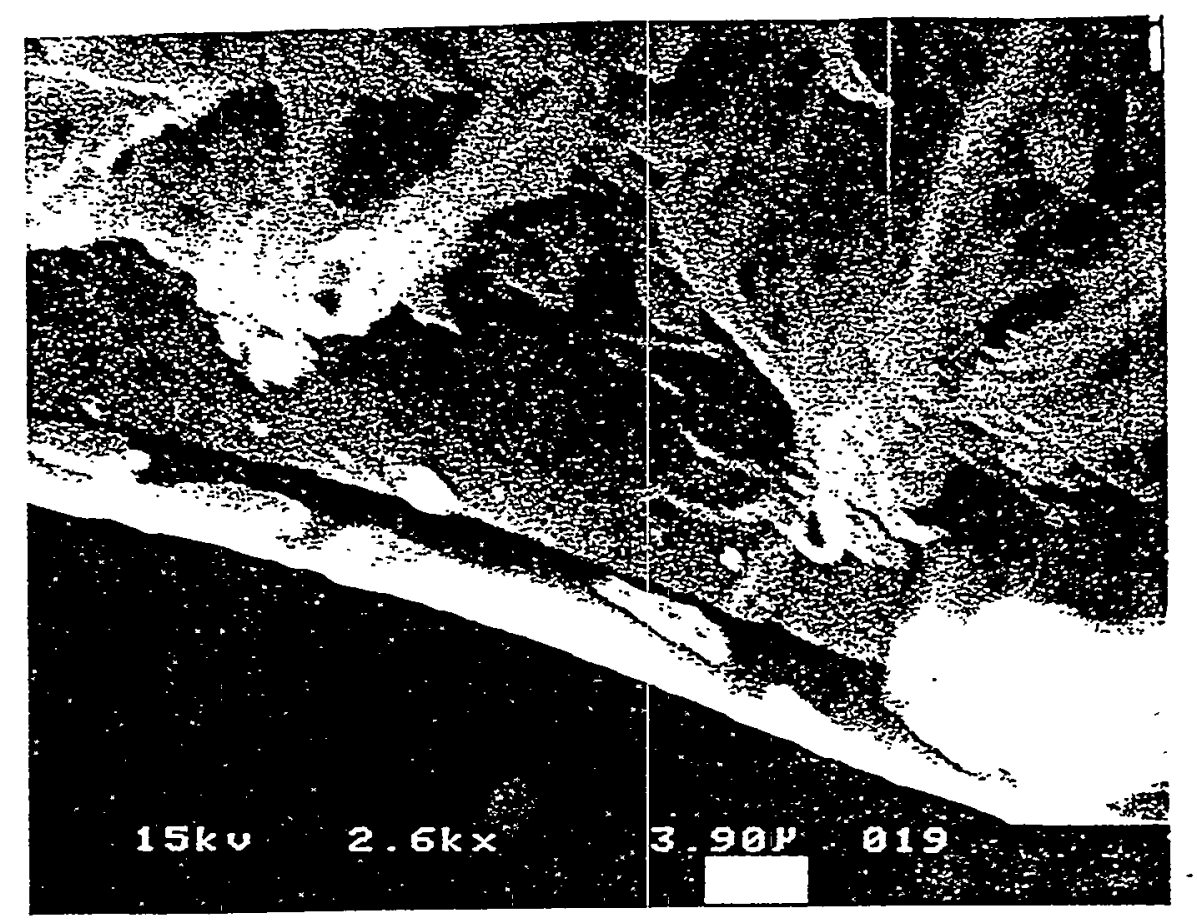

Figure D3. SEM of double 5\% PVA on Kynar 761: carbon sorbent layer with $6 \%$ silicone rubber overcoat. PVA layer thickness is $\sim 8 \mu \mathrm{m}$.

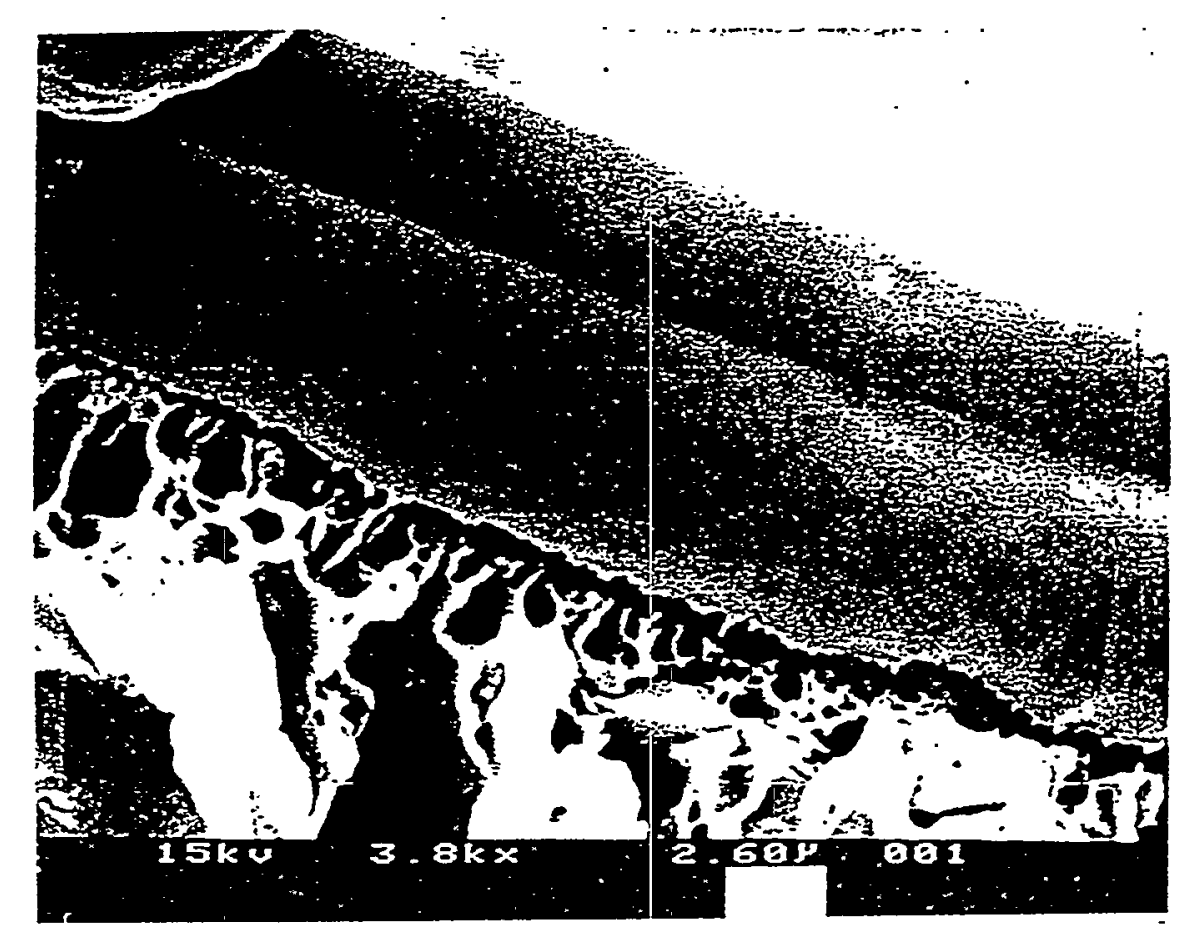

Figure D4. SEM of $8 \%$ PVA on Kynar 761: carbon sorbent layer with $6 \%$ silicone rubber overcoat. PVA layer thickness $\sim 7 \mu \mathrm{m}$. 
APPENDIX E: FABRIC TEST REPORTS

E-1 


\section{PERMEATION TEST REPORT}

ASTM F 739-91 (NORMALIZED)
MATERIAL NAME:
MTR-1
CHALLENGE CHEMICAL:
DICHLOROMETHANE
FABRIC LOG OR LOT NO.:
MANUFACTURER:
MTR
RUN NO:
PERM4L280

\begin{tabular}{|c|c|c|c|c|}
\hline TEST RESULTS & TEST 1I & TEST 2 & TEST 3 & AVERAGE \\
\hline NORMALIZED (0.1 UG/SQ CM/MIN) & 11 & 11 & 1) & 1 \\
\hline BREAKTHROUGH TIME, MIN & & & & \\
\hline PERMEATION RATE STEADY & 497 & 393 & 432 & 441 \\
\hline STATE MAXIMUM, UG/SQ CM/MIN & & & & \\
\hline THICKNESS, MILS & 10 & 10 & 10 & 10 \\
\hline WEIGHT, OZISQ YD & 5.57 & 5.70 & 5.84 & 5.70 \\
\hline
\end{tabular}

TEST DATE:

PRIOR CONDITIONING:

CAS NO:

CHEMICAL SOURCE:

CONCENTRATION:

SAMPLING FREOUENCY:

MINIMUM DETECTION LIMIT:

MINIMUM DETECTABLE RATE:

TEMPERATURE:

TEST DURATION:

METHOD MODIFICATION:

SPECIMEN AREA EXPOSED:

1-16-96
NONE
$75-09-2$
ALDRICH
$100 \%$
$6 \mathrm{MIN}$
0.16 PPM
0.056 UG/SQ CMMIN
22 OC
O HOURS
NONE
20.3 SQ. CM

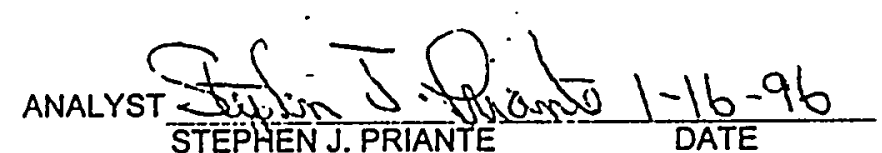

ANALYTICAL METHOD: COLLECTION SYSTEM: COLLECTION MEDIUM VOLUME: CHEMICAL STATE: CHEMICAL CONTACT TYPE COLLECTION MEDIUM: POST TEST CONDITON:

CLIENT:

MEMBRANE TECHNOLOGY \& RESEARCH

CONTACT:
INFRARED OPEN LOOP

NA

LIQUID CONTINUOUS NITROGEN SLIGHT EXPANSION

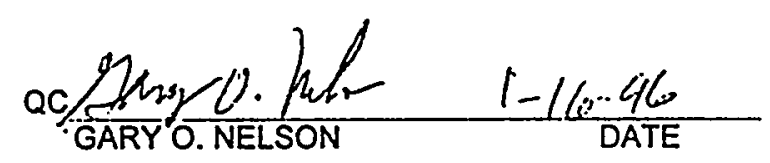

This data is derived from tests performed in accordance with ASTM F739-91. These tests were performed under laboratory conditions and not under aclual usage conditions. Miller-Nelson Research Inc. makes no warranties concerning protection by this material and assumes no liability for use of this material with the chemicals tested. The user should delermine the applicability of the conditions when assessing suitability of material for actual anticipated exposure. 


\section{PERMEATION TEST REPORT}

ASTM F 739-91 (NORMALIZED)

MATERIAL NAME:

MTR-2

CHALLENGE CHEMICAL:

DICHLOROMETHANE

FABRIC LOG OR LOT NO:

MANUFACTURER:

MTR

RUN NO:

PERM41281

\begin{tabular}{|c|c|c|c|c|}
\hline TEST RESULTS & IEST 1I & TEST 2 & TEST 3. & AVERAGE \\
\hline NORMALIZED (0.1 UG/SQ CM/MIN) & 1 & 11 & 11 & 1 \\
\hline \multicolumn{5}{|l|}{ BREAKTHROUGH TIME, MIN } \\
\hline PERMEATION RATE STEADY & 1571 & 174 & 160 & 164 \\
\hline \multicolumn{5}{|l|}{ STATE MAXIMUM, UG/SQ CM/MIN } \\
\hline THICKNESS, MILS & 8 & 81 & 8 & 8 \\
\hline WEIGHT, OZISQ YD & 6.05 & 6.09 & 6.25 & 6.13 \\
\hline
\end{tabular}

TEST DATE:

PRIOR CONDITIONING:

CAS NO:

CHEMICAL SOURCE:

CONCENTRATION:

SAMPLING FREQUENCY:

MINIMUM DETECTION LIMIT:

MINIMUM DETECTABLE RATE:

TEMPERATURE:

TEST DURATION:

METHOD MODIFICATION:

SPECIMEN AREA EXPOSED:

$1-16-96$
NONE
$75-09-2$
ALDRICH
$100 \%$
$6 \mathrm{MIN}$
$0.16 \mathrm{PPM}$
0.056 UG/SQ CMIMIN
22 OC
1 HOURS
NONE
20.3 SQ. CM

$20.3 \mathrm{SQ} . \mathrm{CM}$

\begin{abstract}
ANALYTICAL METHOD:
COLLECTION SYSTEM:

COLLECTION MEDIUM VOLUME:

CHEMICAL STATE:

CHEMICAL CONTACT TYPE CONTINUOUS

COLLECTION MEDIUM:

POST TEST CONDITON:

NITROGEN

NO CHANGE

INFRARED

OPEN LOOP

NA

LIQUID
\end{abstract}

CLIENT: $\quad$ MEMBRANE TECHNOLOGY \& RESEARCH

CONTACT: $\quad$ DOUG GOTTSCHLICH

This data is derived from tests performed in accordance with ASTM F739-91. These tests were performed under laboratory conditions and not under actual usage conditions. Miller-Nelson Research Inc. makes no warranties concerning protection by this material and assumes no liability for use of this material with the chemicals tested. The user should determine the applicability of the conditions when assessing suitability of material for actual anticipated exposure. 
PERMEATION TEST REPORT

ASTM F 739-91 (NORMALIZED)

MATERIAL NAME:

SARAN

CHALLENGE CHEMICAL:

DICHLOROMETHANE

FABRIC LOG OR LOT NO.:

MANUFACTURER:

MTR

RUN NO:

PERM41279

\begin{tabular}{|c|c|c|c|c|}
\hline TESTRESULTS & TEST 1 & TEST 2 & TEST 3 & AVERAGE \\
\hline NORMALIZED (0.1 UG/SQ CM/MIN) & $4 !$ & 4) & $4 \mid$ & 4 \\
\hline \multicolumn{5}{|l|}{ BREAKTHROUGH TIME, MIN } \\
\hline PERMEATION RATE STEADY & 118 & 109 & 129 & 119 \\
\hline \multicolumn{5}{|l|}{ STATE MAXIMUM, UG/SQ CM/MIN } \\
\hline THICKNESS, MILS & 9 & 9 & 10 & 9 \\
\hline WEIGHT, OZISQ YD & 3.61 & 3.65 & 3.60 & 3.62 \\
\hline
\end{tabular}

TEST DATE:

PRIOR CONDITIONING:

CASNO:

CHEMICAL SOURCE:

CONCENTRATION:

SAMPLING FREQUENCY:

MINIMUM DETECTION LIMIT:

MINIMUM DETECTABLE RATE:

TEMPERATURE:

TEST DURATION:

METHOD MODIFICATION:

SPECIMEN AREA EXPOSED:

1-16-96
NONE
$75-09-2$
ALDRICH
$100 \%$
3 MIN
0.16 PPM
0.056 UG/SQ CNMIN
22 OC
1 HOURS
NONE
20.3 SQ. CM

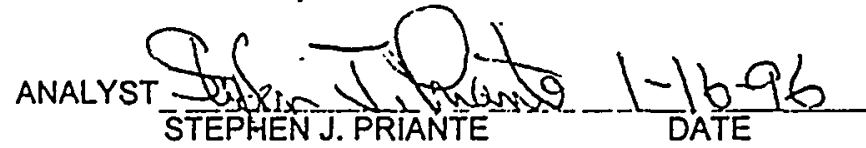

ANALYTICAL METHOD:

COLLECTION SYSTEM:

COLLECTION MEDIUM VOLUME:

CHEMICAL STATE:

CHEMICAL CONTACT TYPE

COLLECTION MEDIUM:

POST TEST CONDITON:

CLIENT:

MEMBRANE TECHNOLOGY \& RESEARCH

CONTACT:
INFRARED

OPEN LOOP

NA

LIQUID

CONTINUOUS

NITROGEN

SLIGHT EXPANSION DOUG GOTTSCHLICH

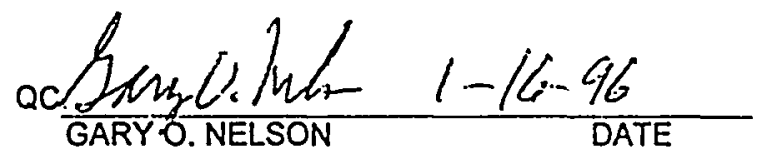

This data is derived from tests performed in accordance with ASTM F739-91. These tests were performed under laboratory conditions and not under actual usage conditions. Miller-Nelson Research inc. makes no wartanties concerning protection by this material and assumes no liability for use of this material with the chemicals tested. The user should determine the applicability of the conditions when assessing suitability of material for actual anticipated exposure. 
TRI/Environmental, Inc. 9063 Bee Caves Road

Austin, TX 78733

$\mathrm{PH}$ 800-880-8378

FX 5122632558

Membrane Technology \& Research 1360 Willow Road

Menlo Park, CA 94025
Filename: $\quad$ WTO08TO4

Standard: $\quad$ ASTM E96-94(Inverted)

Material Log \#: 96008-128-16

Test Dates: $\quad 3 / 4 / 96$

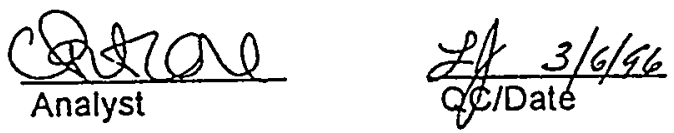

\section{WATER VAPOR TRANSMISSION TEST REPORT}

Material Name:

Diameter of Sample:

Area of Sample:
MTR - 2

6.25 Centimeters

0.00317 Square Meters

\begin{tabular}{|c|c|c|c|c|c||}
\hline $\begin{array}{c}\text { Time } \\
\text { (Hours) }\end{array}$ & $\begin{array}{c}\text { Cell 1 } \\
\text { Weight }\end{array}$ & $\begin{array}{c}\text { Cell 2 } \\
\text { Weight }\end{array}$ & $\begin{array}{c}\text { Cell 3 } \\
\text { Weight }\end{array}$ & $\begin{array}{l}\text { Averag } \\
\text { Weight }\end{array}$ & $\begin{array}{c}\text { Average } \\
\text { Weight Loss }\end{array}$ \\
\hline \hline 0 & 127.50 & 128.30 & 128.03 & 127.94 & 0.00 \\
\hline 2 & 127.29 & 128.08 & 127.76 & 127.71 & -0.23 \\
\hline 3 & 127.04 & 127.85 & 127.53 & 127.47 & -0.47 \\
\hline 4 & 126.86 & 127.68 & 127.34 & 127.29 & -0.65 \\
\hline 5 & 126.69 & 127.43 & 127.11 & 127.08 & -0.87 \\
\hline 6 & 126.58 & 127.33 & 126.98 & 126.96 & -0.98 \\
\hline
\end{tabular}

Weight in Grams

Water Vapor Transmission Rate: $\quad 54.39 \mathrm{~g} / \mathrm{h} / \mathrm{m}^{\wedge} 2$

Comments: See attached graph

These data are derived from tests periomed in accordance with ASTM Standard E 96-94. These tests were performed under laboratory conditions and not under actual usage conditions. TR! Emvironmental, Inc. makes no wartanties or other guaranteos concerning protection by this material and assume no liability for use of this material. The uses should determine the applicability of lest conditions when assessing suitability of material for actual anticipated exposure. 


\section{Average Weight Loss \\ MTR- 2 (Inverted)}

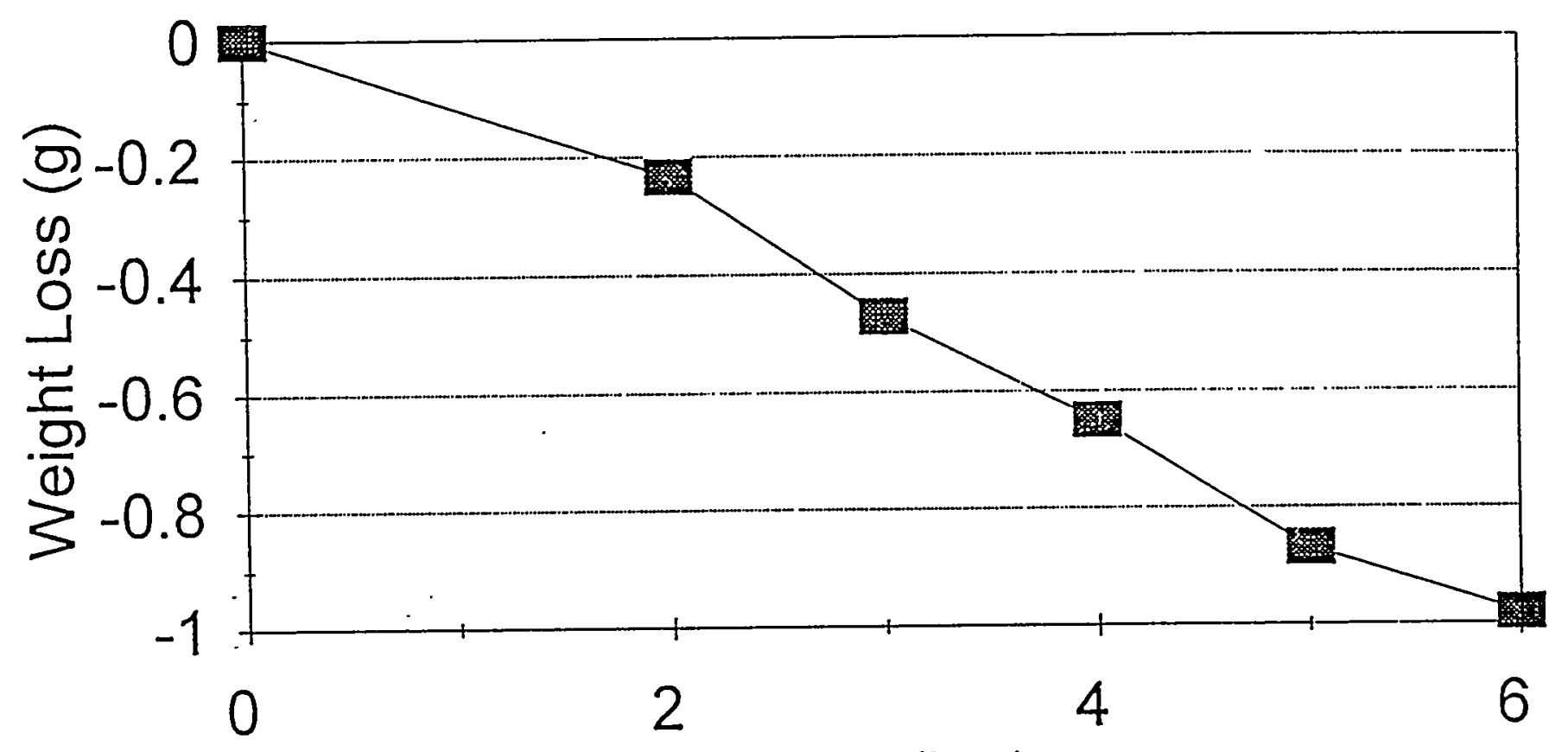

Time (hrs) 
TRI/Environmental, Inc.

9063 Bee Caves Road

Austin, TX 78733

PH $800-880-8378$

FX 5122632558

Membrane Technology \& Research

1360 Willow Road

Menlo Park, CA 94025
Filename: $\quad$ WT008T03

Standard: $\quad$ ASTM E96-94

Material Log \#: 96008-128-16

Test Dates: $\quad 3 / 4 / 96$

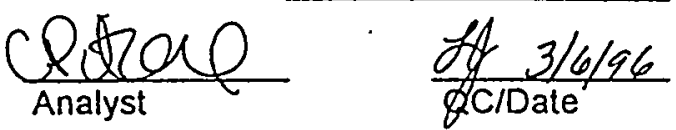

\section{WATER VAPOR TRANSMISSION TEST REPORT}

Material Name:

MTR - 2

Diameter of Sample:

6.25 Centimeters

Arta of Sample:

0.00317 Square Meters

\begin{tabular}{|c||c|c|c|c|c||}
\hline $\begin{array}{c}\text { Time } \\
\text { (Hours) }\end{array}$ & $\begin{array}{c}\text { Cell 1 } \\
\text { Weight }\end{array}$ & $\begin{array}{c}\text { Cell 2 } \\
\text { Weight }\end{array}$ & $\begin{array}{c}\text { Cell 3 } \\
\text { Weight }\end{array}$ & $\begin{array}{l}\text { Averag } \\
\text { Weight }\end{array}$ & $\begin{array}{c}\text { Average } \\
\text { Weight Loss }\end{array}$ \\
\hline 0 & 127.95 & 128.46 & 128.12 & 128.18 & 0.00 \\
\hline 2 & 127.78 & 128.28 & 127.92 & 127.99 & -0.18 \\
\hline 3 & 127.67 & 128.08 & 127.70 & 127.82 & -0.36 \\
\hline 4 & 127.59 & 127.94 & 127.59 & 127.71 & -0.47 \\
\hline 5 & 127.48 & 127.81 & 127.52 & 127.60 & -0.57 \\
\hline 6 & 127.40 & 127.70 & 127.45 & 127.52 & -0.66 \\
\hline
\end{tabular}

Weight in Grams

Water Vapor Transmission Rate: $\quad 36.02 \mathrm{~g} / \mathrm{h} / \mathrm{m}^{\wedge} 2$

Comments: See aftached graph

These data aro derived from tests performed in accordance with ASTM Standard E 06-94. These tests were performed under laboratory conditions and not under actual usage conditions. TRI Environmental, inc. makes no warranties or other guarantees concerning prolection by this material and assume no liability for use of this malorial. The user should delermine the applicability of test conditions when assessing suilability of material for actual anticipated exposure. 
Average Weight Loss MTR- 2

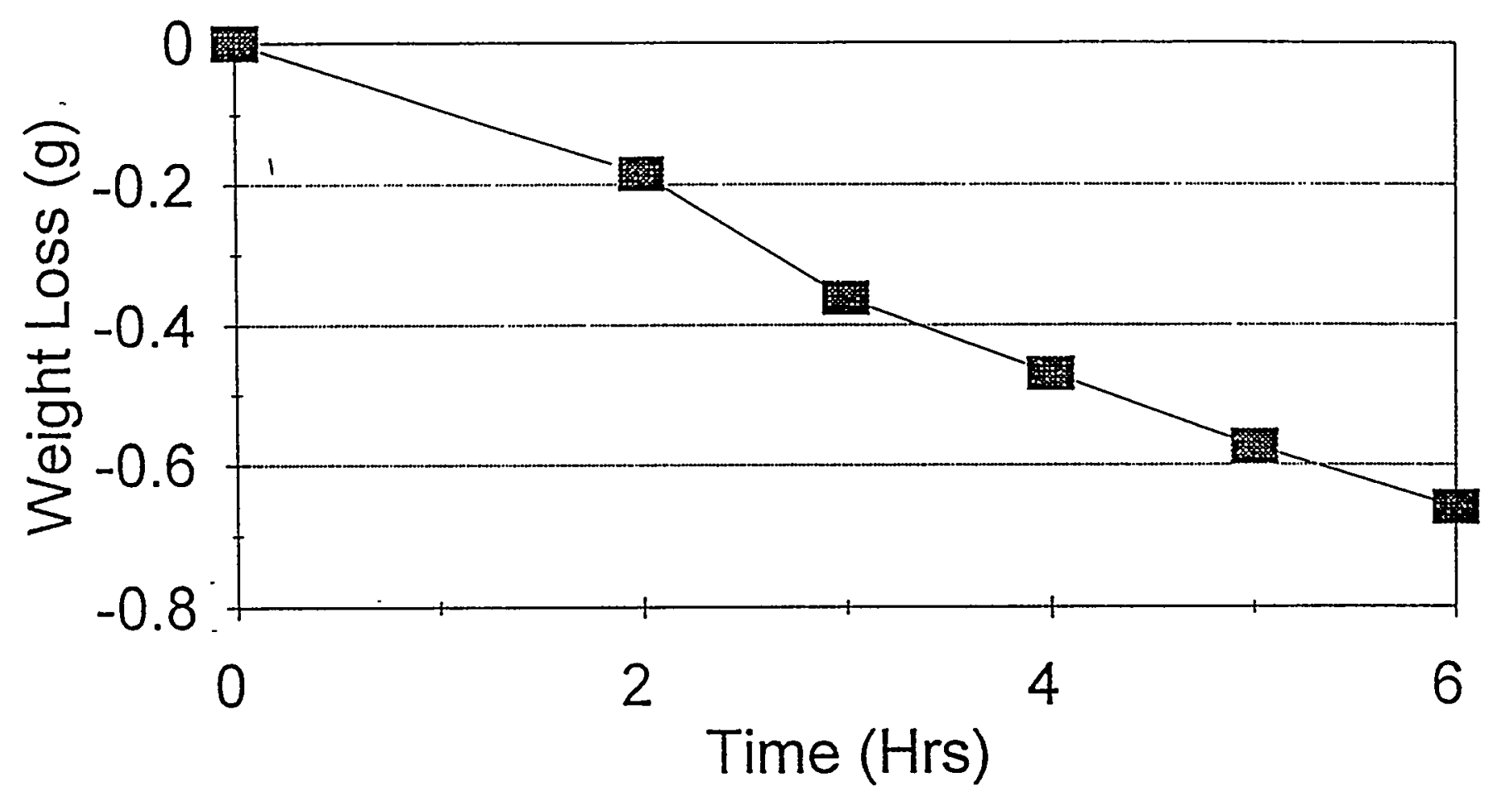


TRl/Environmental, Inc. 9063 Bee Caves Road Austin, TX 78733

PH 800-880-8378

FX 5122632558

Membrane Technology \& Research 1360 Willow Road

Menlo Park, CA 94025
Filename: $\quad$ WT008T01

Standard: $\quad$ ASTM E96-94(Inverted)

Material Log \#: 96008-128-15

Test Dates: $\quad 3 / 4 / 96$

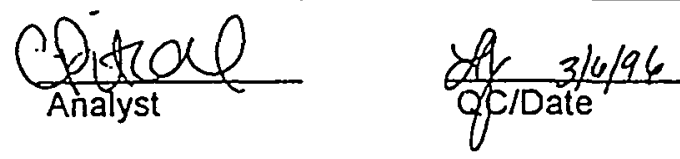

\section{WATER VAPOR TRANSMISSION TEST REPORT}

Material Name:

Diameter of Sample:

Area of Sample:
MTR - 1

6.25 Centimeters

0.00317 Square Meters

\begin{tabular}{|c|c|c|c|c|c||}
\hline $\begin{array}{c}\text { Time } \\
\text { (Hours) }\end{array}$ & $\begin{array}{c}\text { Cell 1 } \\
\text { Weight }\end{array}$ & $\begin{array}{c}\text { Cell 2 } \\
\text { Weight }\end{array}$ & $\begin{array}{c}\text { Cell 3 } \\
\text { Weight }\end{array}$ & $\begin{array}{l}\text { Averag } \\
\text { Weight }\end{array}$ & $\begin{array}{c}\text { Average } \\
\text { Weight Loss }\end{array}$ \\
\hline 0 & 128.78 & 128.44 & 128.23 & 128.48 & 0.00 \\
\hline 2 & 128.48 & 128.20 & 128.00 & 128.23 & -0.26 \\
\hline 3 & 128.28 & 128.01 & 127.82 & 128.04 & -0.45 \\
\hline 4 & 128.10 & 127.86 & 127.66 & 127.87 & -0.61 \\
\hline 5 & 127.90 & 127.69 & 127.47 & 127.69 & -0.80 \\
\hline 6 & 127.81 & 127.60 & 127.40 & 127.60 & -0.88 \\
\hline
\end{tabular}

Weight in Grams

Water Vapor Transmission Rate:

\section{$48.54 \mathrm{~g} / \mathrm{h} / \mathrm{m}^{\wedge} 2$}

Comments: See attached graph

\footnotetext{
These data are derived from tests performed in accordance with ASTM Standard E 86-94. These tests wete performed under laboratory conditions and not under actual usage conditions. TRI Envitonmental, Ine. makes no warranties or other guarantees concerning protection by this malerial and assume no liability for use of this material. The user should determine the applicability of test conditions when assessing suitability of material for actual anticipated
} exposure. 


\section{Average Weight Loss MTR- 1 (Inverted)}

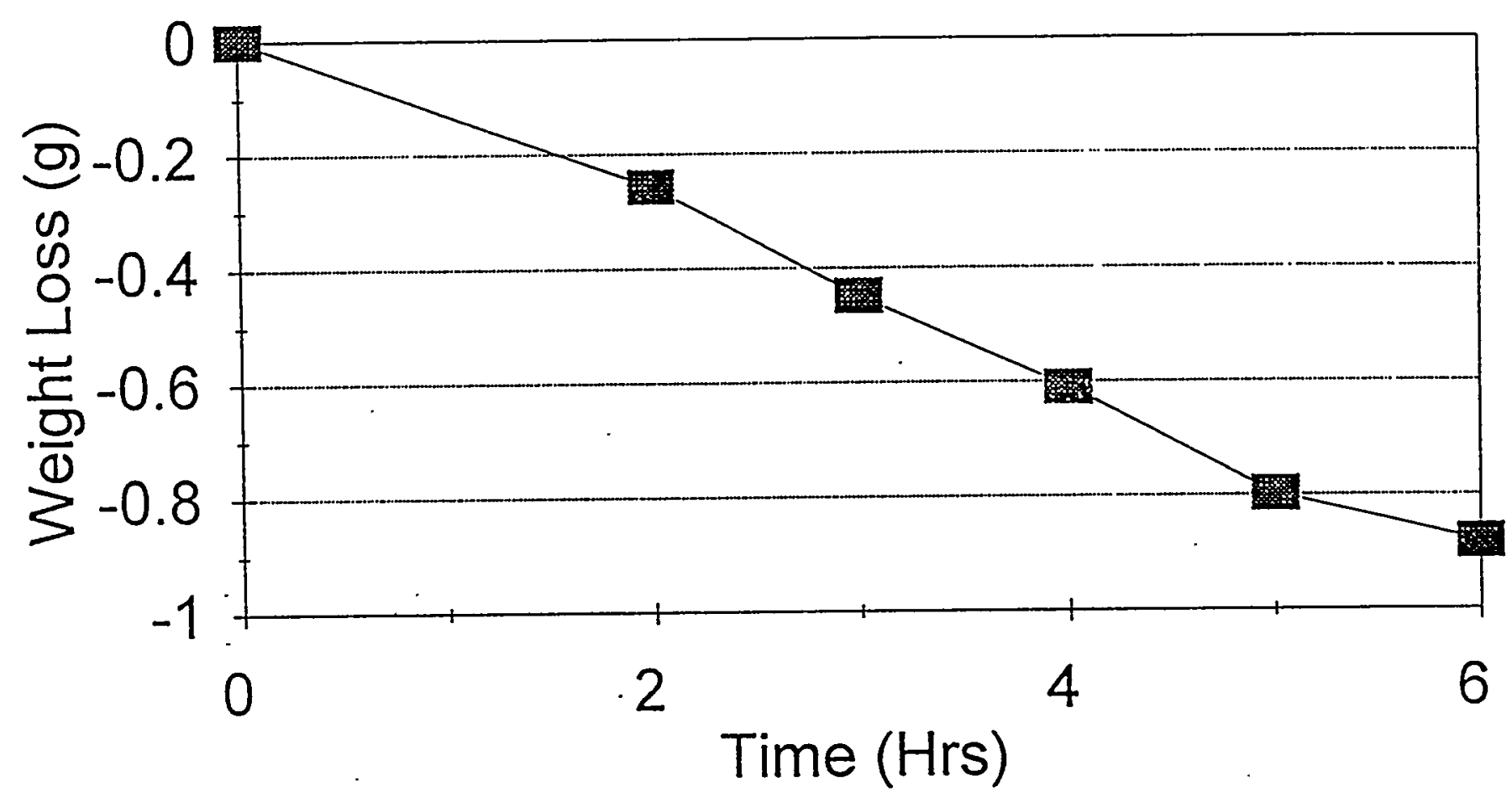


TRI/Environmental, Inc.

9063 Bee Caves Road

Austin, TX 78733

PH $800-880-8378$

FX 5122632558

Membrane Technology \& Research 1360 Willow Road

Menlo Park, CA 94025
Filename: $\quad$ WTO08T01

Standard: $\quad$ ASTM E96-94

Material Log \#: 96008-128-15

Test Dates: $\quad 3 / 4 / 96$

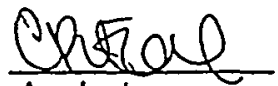

Analyst 2it $3 / 6 / 96$

QC/Date

\section{WATER VAPOR TRANSMISSION TEST REPORT}

Material Rame:

MTR - 1

Diameter of Sample:

6.25 Centimeters

Area of Sample:

0.00317 Square Meters

\begin{tabular}{|c|c|c|c|c|c||}
\hline $\begin{array}{c}\text { Time } \\
\text { (Hours) }\end{array}$ & $\begin{array}{c}\text { Cell 1 } \\
\text { Weight }\end{array}$ & $\begin{array}{c}\text { Cell 2 } \\
\text { Weight }\end{array}$ & $\begin{array}{c}\text { Cell 3 } \\
\text { Weight }\end{array}$ & $\begin{array}{c}\text { Averag } \\
\text { Weight }\end{array}$ & $\begin{array}{c}\text { Average } \\
\text { Weight Loss }\end{array}$ \\
\hline \hline 0 & 128.49 & 128.81 & 128.52 & 128.61 & 0.00 \\
\hline 2 & 128.31 & 128.66 & 128.32 & 128.43 & -0.18 \\
\hline 3 & 128.17 & 128.52 & 128.19 & 128.29 & -0.31 \\
\hline 4 & 128.08 & 128.40 & 128.07 & 128.18 & -0.42 \\
\hline 5 & 127.97 & 128.31 & 127.95 & 128.08 & -0.53 \\
\hline 6 & 127.85 & 128.21 & 127.86 & 127.97 & -0.63 \\
\hline
\end{tabular}

Weight in Grams

Water Vapor Transmission Rate: $\quad 33.99 \mathrm{~g} / \mathrm{h} / \mathrm{m}^{\wedge} 2$

Comments: See attached graph

These data are derived from lests performed in accordance with ASTM Standard E 96-94. These tests were performed under laboratory conditions and not under actual usage conditions. TRI Emironmental, Inc. makes no warranties or other guarantees concerning protection by this material and assume no liability for use of this material. The user should delermine the applicability of lest conditions when assessing suitability of material for actual anticipated exposure. 


\section{Average Weight Loss}

MTR- 1

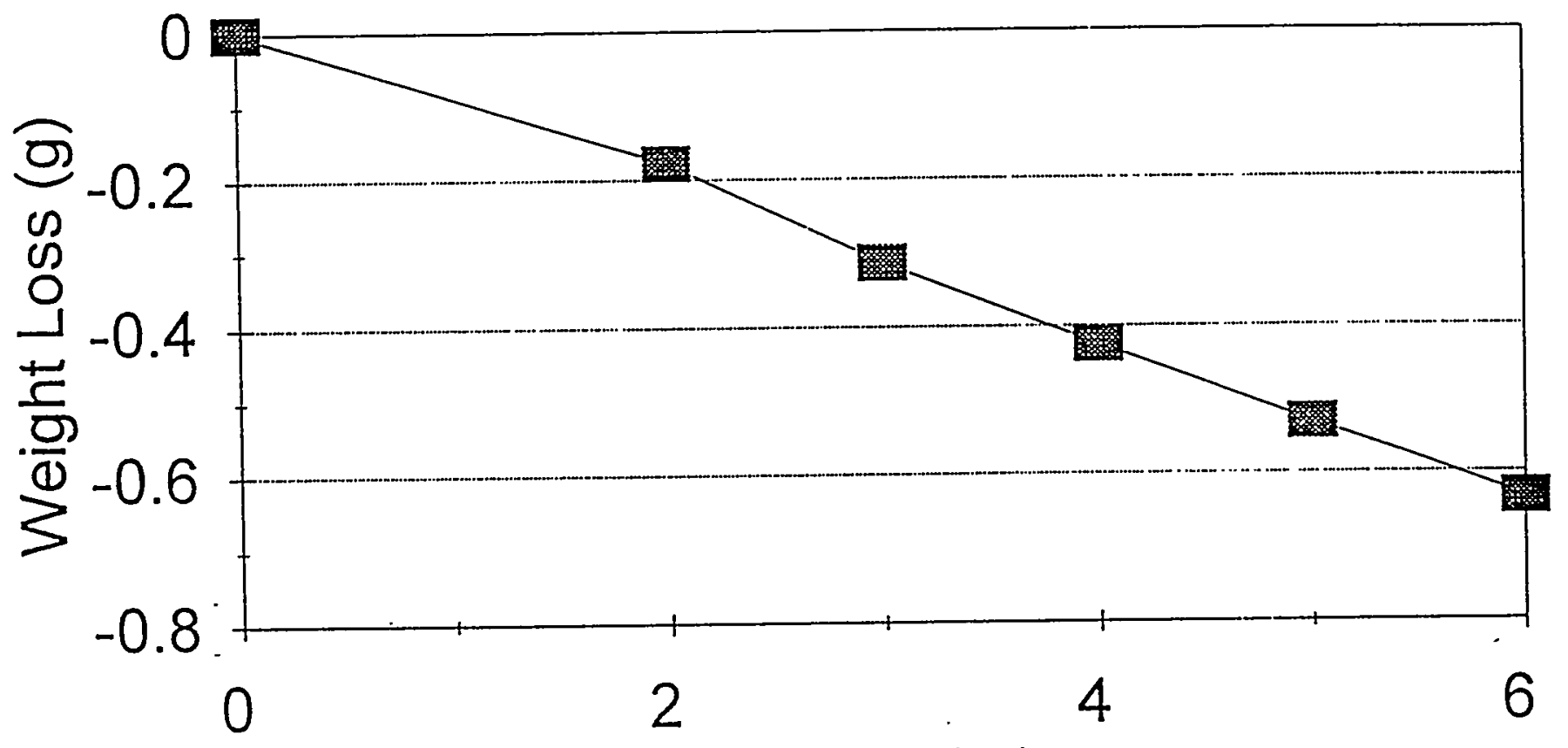

Time (Hrs) 
TEXTILE TEST RESULTS

Membrane Technology \& Research

Project \#: 96008

Hydrostatic Resistance (FTMS 5512)

P.O. \#: 0014754

TEST REPLICATE NUMBER

MEAN STD

PROJECT SPEC

\begin{tabular}{|lllllllll|l|l|}
\hline Material: MTR-1, before abrasion & 1 & 2 & 3 & 4 & 5 & & \\
Hydrostatic Resistance (psi) & 85 & 85 & 86 & 83 & 85 & 85 & 1 \\
\hline Material: MTR-1, after abrasion & & & & & & & \\
Hydrostatic Resislance (psi) & 82 & 85 & 82 & 82 & 83 & 83 \\
\hline
\end{tabular}

\begin{tabular}{|c|c|c|c|c|c|c|c|c|}
\hline \multicolumn{9}{|c|}{ Material: MTR-2, before abrasion } \\
\hline Hydrostatic Resistance (psi) & 115 & 110 & 112 & 112 & 113 & 112 & 2 & N/A \\
\hline \multicolumn{9}{|c|}{ Material: MTR-2, after abrasion } \\
\hline Hydrostatic Resistance (psi) & 110 & 109 & 110 & 108 & 109 & 109 & 1 & N/A \\
\hline . & & & & & & -3 & & \\
\hline
\end{tabular}

The testing herein is based upon accepled industry practice as well as the test method listed. TRI neither accepts responsibility for nor makes ciaim as to the final use and purpose of the material.

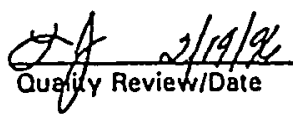




\section{LABORATORY ANALYSIS REPORT \\ STRENGTH AND ELONGATION - GRAB METHOD}

TRI/Environmental, inc.

9063 Bee Cave Rd.

Austin, TX 78733

Membrane Technology \& Research

\begin{tabular}{|l|l|}
\hline METHOD & FTMS 5100 \\
\hline LOG NO. & $96008-128-15$ \\
\hline DATE & $1-24-95$ \\
\hline MATERIAL & $\begin{array}{l}\text { MTR-1 } \\
\text { (yellow) }\end{array}$ \\
\hline
\end{tabular}

1360 Willow Road

Menlo Park, CA 94025
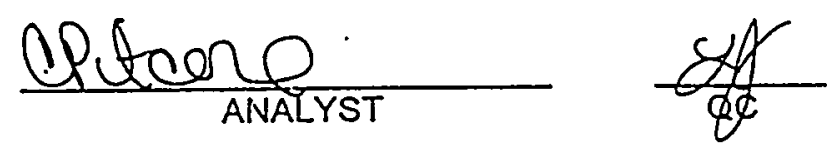

\begin{tabular}{||cc|}
\hline *SAMPLE & \\
NUMBER & LOAD (lb) \\
\hline$M 1$ & 109.27 \\
M2 & 107.09 \\
$M 3$ & 104.21 \\
$M 4$ & 108.89 \\
M5 & 111.49 \\
& \\
\hline AVG & 108.19 \\
STD & 2.43 \\
\hline & \\
XM1 & 84.95 \\
XM2 & 79.57 \\
XM3 & 76.67 \\
XM4 & 75.52 \\
XM5 & 79.09 \\
& \\
\hline AVG & 79.16 \\
STD & 3.26 \\
\hline
\end{tabular}

* $M$ denotes machine direction sample.

$X M$ denotes cross machine direction sample. 


\section{LABORATORY ANALYSIS REPORT STRENGTH AND ELONGATION - GRAB METHOD}

TRI/Environmental, inc. 9063 Bee Cave Rd. Austin, TX 78733

Membrane Technology \& Research 1360 Willow Road

Menlo Park, CA 94025

\begin{tabular}{|l|l|}
\hline METHOD & FTMS 5100 \\
\hline LOG NO. & $96008-128-16$ \\
\hline DATE & $1-24-95$ \\
\hline MATERIAL & $\begin{array}{l}\text { MTR-2 } \\
\text { (white) }\end{array}$ \\
\hline
\end{tabular}
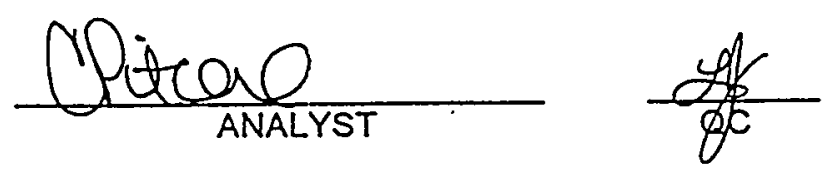

\begin{tabular}{|cc|}
\hline *SAMPLE & \\
NUMBER & LOAD $(\mathrm{lb})$ \\
\hline$M 1$ & 114.68 \\
$M 2$ & 127.25 \\
$M 3$ & 135.48 \\
$M 4$ & 113.22 \\
$M 5$ & 104.80 \\
& \\
\hline AVG & 119.08 \\
STD & 10.89 \\
\hline & \\
XM1 & 99.41 \\
XM2 & 123.79 \\
XM3 & 114.95 \\
XM4 & 118.18 \\
XM5 & 105.53 \\
& \\
\hline AVG & 112.37 \\
STD & 8.78 \\
\hline
\end{tabular}

" $M$ denotes machine direction sample.

XM denotes cross machine direction sample. 


\section{LABORATORY ANALYSIS REPORT}

\section{FLEX DURABILITY}

TRI/Environmental, Inc. 9063 Bee Cave Road Austin, Texas 78733-6201

Membrane Technology \& Research 1360 Willow Road Menlo Park, CA 94025

\begin{tabular}{|l|l|}
\hline METHOD NO. & ASTM F392 \\
\hline JOB NO. & 96008 \\
\hline LOG NO. & $96008-128-15$ \\
\hline DATE & $3 / 9 / 95$ \\
\hline MATERIAL & MTR-1 \\
\hline
\end{tabular}

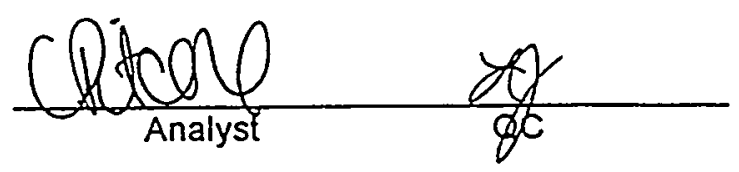

*Sample full flexed for 1 hour.( 2700 cycles)

\begin{tabular}{ccc} 
Sample & $\begin{array}{c}\text { Pinholes } \\
\text { On Unflexed } \\
\text { Control }\end{array}$ & $\begin{array}{c}\text { Pinholes On } \\
\text { 48 Sq In } \\
\text { Of Flexed } \\
\text { Sample }\end{array}$ \\
\hline M1 & 0 & 8 \\
M2 & 0 & 5 \\
M3 & 0 & 0 \\
M4 & 0 & 2 \\
\hline Avg: & 0 & 4 \\
Std.Dev: & 0 & 3 \\
\hline XM1 & 0 & 0 \\
XM2 & 0 & 3 \\
XM3 & 1 & 4 \\
XM4 & 0 & 0 \\
\hline Avg: & 0 & 2 \\
Std.Dev: & 0 & 2 \\
\hline
\end{tabular}

MD signifies machine direction sample

XM signifies cross machine direction sample

"Samples were tested per Condition A.

4.3.1 The various conditions described in this procedure are to prevent testing a structure under conditions that either give too many holes to effectively count and be significant (normally greater than 50 ), or too few to be significant (normally less than five per sample). 


\title{
LABORATORY ANALYSIS REPORT
}

\author{
FLEX DURABILITY
}

TRI/Environmental, Inc.

9063 Bee Cave Road

Austin, Texas 78733-6201

Membrane Technology \& Research

1360 Willow Road

Menlo Park, CA 94025

\begin{tabular}{|l|l|}
\hline METHOD NO. & ASTM F392 \\
\hline JOB NO. & 96008 \\
\hline LOG NO. & $96008-128-16$ \\
\hline DATE & $3 / 9 / 95$ \\
\hline MATERIAL & MTR-2 \\
\hline
\end{tabular}

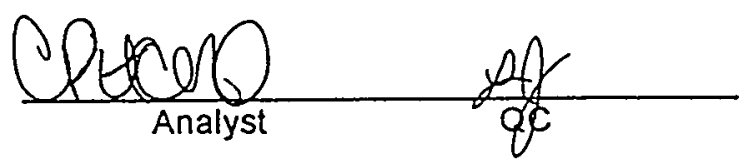

*Sample full flexed for 1 hour.( 2700 cycles)

\begin{tabular}{ccc} 
Sample & $\begin{array}{c}\text { Pinholes } \\
\text { On Unflexed } \\
\text { Control }\end{array}$ & $\begin{array}{c}\text { Pinholes On } \\
\text { 48 Sq in } \\
\text { Of Flexed } \\
\text { Sample }\end{array}$ \\
\hline M1 & 0 & 0 \\
M2 & 0 & 0 \\
M3 & 0 & 3 \\
M4 & 0 & 1 \\
\hline Avg: & 0 & 1 \\
Std.Dev: & 0 & 1 \\
\hline XM1 & 0 & 1 \\
XM2 & 0 & 0 \\
XM3 & 0 & 2 \\
XM4 & 0 & 0 \\
\hline Avg: & 0 & 1 \\
Std.Dev: & 0 & 1 \\
\hline
\end{tabular}

MD signifies machine direction sample

$X M$ signifies cross machine direction sample

*Samples were tested per Condition A.

4.3.1 The various conditions described in this procedure are to prevent testing a structure under conditions that either give too many holes to effectively count and be significant (normally greater than 50 ), or too few to be significant (normally less than five per sample). 


\section{LABORATORY ANALYSIS REPORT \\ ELMENDORF TEAR STRENGTH}

TRI/Environmental, Inc.

9063 Bee Cave Rd.

Austin, TX 78733

Membrane Technology \& Research 1360 Willow Road

Menlo Park, CA 94025

\begin{tabular}{|l|l|}
\hline Method No. & ASTM D1424 \\
\hline Job No. & 96008 \\
\hline Log No. & $96008-128-15$ \\
\hline Date & $3 / 12 / 96$ \\
\hline Material & MTR- 1 \\
\hline
\end{tabular}
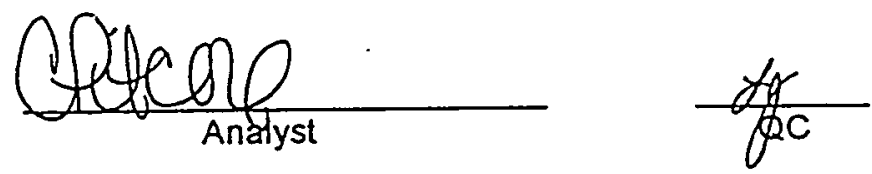

\begin{tabular}{|cc|}
\hline $\begin{array}{c}\text { *Sample } \\
\text { Number }\end{array}$ & $\begin{array}{c}\text { Tear } \\
\text { Strength (g) }\end{array}$ \\
\hline MD1 & 1408 \\
MD2 & 1216 \\
MD3 & 1472 \\
MD4 & 1280 \\
MD5 & 1472 \\
& \\
\hline Avg & 1370 \\
Std Dev & 104 \\
\hline & \\
XM1 & 1856 \\
XM2 & 1920 \\
XM3 & 1920 \\
XM4 & 1728 \\
XM5 & 1792. \\
& \\
\hline Avg & 1843 \\
Std Dev & 75 \\
\hline
\end{tabular}

"MD denotes machine direction sample; XM denotes cross machine direction sample. 


\section{LABORATORY ANALYSIS REPORT}

\section{ELMENDORF TEAR STRENGTH}

TRI/Environmental, Inc. 9063 Bee Cave Rd.

Austin, TX 78733

Membrane Technology \& Research 1360 Willow Road Menlo Park, CA 94025

\begin{tabular}{|l|l|}
\hline Method No. & ASTM D1424 \\
\hline Job No. & 96008 \\
\hline Log No. & $96008-128-16$ \\
\hline Date & $3 / 12 / 96$ \\
\hline Material & MTR-2 \\
\hline
\end{tabular}
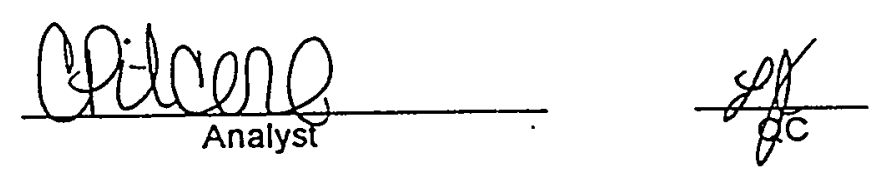

\begin{tabular}{|c|c|}
\hline $\begin{array}{l}\text { Sample } \\
\text { Number }\end{array}$ & $\begin{array}{c}\text { Tear } \\
\text { Strength (g) }\end{array}$ \\
\hline $\begin{array}{l}\text { MD1 } \\
\text { MD2 } \\
\text { MD3 } \\
\text { MD4 } \\
\text { MD5 }\end{array}$ & $\begin{array}{c}1024 \\
1024 \\
1024 \\
896 \\
896\end{array}$ \\
\hline $\begin{array}{r}\text { Avg } \\
\text { Std Dev } \\
\end{array}$ & $\begin{array}{l}973 \\
63 \\
\end{array}$ \\
\hline $\begin{array}{l}X M 1 \\
X M 2 \\
X M 3 \\
X M 4 \\
X M 5\end{array}$ & $\begin{array}{l}2752 \\
1984 \\
1664 \\
2368 \\
2752\end{array}$ \\
\hline $\begin{array}{r}\text { Avg } \\
\text { Std Dev }\end{array}$ & $\begin{array}{r}2304 \\
428 \\
\end{array}$ \\
\hline
\end{tabular}

*MD denotes machine direction sample; XM denotes cross machine direction sampie.

These tests were performed by an outside independent laboratory. 
APPENDIX F: SUIT EVALUATION REPORTS

F-1 


\section{Mrthri D Little}

\section{Evaluation of the Thermal \\ Characteristics of Four Haz-mat Suits}

Final Test Report

Prepared for:

Membrane Technology \& Research Inc.

February 27, 1996

Arthur D. Little, Inc.

Acorn Park

Cambridge, Massachusetts

02140-2390

Reference 57884 


\section{Objective and Scope}

Arthur D. Little, Inc., under contract from Membrane Technology \& Research Inc. was tasked to evaluate the insulation (clo) and moisture permeability $\left(\mathrm{i}_{\mathrm{m}}\right)$ characteristics of four Haz-mat suits; two which have been fabricated by Membrane Technology, the other two by commercial manufacturers.

Test Items

\begin{tabular}{|c|c|c|}
\hline Suit & $\begin{array}{c}\text { Weight } \\
\text { (lbs) }\end{array}$ & $\begin{array}{c}\text { Average Thickness } \\
\text { (mils) }\end{array}$ \\
\hline MTR-1 & 1.248 & 12 \\
\hline MTR-2 & 1.332 & 9 \\
\hline Saran & 0.872 & 9 \\
\hline Tyvek & 0.314 & 6 \\
\hline
\end{tabular}

The undergarments consisted of jockey shorts, tee shirt, and cotton socks. Also included for each test were neoprene gloves and typical work boots. All measurements were taken with the manikin's hair in place on the head. The hoods provided with the Haz-mat suits were run in the up position.

\section{Approach}

Heat loss can be measured using a life-sized, heated, thermal manikin with thermally isolated sectional body heaters, controllers, and temperature sensors. Such heat loss can be measured with the manikin's skin "dry," to determine convection and radiation heat loss, or "wet" for measurement of sweat evaporative cooling. Both dry and wet measurements must be made under closely controlled ambient environmental conditions of air (and radiant) temperature and humidity.

\section{Test Apparatus}

\section{The Heated Copper Manikin}

Thermal characteristics of the suits were measured using a life-sized, copper manikin. The manikin is typically used to measure the insulation (clo) against heat loss of clothing systems, or components thereof. The method is described in ASTM Standard Method F1291. Briefly, a thermal manikin is an instrument that is equipped with heaters and thermal sensors, in or under its copper skin The temperature of each section of a "sectional" manikin can be set, by that section's control, to maintain a constant skin temperature. 


\section{The Climate Controlled Test Chamber}

The manikin is maintained inside an $11 \times 14$ foot chamber in which the temperature and humidity are controlled to meet the specific requirements of the test. The conditioned air enters the room approximately seven feet from the front side of the manikin. The air velocity at the manikin can be adjusted from 0.5 to approximately 20 miles per hour.

\section{Test Measurements}

The thermal effects of clothing on its wearer can be readily characterized by two key heat transfer characteristics:

1. the convective and radiant heat transfer from the body, when wearing clothing; this is most easily understood when expressed in "clo" units of thermal insulation around the body, and

2. the evaporative heat transfer from a sweating body, when wearing clothing; this is most easily understood when expressed as the "permeability index" $\left(i_{m}\right)$, since the "permeability index ratio" $\left(i_{m} / c l o\right)$ directly expresses the maximum attainable percentage of the evaporative cooling available in any given environment.

\section{Measurement of Thermal Insulation}

To measure the insulation covering any given manikin section, the normal temperature for that section is used as a setpoint, e.g., the temperature of a human torso is usually about $33^{\circ} \mathrm{C}$. At equilibrium (i.e., after coming into a steady state of thermal balance) the amount of heat required by the heaters of a given section, to precisely maintain this setpoint temperature, is exactly equal to the heat lost from the section. This measured non-evaporative heat loss is a direct result of two factors:

1. the overall average insulation around that section of the body; and

2. the difference between the dry, skin surface temperature and the air temperature.

Thus, to calculate the insulation around the body, the manikin must be operated in a climatic chamber set at a specified, and constant, air temperature.

\section{Measurement of Moisture Permeability}

The skin must be wetted to measure the "evaporative" heat loss from a given section. The manikin's cotton skin is initially sprayed with water at approximately $36^{\circ} \mathrm{C}$, the temperature at which human skin produces sweat, until the skin is saturated. Then the manikin is dressed with the standard undergarment and the suit to be tested. Rewetting, which may be, required because of drying of the wetted skin, is indicated by a fall in the measured permeability index value from one run to the next. Rewetting is accomplished by removing the suit or, preferably when possible, opening and inserting the water spray 
nozzle against the skin under the suit. After the added water is heated to the setpoint skin temperature, a steady state, evaporative heat loss can be achieved. This heat loss must be replaced by the heaters to maintain the setpoint skin temperature. The electrical energy required to maintain setpoint temperature is exactly equal to the sum of the, previously measured, non-evaporative heat loss plus the evaporative heat loss. Steady state heat loss must be measured before the skin begins to dry out. The measured "evaporative" heat loss is also a function of two factors:

1. the overall average moisture permeability of the insulation around that section of the body; and

2. the difference between the vapor pressure at the wet skin and the vapor pressure of the ambient air.

\section{Maximum Heat Loss}

In summary, by measuring the amount of heat (in the form of electrical energy) that must be put into the manikin to maintain sectional temperatures at preset values, one can calculate (1) the thermal insulation (clo), when the skin is dry, and (2) the moisture permeability $\left(\mathrm{i}_{m}\right)$, when the skin is wet, for any covering (including the trapped and surface air layers) over any section of the manikin. The manikin has 15 , independently heated, thermostated and measured areas. In the present study, the data from the foot section was excluded.

\section{Climate Conditions Used}

The chamber conditioner was set to produce an air temperature of $20^{\circ} \mathrm{C}$ and $50 \% \mathrm{RH}$. These environmental conditions have been shown, in previous tests, to best differentiate heat loss between Haz-mat suit types. Air speed was set at $1.5 \mathrm{mph}$.

\section{Definition of Collected and Calculated Values}

The comfort characteristics measured included the overall effective insulation (clo) and the moisture permeability $\left(\mathrm{i}_{\mathrm{m}}\right)$.

\section{Insulation Values (clo)}

The insulation (clo) added by a garment to the body allows direct calculations of the heat that can be transferred between the dry body and the ambient air. One clo unit of insulation is approximately equal to the intrinsic insulation of a man's suit of winter weight. One equates to a heat loss for an average adult man (with $1.8 \mathrm{~m}^{2}$ of body surface area) of $10 \mathrm{kcal}$ per hour for each ${ }^{\circ} \mathrm{C}$ difference between his skin temperature (usually about $33^{\circ} \mathrm{C}$ for comfort; about $36^{\circ} \mathrm{C}$ when hot and sweaty) and the ambient air temperature. 


\section{Moisture Permeability $\left(i_{m}\right)$}

The moisture vapor permeability index $\left(\mathrm{i}_{\mathrm{m}}\right)$ is a dimensionless value that represents the relative ease with which moisture vapor can pass through the garment/item. The scale is from zero to one; an $\mathrm{i}_{\mathrm{m}}$ value of zero indicates zero permeability for moisture vapor, as would be found in a closely fitting, sealed, rubber suit. An $i_{m}$ value of one indicates no hindrance to moisture vapor loss; moisture can evaporate at the maximum rate for the given environment, i.e., a rate equivalent to that from the wet bulb of a ventilated wet bulb thermometer. An $i_{m}$ measurement from a garment is an "effective" value that indicates the loss of moisture into the air spaces inside the garment, and then from any gaps between the suit and the body, as well as permeation through the suit.

\section{Permeability Index Ratio (i.jclo)}

The permeability index ratio $\left(\mathrm{i}_{\mathrm{m}} / \mathrm{clo}\right)$ simply combines the thermal insulation and moisture permeability. It numerically represents that percentage of the maximum evaporative cooling power, available in a given environmental combination of air temperature and relative humidity, that can be obtained by the wearer of that clothing item or ensemble. An $\mathrm{i}_{\mathrm{m}}$ of 0.20 means that the item limits evaporative cooling to $20 \%$ of the total evaporative cooling available in any given environment. The overall permeability index ratio ( $\mathrm{i}_{\mathrm{m}} / \mathrm{clo}$ ) of 0.20 means that the item limits evaporative cooling to $20 \%$ of the total evaporative cooling available in any given environment. The overall permeability index ratio $\left(\mathrm{i}_{\mathrm{m}} / \mathrm{clo}\right) \mathrm{can}$ be calculated for the body for each suit for the various body sections. Whenever the human body has to depend on sweat evaporation for regulation of body temperature, this ratio ( $\mathrm{i}_{\mathrm{m}} / \mathrm{clo}$ ) is the key value indication the body's capacity to get cooling by evaporative heat transfer from the body, through the protective suit or any uncovered area, to the environment.

A difference of $0.01\left(\mathrm{i}_{\mathrm{m}} / \mathrm{clo}\right.$ ) between clothing items may be subjectively perceivable under ideal test conditions, but is highly unlikely to produce measurable differences in such physiological responses as heart rate, sweat rate, skin or deep body temperature. Generally, differences of $0.05\left(\mathrm{i}_{\mathrm{m}} / \mathrm{clo}\right)$ are easily sensed and produce measurable differences in physiological response, during exposures to mild heat stress, where body temperature regulation depends on sweat evaporative cooling.

\section{Results}

Baseline measurements for the nude manikin are shown in Table 1. The insulation and moisture permeability data summarized for the four suits are presented in Table 2 and Charts 1 through 3 . In all cases, six consecutive values were measured and a mean and standard deviation were calculated. 


\section{Membrane Technology Haz-mat Suit Test Results}

\section{Manikin \\ Section}

MTR-1 Suit
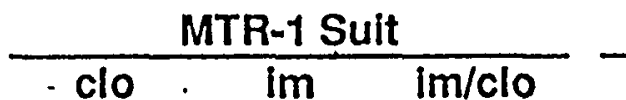

$\frac{\text { MTR-2 Suit }}{\text { clo } \quad \mathrm{im} \quad \mathrm{im} / \mathrm{clo}}$

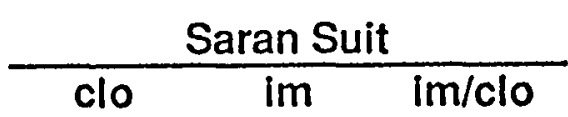

$\frac{\text { Tyvek Suit }}{\text { clo } \mathrm{im} \quad \mathrm{im} / \mathrm{clo}}$

Head

Torso

Arm

Fore-Arm

0.89

$0.31 \quad 0.35$

0.19

0.14

1.31

0.97

0.82

Hand

1.17

0.15

0.11

0.15

0.16

0.13

0.16

0.17

1.15

0.23

0.14

0.20

Overall

1.16

0.20

0.17

0.87

1.20

$0.30 \quad 0.34$

0.20

0.17

0.17

0.13

0.97

0.13

0.13

0.73

0.08

0.11

1.09

1.10

0.18

0.14

0.17

1.10

0.18

0.16

0.88
1.25

0.24

0.16

0.27

0.12

1.41

0.10

0.07

0.12

0.12

0.70

0.10

0.14

0.13

1.12

0.18

0.11

0.16

0.16

0.14

1.10

0.84

1.19

1.29

0.95

0.70

1.14

0.35

0.24

0.24

0.26

0.16

0.24

0.30

0.42

0.21

0.18

0.27

0.22

1.09

0.28

0.21

0.28

\section{Predicted Heat loss of Suits (k-cal)}

MTR-1 Suit 75F 50\%rh 85F 50\%rh 95F 50\%rh

MTR-2 Suit

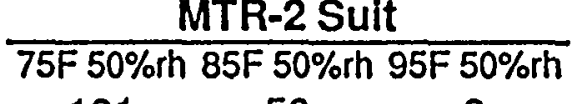

Saran Suit

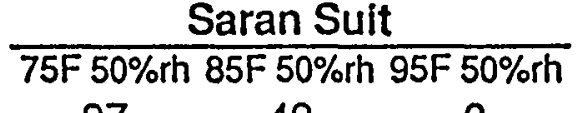

\begin{tabular}{ccc}
\multicolumn{3}{c}{ Tyvek Suit } \\
\hline 75 F 50\%rh & 85 F $50 \%$ rh & 95F $50 \%$ rh \\
101 & 50 & 0 \\
172 & 146 & 120 \\
273 & 196 & 120
\end{tabular}

\section{Mrthur D Little}




\section{Membrane Technology Haz-mat Suit Test Results}

\begin{tabular}{lcc}
$\begin{array}{l}\text { Manikin } \\
\text { Section }\end{array}$ & $\begin{array}{c}\text { Nude Baseline (with hair) } \\
\text { clo }\end{array}$ & $\begin{array}{c}\text { Undergarment Baseline } \\
\text { clo }\end{array}$ \\
\cline { 1 - 2 } Head & 0.67 & 0.67 \\
Torso & 0.46 & 0.94 \\
Arm & 0.45 & 0.69 \\
Fore-Arm & 0.41 & 0.41 \\
Hand & 0.36 & 0.35 \\
Thigh & 0.44 & 0.49 \\
Calf & 0.52 & 0.61 \\
Foot & 0.48 & 0.78 \\
& &
\end{tabular}


Chart 1.

Insulation (clo) of $4 \mathrm{Haz}-m a t$ Suits

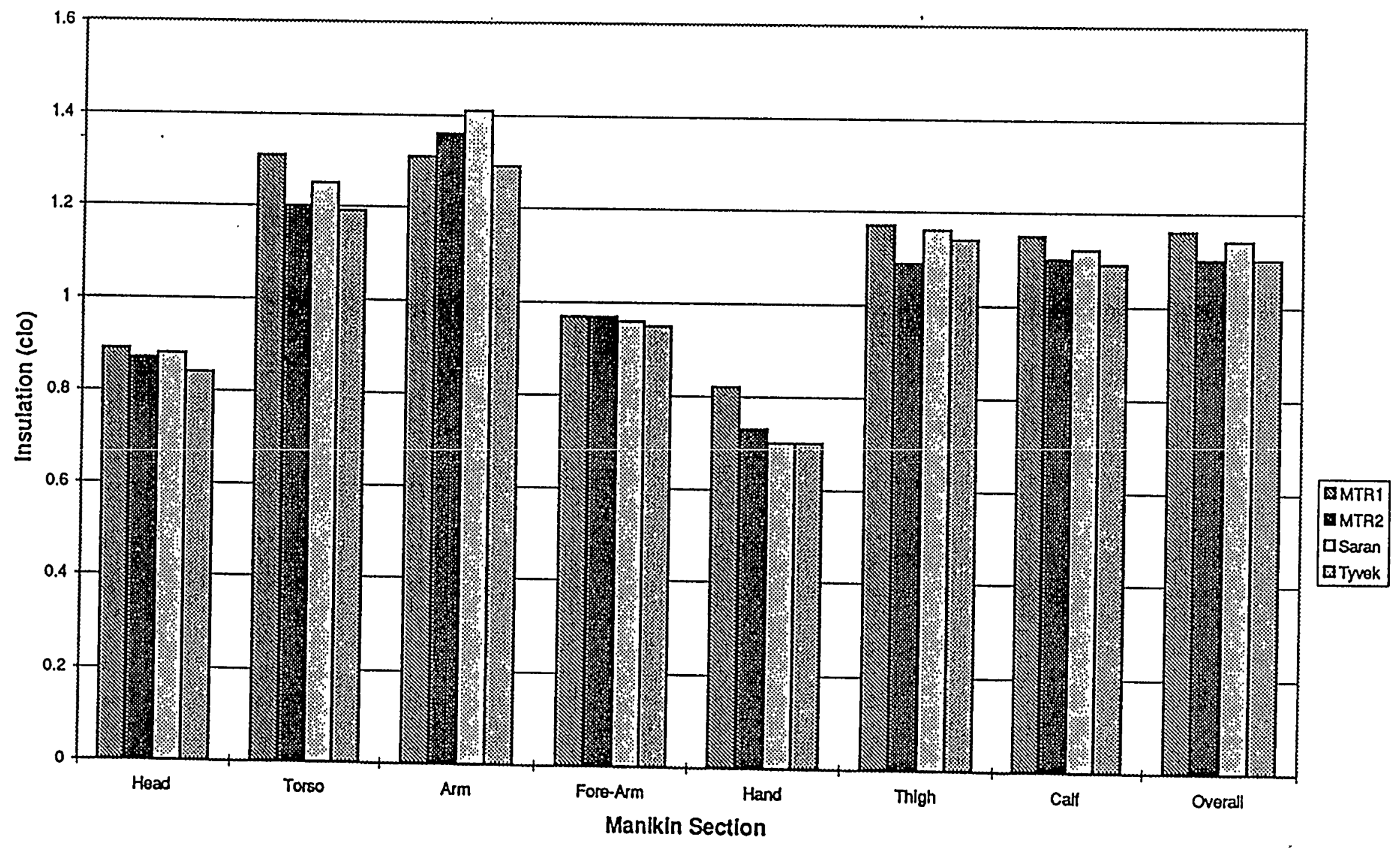

Arthur D Little 


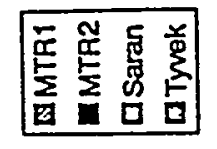

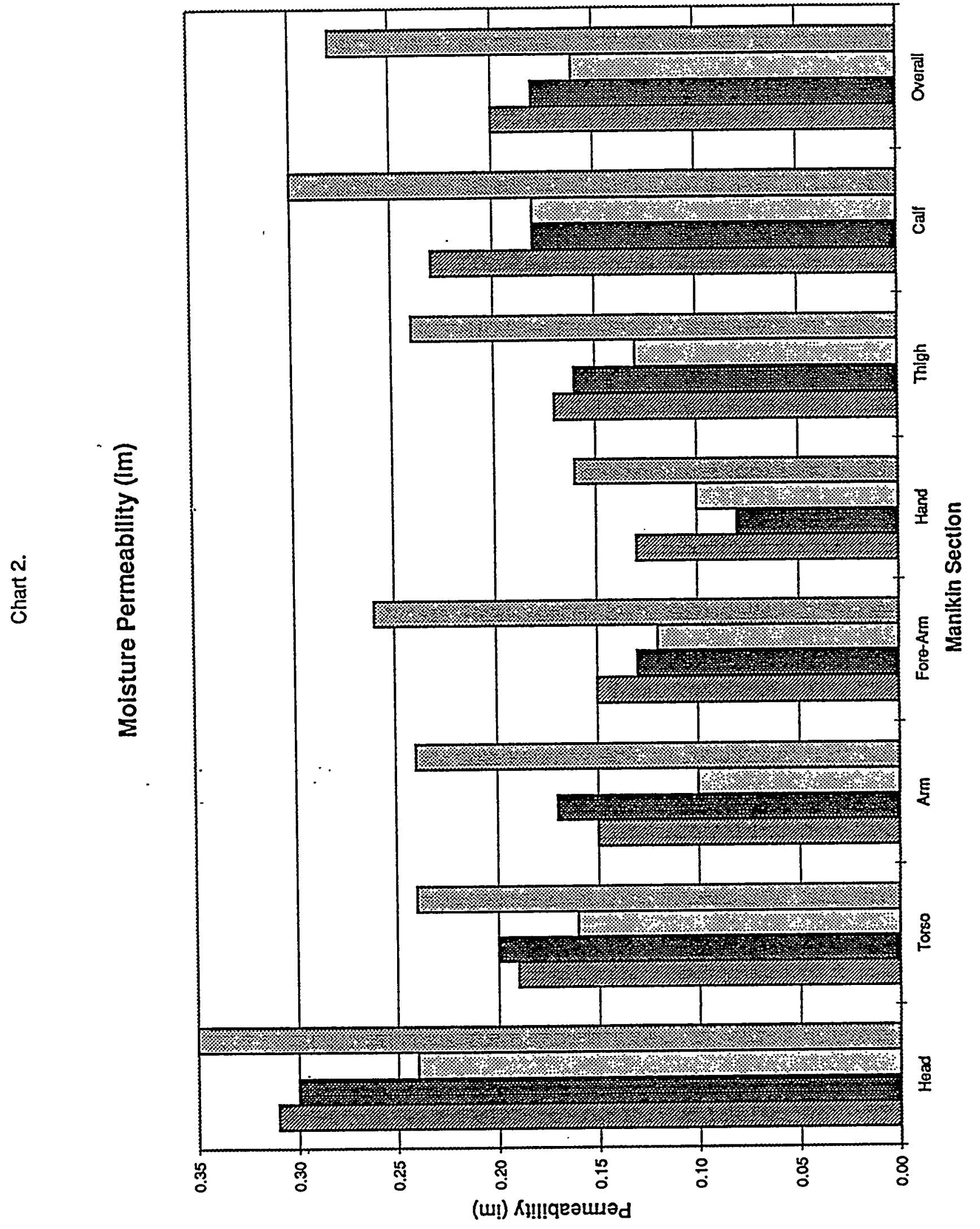




\section{Permeability Index Ratio (Im/clo)}

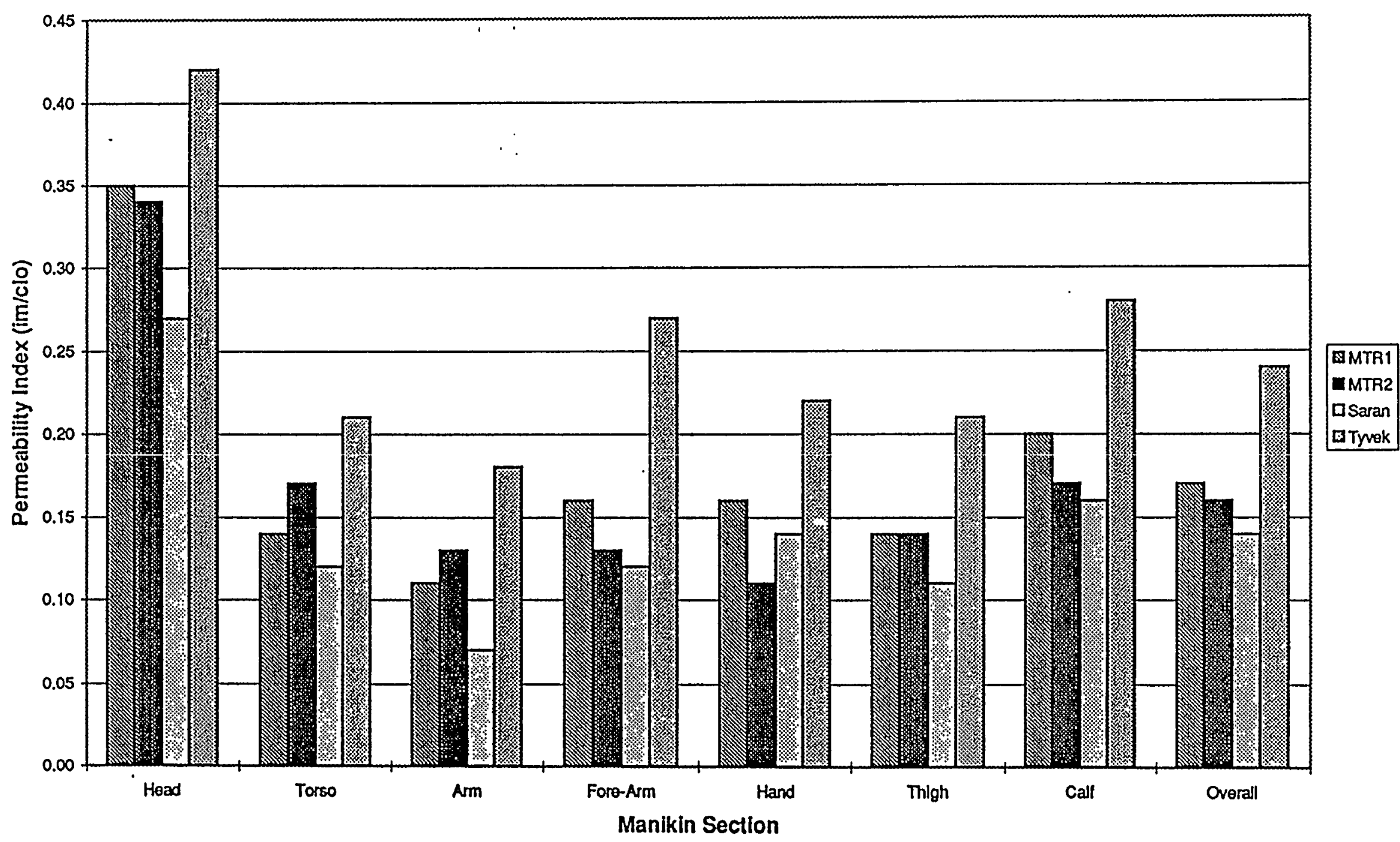

Artlur D Little 


\title{
Evaluation of Heat Stress Associated with Haz-mat Suits
}

\author{
Prepared for \\ Membrane Technology \& Research, Inc.
}

by

Byron W. Jones

May 1996

\section{Background Information}

This report summarizes computer modeling of heat stress that results from wearing four different Haz-mat suits each consisting of a coverall with an attached hood. The coveralls were identified by MTR as follows:

\author{
MTR-1 \\ MTR-2 \\ Saranex on Tyvek \\ Tyvek
}

Thermal manikin data collected by Arthur D. Little, Inc. were provided by MTR to characterize the thermal insulation and water vapor permeability of the coveralls. The suits were constructed by MTR from the same pattern and to the extent possible were identical in geometry except for the differences in materials from which they were constructed. The manikin tests were conducted with the suits worn over jockey shorts, a T-shirt, and socks. The manikin wore work boots and neoprene gloves and the hood was in the raised and closed position for all tests.

Computer model runs were conducted with the KSU segmented-two node model of the human body. This model is a transient thermal model of the human body-clothing system. It is described in the references listed at the end of this report. The model allows very detailed clothing descriptions to be reflected in the modeling. These descriptions include the coverage and layering of each garment on the body and the tightness of fit of each garment. Also the thickness, thermal insulation, water vapor permeability, moisture adsorbtance, thermal capacitance, and density of each material in the clothing may be specified. The activity of the person is specified as a work rate and the environment is specified according to air temperature, humidity, thermal radiation, and air velocity. The model calculates the transient heat exchange with the environment and the transient thermal response of the body including the thermal regulatory mechanisms of vasodilatation and sweating. For the purpose of this evaluation, the net heat gain of the body was used as a measure of the heat load imposed on the wearer. This net heat gain is reflected in the rise in average body temperature. Two levels of heat stress are indicated. The first level is the voluntary tolerance limit (VTL). The VTL is the point at which a typical motivated individual will request to stop the activity. The second level is the extreme danger point. At this point, heat stroke and death are a real possibility. It should be realized that there are tremendous 
physiological and psychological variations from individual to individual. Some people will voluntarily work to the point of heat stroke while others will refuse further work at the first onset of heat stress. Likewise, a well acclimatized and physically fit individual will tolerate the physical rigors of heat stress far better than the unfit, unacclimatized individual. While the model gives results that are a good indication of how a typical person will respond and are very useful for comparing the impact of differences in clothing on heat stress, care should be exercised in attempting to apply the predictions to a specific individual in a specific situation.

\section{Clothing and Fabric Data Files}

An extensive data base of fabrics, garments, and clothing ensembles is maintained for use with the model. This data base includes over 40 ensembles and the garments and fabrics/materials represented in those ensembles. The properties and geometries of the undergarments, boots and gloves were obtained from garments and materials in the data base and were used with all four coveralls. Ideally, the exact geometries and material properties for each coverall would have been measured. The geometry information needed includes the coverage of each body part and the air spaces that exist between the coverall and the skin or undergarments for each part of the body. The material information needed includes the thermal resistance, the water vapor permeability, the thickness, the density, the moisture regain characteristic curve (or fiber content if made of standard fibers), and the thermal capacitance. The thermal manikin measurements describe the steady state heat and moisture characteristics of the clothing as a whole and do not provide these detailed data. Thus, some means to use the manikin data, and other information, to accurately estimate clothing geometry and key material properties was required.

Hooded coveralls in the data base were used to establish the coverage of each body part by the coveralls. With a relatively "thin," single layer garment such as the Haz-mat suits, the thickness of the air layer between the coverall and body has more impact on the thermal insulation that the suit creates than does the actual thermal resistance of the coverall material. The thickness of this air layer was determined by setting the thermal resistance of the coverall material to a typical value for this type of material and then adjusting the air layer by trial-and-error to achieve a heat loss predicted by the model in steady state that was consistent with the thermal insulation measured with the thermal manikin. This air layer thickness was then used for all four coveralls. The thermal resistance of each coverall material was then adjusted to account for the small differences in overall thermal insulation (clo) measured on the manikin. This adjustment too was a trial-anderror process. The evaporative resistance (a measure proportional to the inverse of the water vapor permeance) of each coverall material was then adjusted to provide heat loss by moisture evaporation in steady state consistent with the permeability $\left(i_{m}\right)$ measurements on the manikin. As above, this process was accomplished by trial-and-error. The sweating mechanism in the model was overridden for the above work to correctly simulate the conditions generated by the thermal manikin. When determining the air layer thickness and the thermal resistance, no sweating or moisture permeation through the skin was allowed. When determining the evaporative resistance, sufficient sweat was secreted to maintain the skin in a water saturated state. 
The thickness of each coverall material was specified by MTR. The density and thermal capacitance have little impact on the results for the simulations conducted and typical values from the data base were used. A non-hygroscopic moisture regain curve was used for all four coverall materials. The actual clothing data files used in the evaluations are included in Appendix 1. These files are rather complex and are included primarily to allow the simulations to be faithfully reproduced at a future time should that be necessary.

\section{Environment and Activity}

Two different activity levels specified by MTR were used in the simulations:

$\begin{array}{ll}\text { Light-Moderate } & 4 \mathrm{kcal} / \mathrm{min} \\ \text { Heavy } & 7 \mathrm{kcal} / \mathrm{min}\end{array}$

Three different environments specified by MTR were used:

$900^{\circ} \mathrm{F}$ air temperature and $40 \%$ relative humidity $90 \circ \mathrm{F}$ air temperature and $90 \%$ relative humidity $70{ }^{\circ} \mathrm{F}$ air temperature and $40 \%$ relative numidity

The person was in direct sunlight and there was minimal air motion in all cases. The actual input files are included in Appendix 2 for documentation purposes. The model requires the inputs to be specified in SI units and the effect of sunlight is specified as an equivalent radiant temperature of the environment.

\section{Results}

There were a total of 24 combinations of coveralls, activities, and environments. The results are presented in graphical form in the following six charts. In addition, tabulated model output is presented in Appendix 3. 
$4 \mathrm{kcal} / \mathrm{min}, 70 \mathrm{~F}, 40 \% \mathrm{RH}$, Direct Sun, No Wind

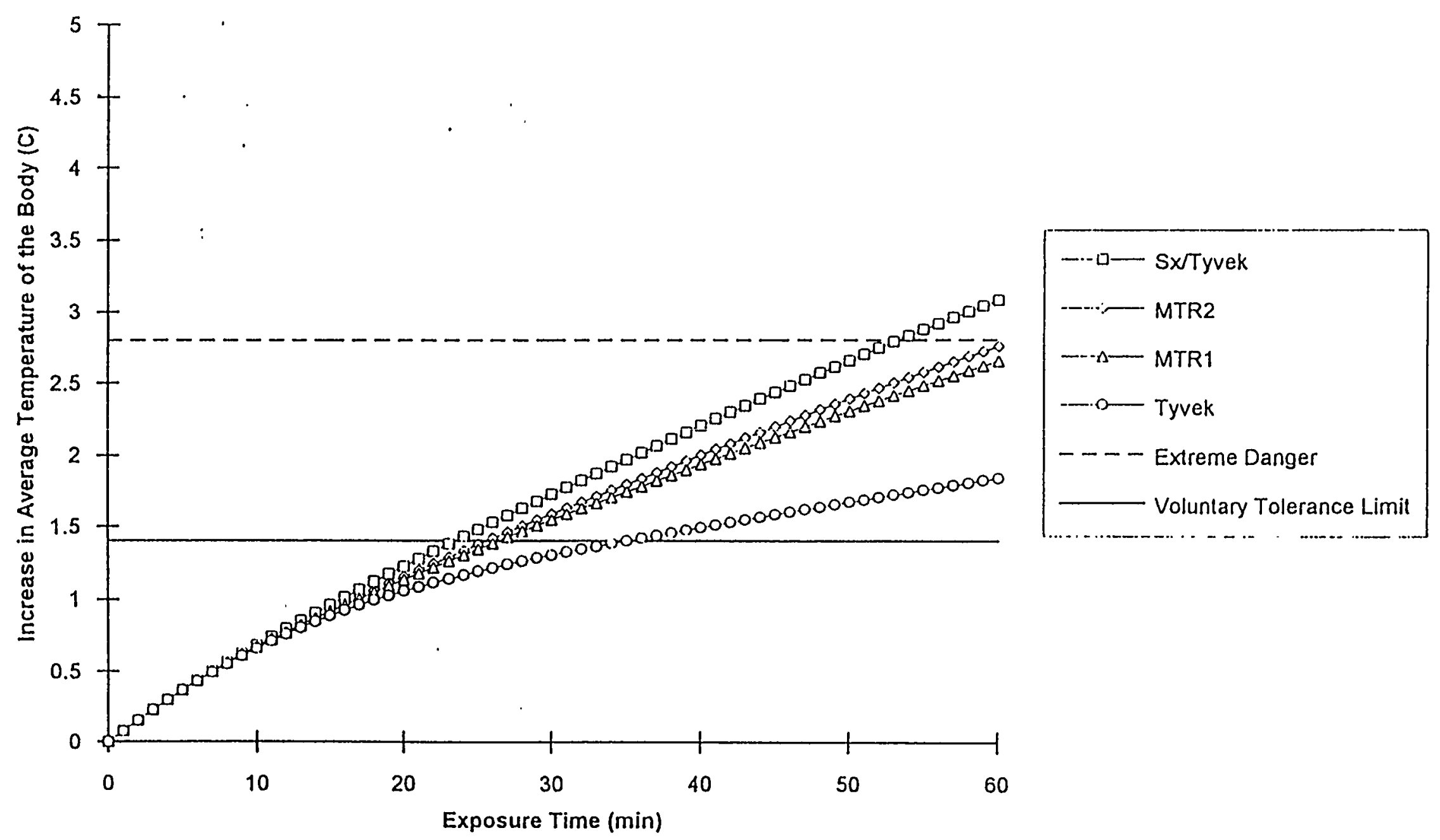




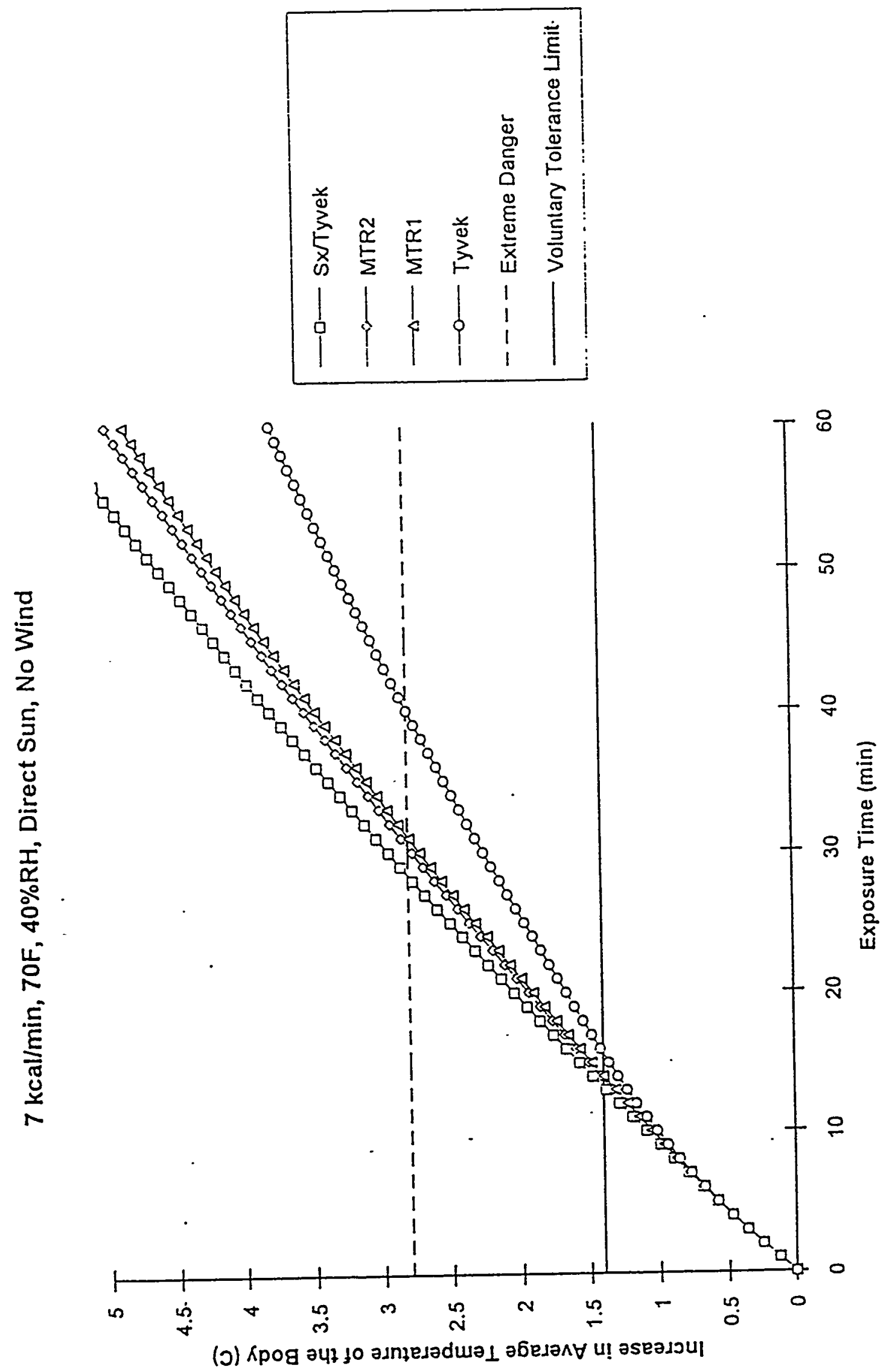




\section{$4 \mathrm{kcal} / \mathrm{min}, 90 \mathrm{~F}, 40 \% \mathrm{RH}$, Direct Sun, No Wind}

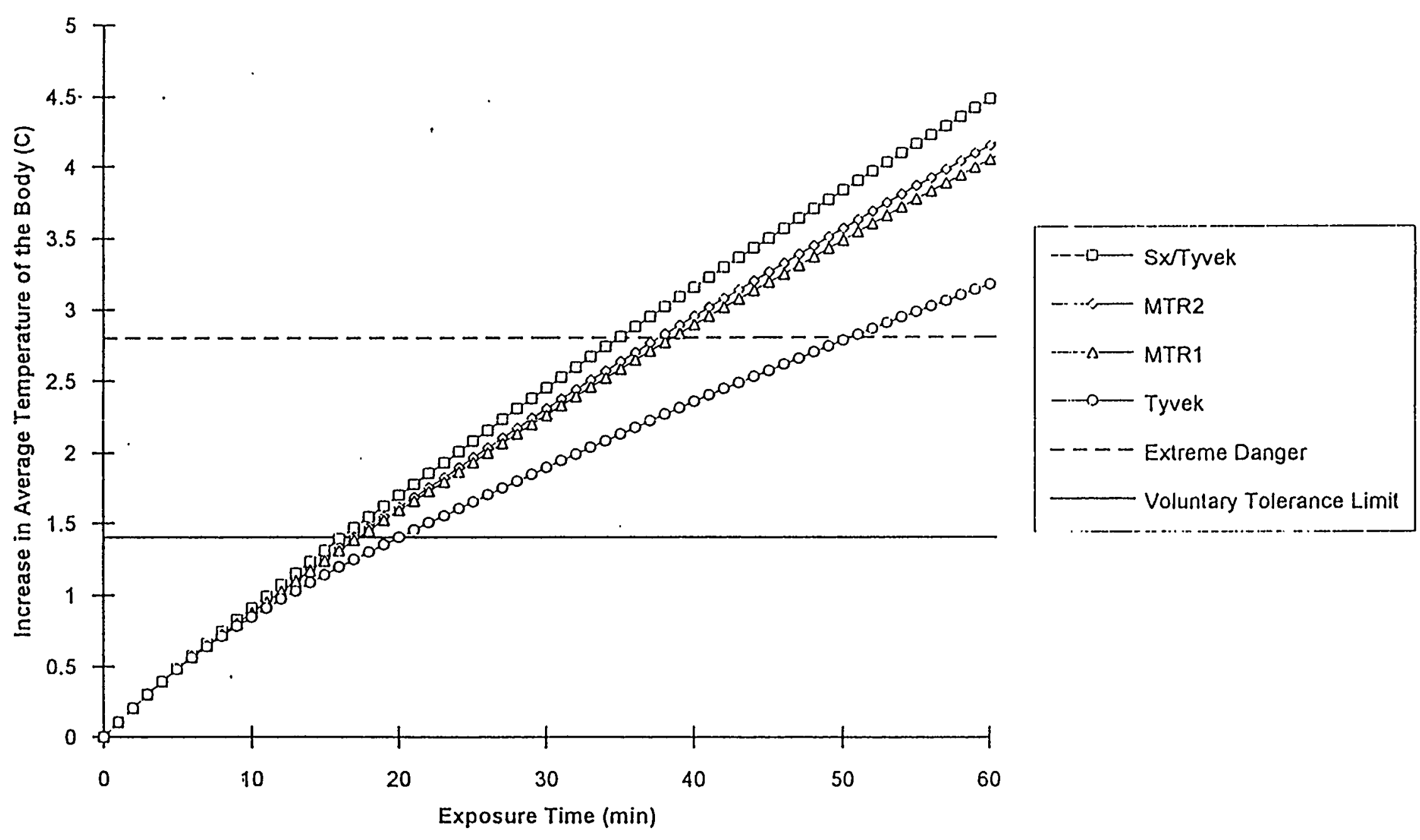




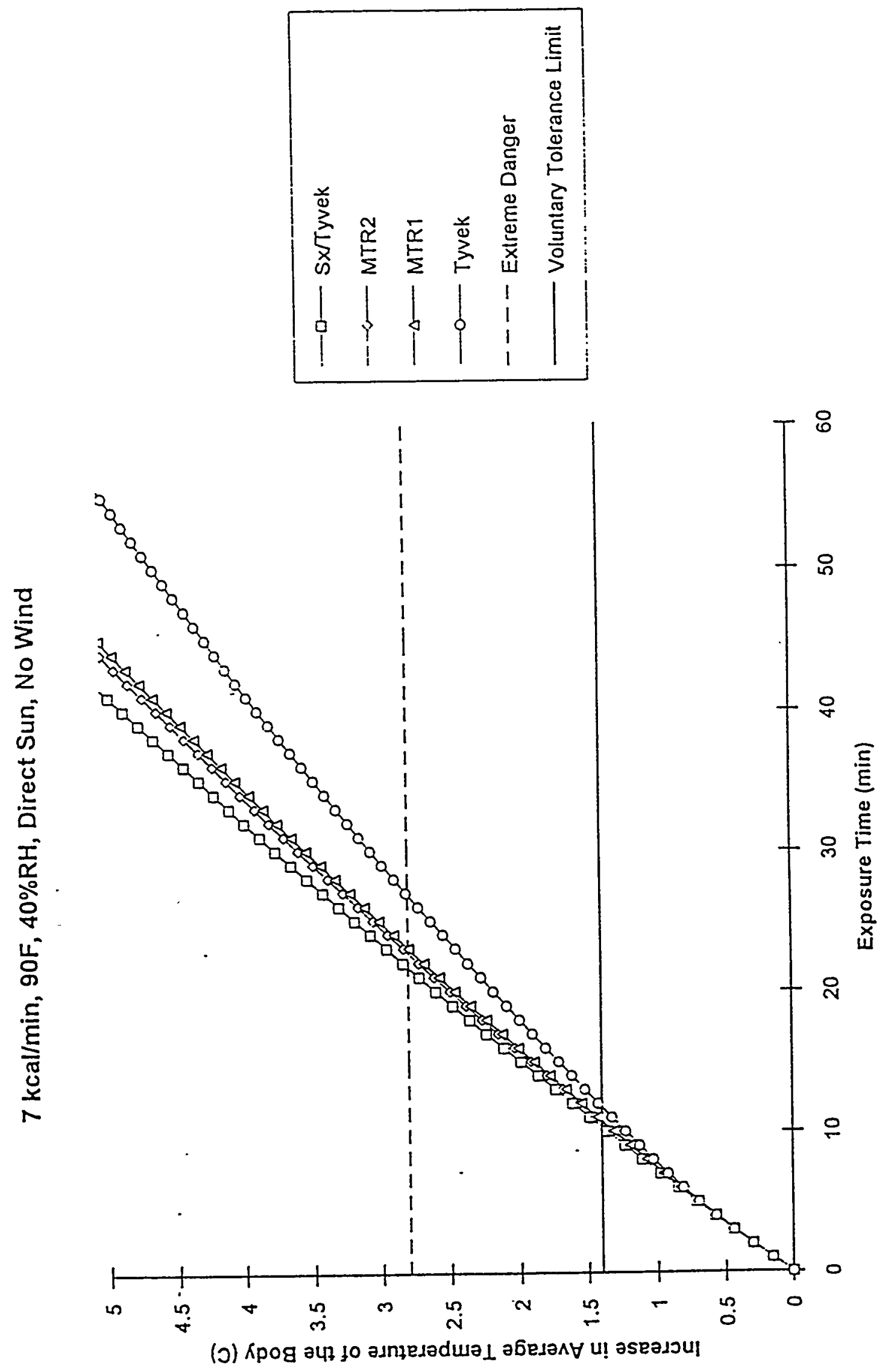


$4 \mathrm{kcal} / \mathrm{min}, 90 \mathrm{~F}, 90 \% \mathrm{RH}$, Direct Sun, No Wind

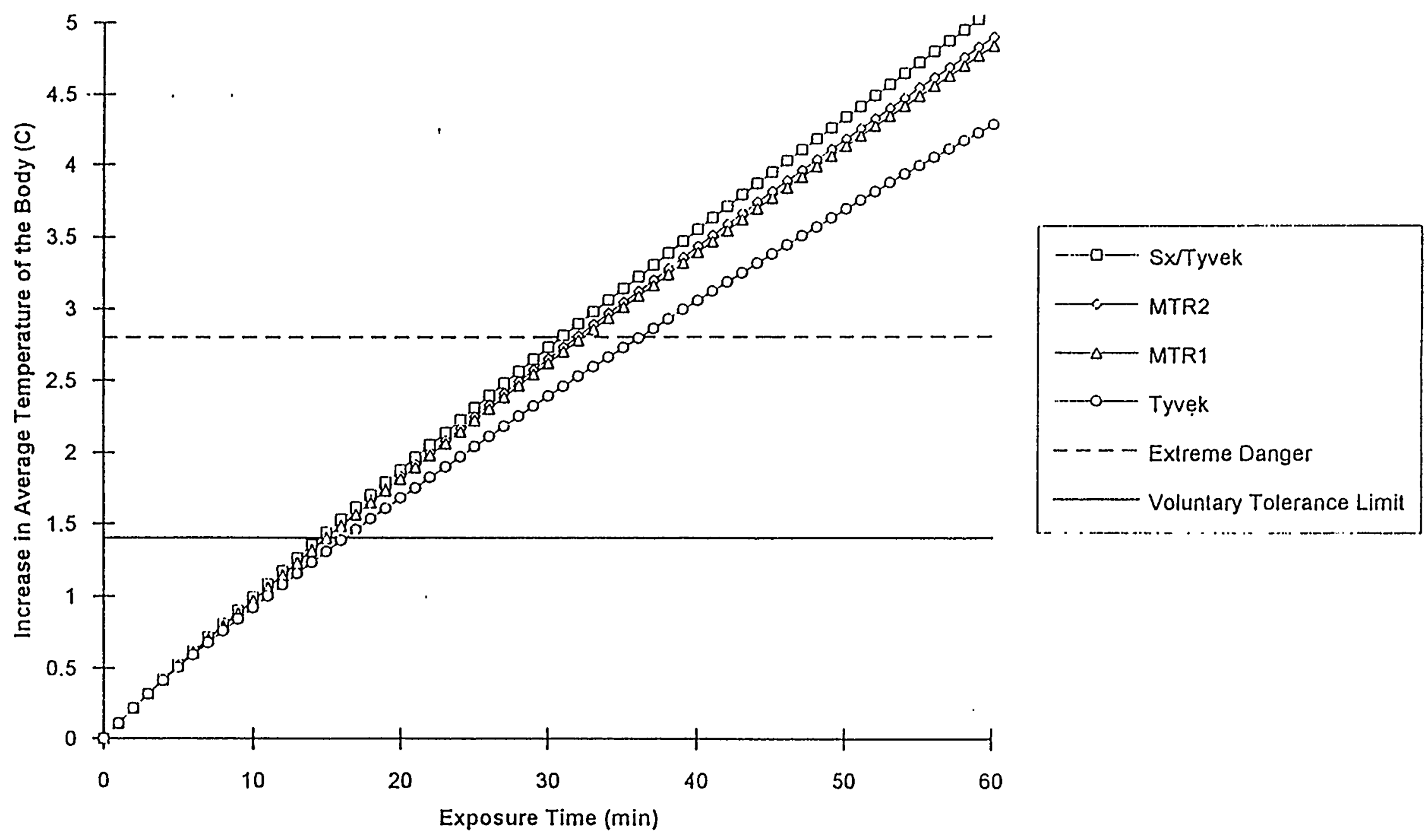




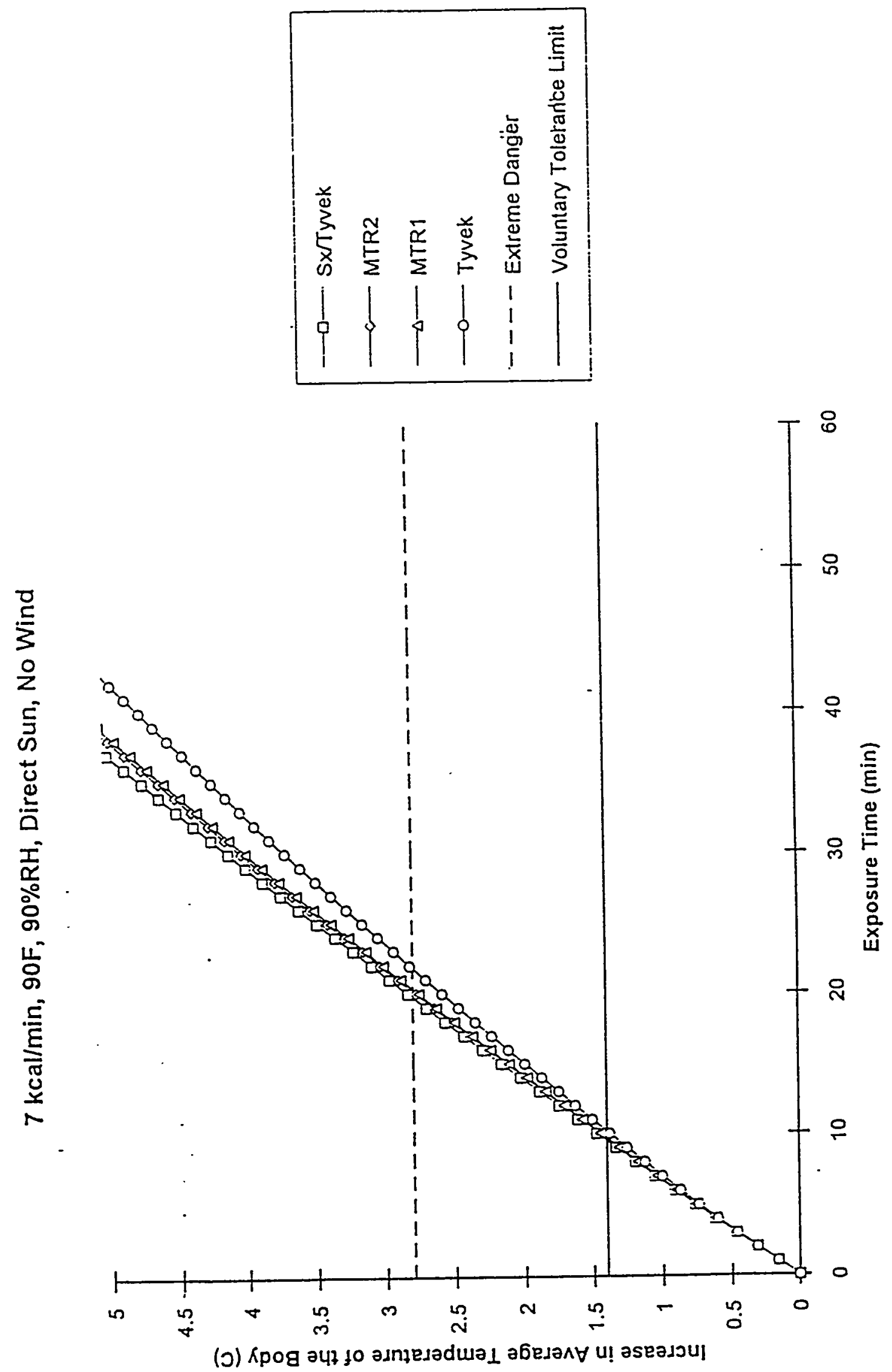




\section{References for Additional Information on Model}

B.W. Jones, Q. He, J.M. Sipes, and E.A. McCullough, "The Transient Nature of Thermal Loads Generated by People," ASHRAE Transactions, Vol. 100, Part. 2, 1994.

B.W. Jones and Y. Ogawa, "Transient Response of the Human-Clothing System, Journal of Thermal Biology, Vol. 18, No. 5/6, 1993.

B.W. Jones and Y. Ogawa, "Transient Interaction Between the Human Body and the Thermal Environment," ASHRAE Transactions, Vol. 98, Part. 1, 1992.

E.A. McCullough, B.W. Jones, and T. Tamura, "A Data Base for Determining the Evaporative Resistance of Clothing," ASHRAE Transactions, Vol. 95, Part 2, 1989. 